\title{
Biomimetic Interaction of Proteins with Functionalized Nanoparticles: A Thermodynamic Study
}

Mrinmoy De, Chang-Cheng You, Sudhanshu Srivastava and Vincent M. Rotello*

Department of Chemistry, University of Massachusetts, 710 North Pleasant Street, Amherst, MA 01003

Transmission Electron Microscopy (TEM): The nanoparticle film was drop-cast by putting a drop of aqueous nanoparticles on a 300 mesh carbon-coated copper grid. The solvent was evaporated at room temperature (ca. $20^{\circ} \mathrm{C}$ ). The TEM images were taken on a JEOL 200 instrument operated at $200 \mathrm{keV}$ (Figure S1).

Thermogravimetric analysis (TGA): TGA was performed using a TGA 2950 high-resolution thermo-gravimetric analyzer (TA Instruments, Inc., New Castle, DE), which was equipped with an open platinum pan and an automatically programmed temperature controller. The TGA curves were recorded as follows: about $3.5 \mathrm{mg}$ of nanoparticles was placed in the TGA pan and heated in a nitrogen atmosphere at a rate of $10^{\circ} \mathrm{C} / \min$ up to $600^{\circ} \mathrm{C}$. 
(a)
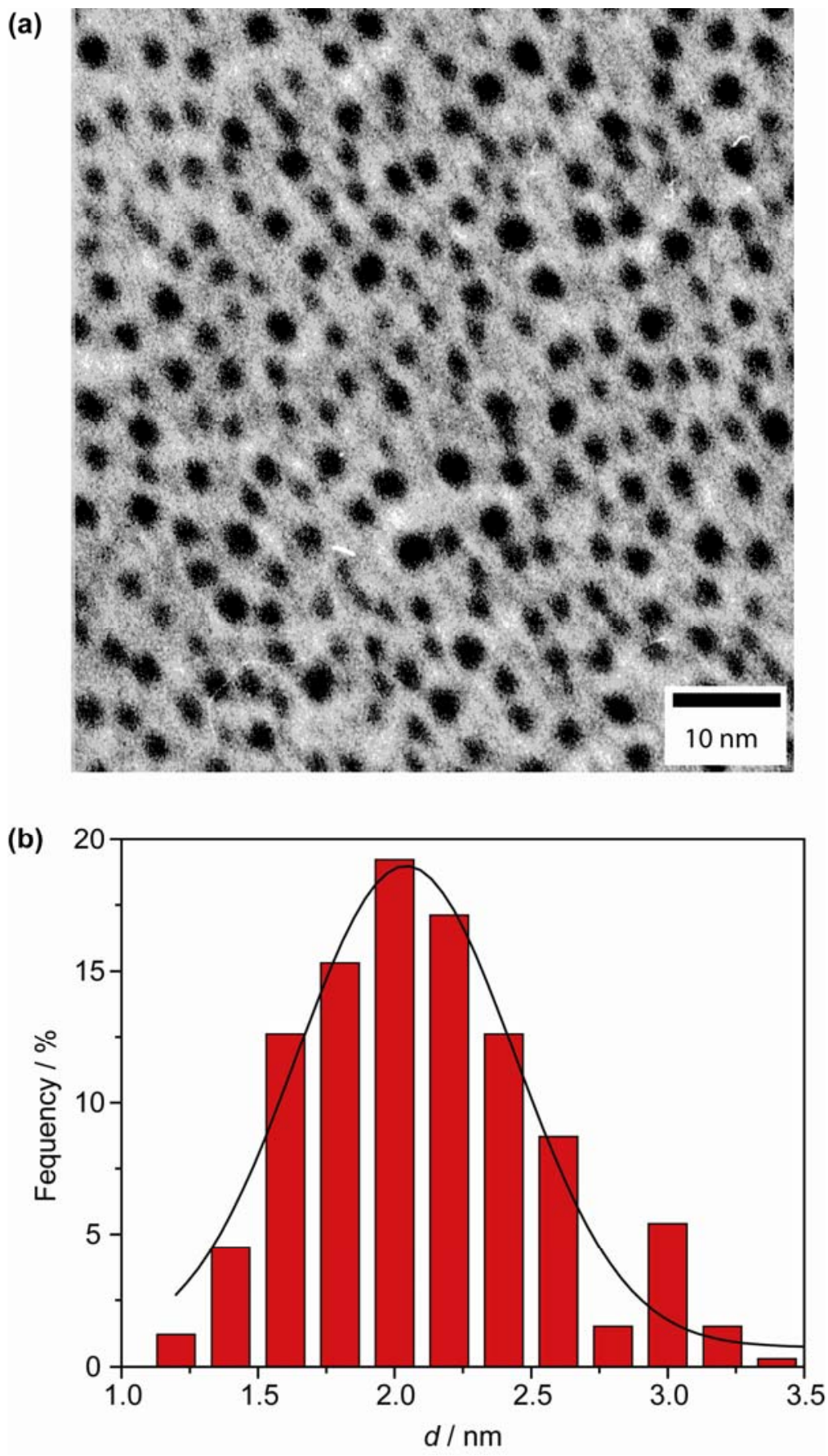

Figure S1. (a) Transmission electron microscopic (TEM) image of NP_Ala. (b) Histogram of size distribution of NP_Ala (333 counts). The average diameter is $2.1 \pm 0.4 \mathrm{~nm}$. 


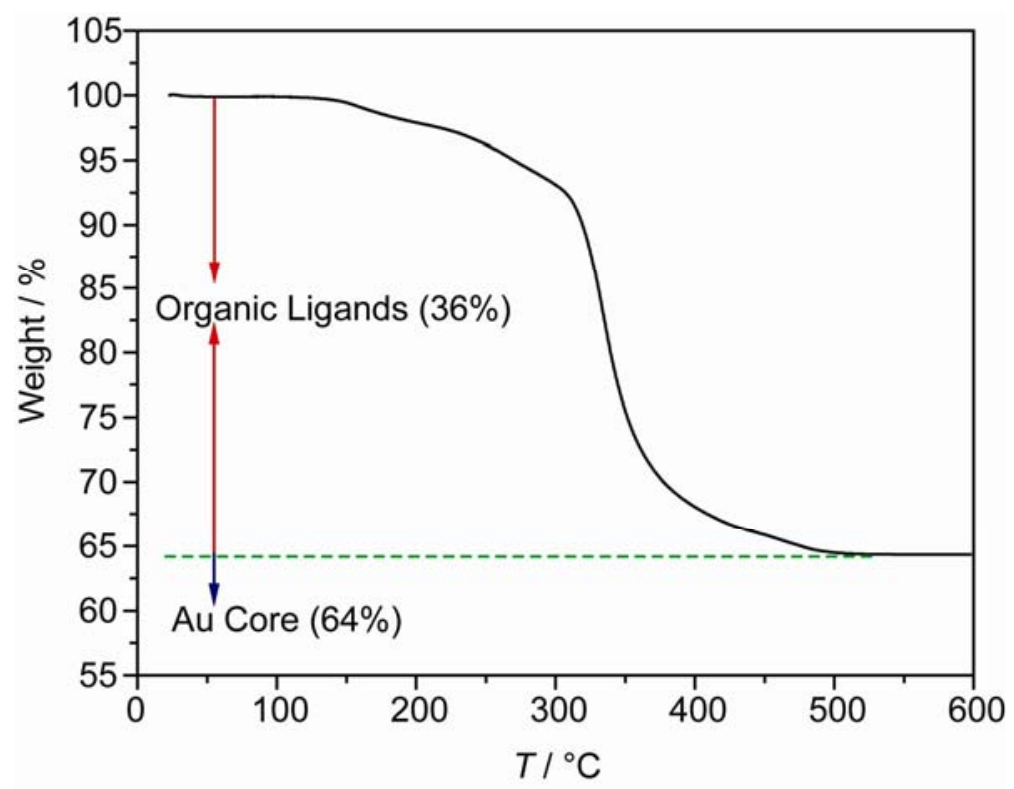

Figure S2. Thermal gravimetric analysis (TGA) curve of NP_Ala.

\section{Isothermal Titration Calorimetry}

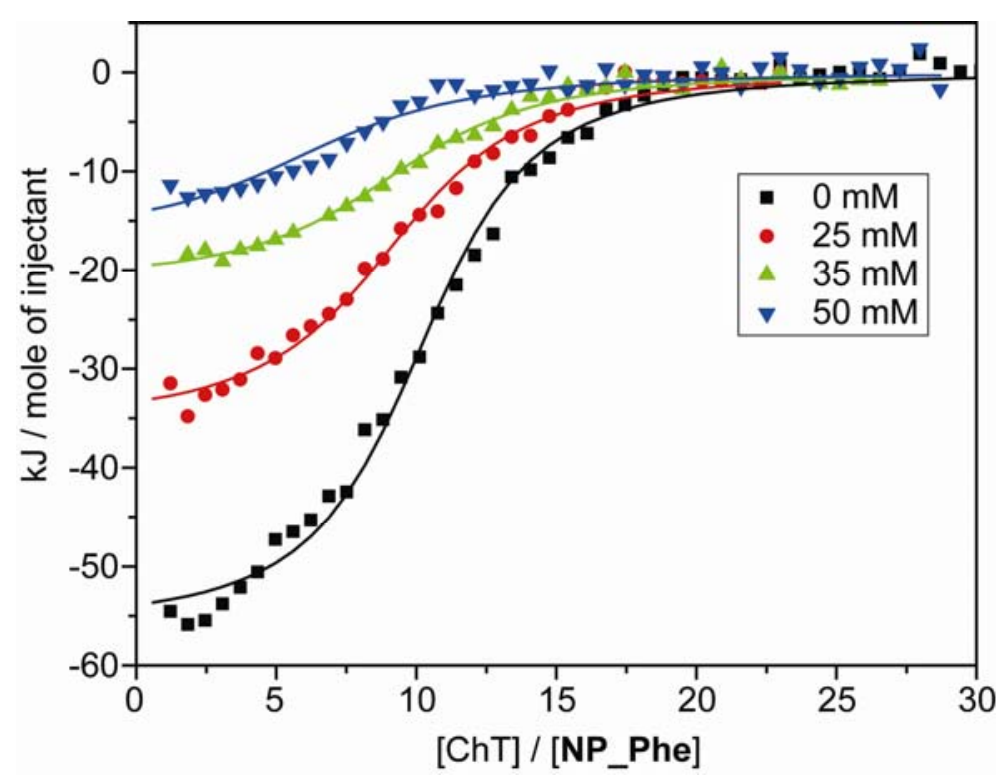

Figure S3. ITC analysis of the interaction of ChT with phenylalanine-functionalized nanoparticles in $5 \mathrm{mM}$ sodium phosphate buffer $(\mathrm{pH}=7.4)$ at various $\mathrm{NaCl}$ concentrations. The initial concentrations of NP_Phe and ChT were 2.5 $\mu \mathrm{M}$ and $350 \mu \mathrm{M}$, respectively. 


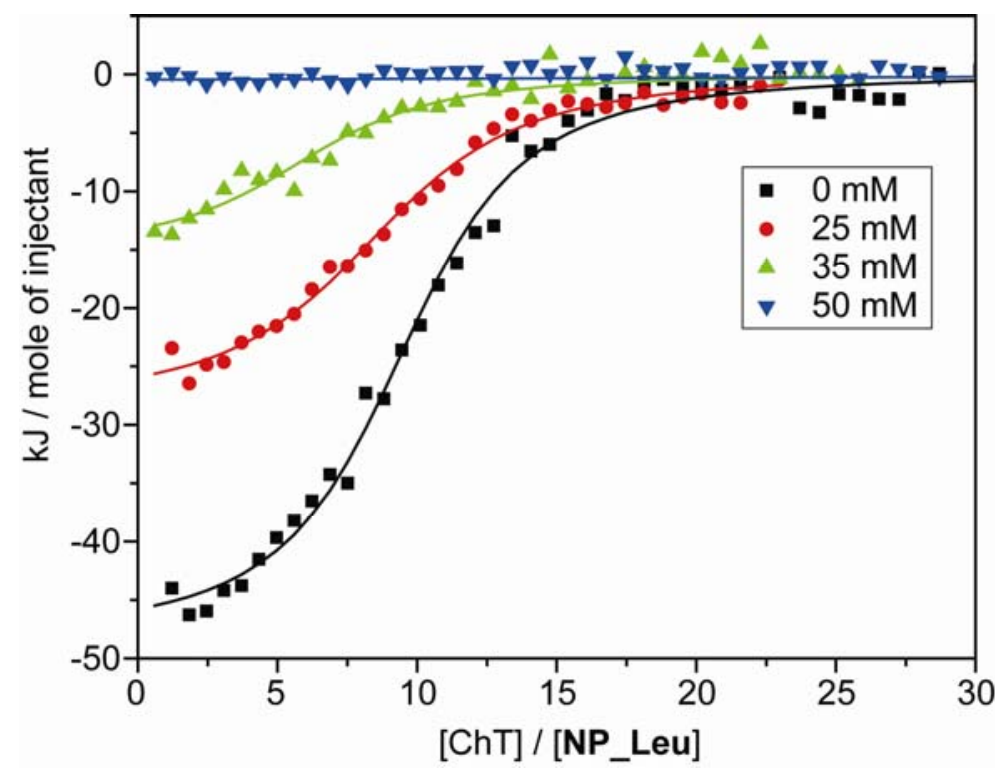

Figure S4. ITC analysis of the interaction of ChT with leucine-functionalized NPs in $5 \mathrm{mM}$ sodium phosphate buffer $(\mathrm{pH}=7.4)$ at various $\mathrm{NaCl}$ concentrations. The initial concentrations of NP_Leu and ChT were $2.5 \mu \mathrm{M}$ and $350 \mu \mathrm{M}$, respectively.

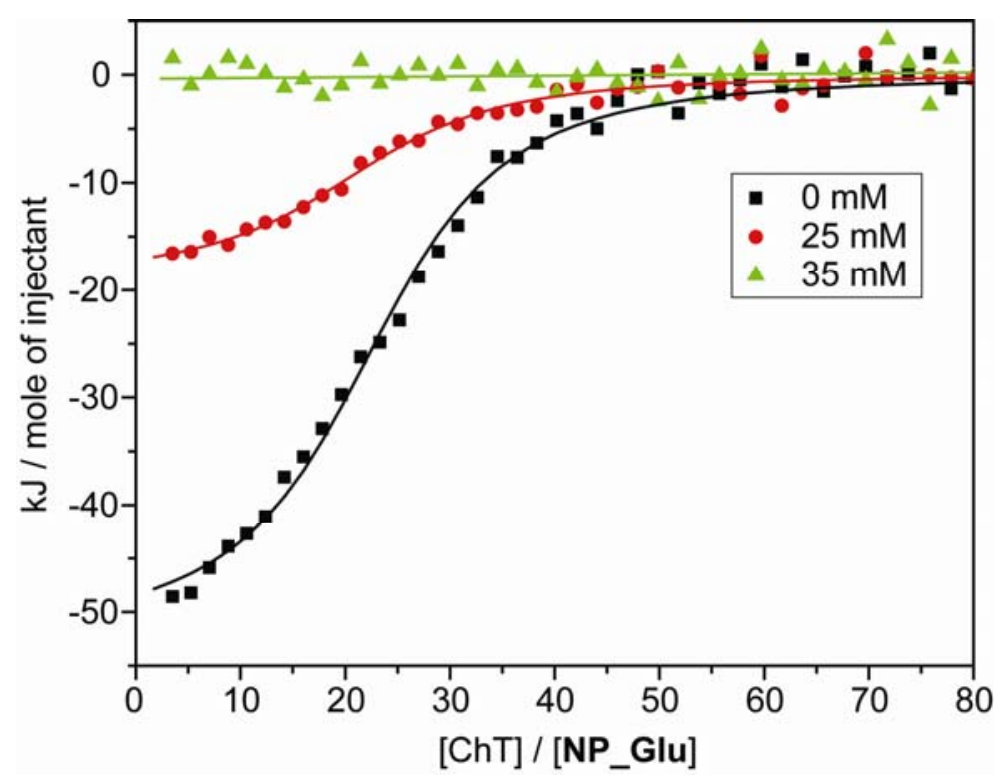

Figure S5. ITC analysis of the interaction of ChT with glutamic acid-functionalized nanoparticles in $5 \mathrm{mM}$ sodium phosphate buffer $(\mathrm{pH}=7.4)$ at various $\mathrm{NaCl}$ concentrations. The initial concentrations of NP_Glu and ChT were 1.0 $\mu \mathrm{M}$ and $400 \mu \mathrm{M}$, respectively. 


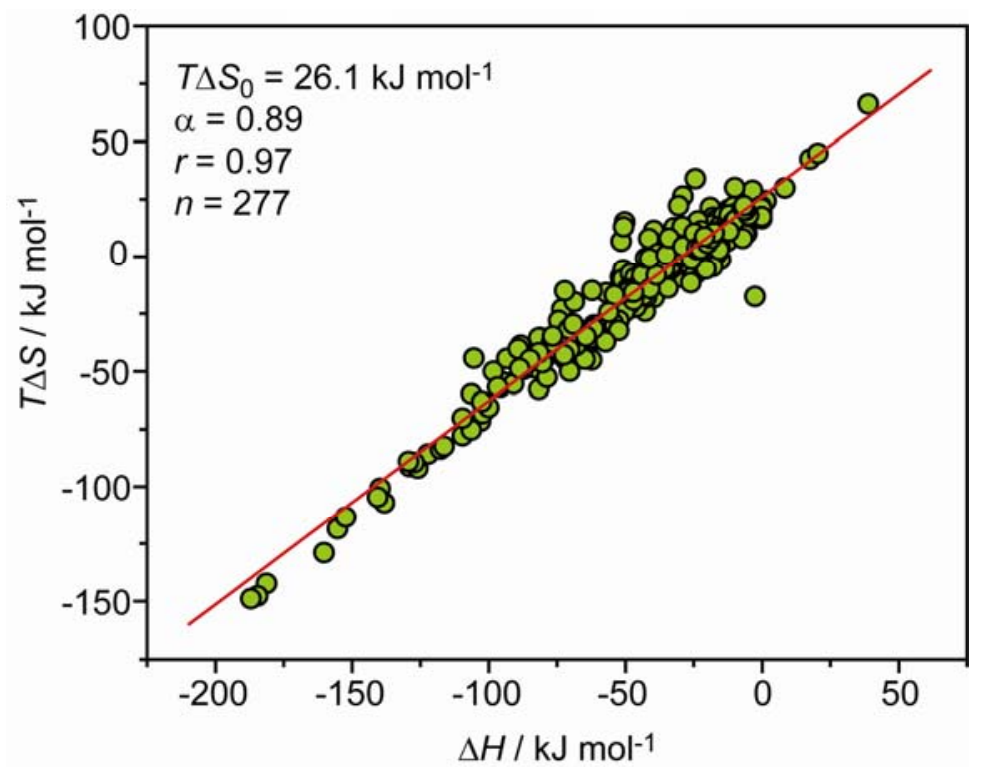

Figure S6. Plots of entropy $(T \Delta S)$ versus enthalpy $(\Delta H)$ for the protein-ligand (nonpeptide) interactions.

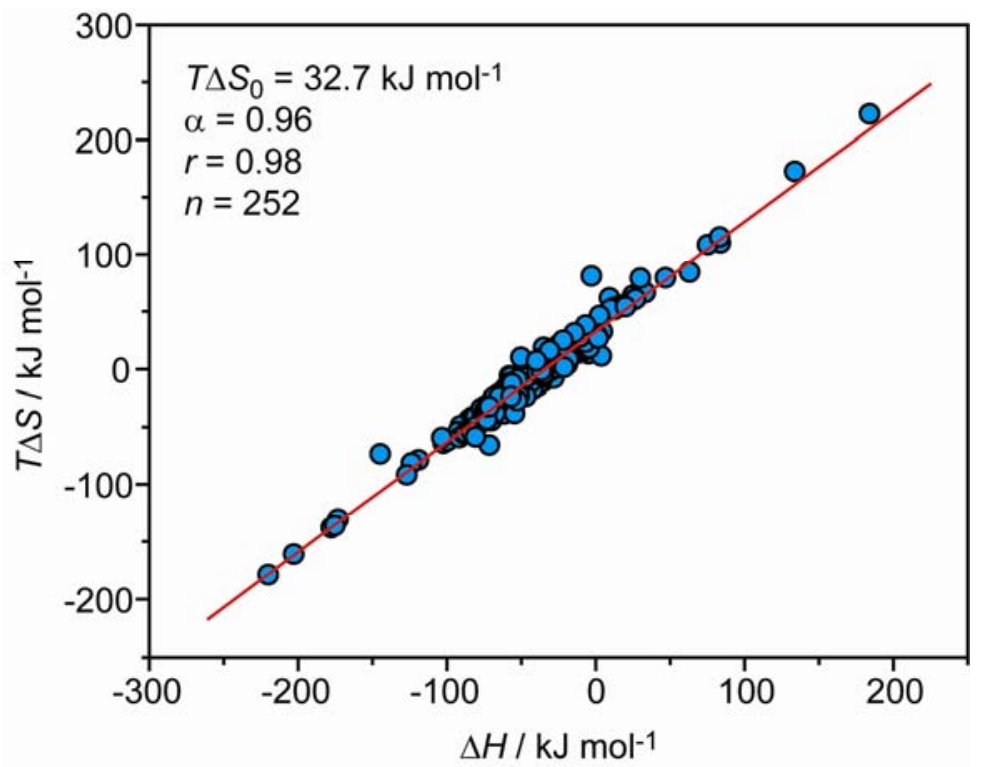

Figure S7. Plots of entropy $(T \Delta S)$ versus enthalpy $(\Delta H)$ for the protein-peptide interactions. 
Table S1. Thermodynamic Parameters for the Complexation of ChT with Different Amino Acid-Functionalized NPs in Various Phosphate Buffered $\mathrm{NaCl}$ Solutions (5 mM Sodium Phosphate, $\mathrm{pH} 7.4)$ at $30^{\circ} \mathrm{C}$.

\begin{tabular}{|c|c|c|c|c|c|c|}
\hline NP & Salt conc. & $K_{\mathrm{S}} / 10^{5} \mathrm{M}^{-1}$ & $\Delta G / \mathrm{kJ} \mathrm{mol}^{-1}$ & $\Delta H / \mathrm{kJ} \mathrm{mol}^{-1}$ & $\Delta S / \mathrm{J} \mathrm{mol}^{-1} \mathrm{~K}^{-1}$ & $n$ \\
\hline \multirow{4}{*}{ NP_L-Phe } & 0 & 8.6 & -34.4 & -56.2 & -71.5 & 10.2 \\
\hline & 25 & 6.3 & -33.7 & -35.2 & -5.7 & 9.5 \\
\hline & 35 & 4.2 & -32.7 & -22.8 & 32.4 & 9.5 \\
\hline & 50 & 2.0 & -30.8 & -17.8 & 43.1 & 8.2 \\
\hline \multirow{4}{*}{ NP_L-Leu } & 0 & 7.8 & -34.2 & -48.1 & -46.0 & 9.7 \\
\hline & 25 & 4.8 & -32.9 & -28.2 & 15.6 & 9.0 \\
\hline & 35 & 1.9 & -30.7 & -17.7 & 43.1 & 6.9 \\
\hline & 50 & \multicolumn{5}{|c|}{$\mathrm{ND}^{a}$} \\
\hline \multirow{3}{*}{ NP_L-Glu } & 0 & 5.2 & -33.2 & -52.1 & -62.3 & 23.6 \\
\hline & 25 & 2.8 & -31.6 & -21.7 & 32.8 & 22.4 \\
\hline & 35 & \multicolumn{5}{|c|}{$\mathrm{ND}^{a}$} \\
\hline NP_L-Gly & 0 & 3.6 & -32.2 & -38.7 & -21.2 & 7.3 \\
\hline
\end{tabular}

${ }^{a}$ Not detectable 
Table S2. Thermodynamic Parameters for Some Protein-Protein Interactions.

\begin{tabular}{|c|c|c|c|c|c|c|}
\hline Complex & Solvent & $\begin{array}{ll}T & / \\
{ }^{\circ} \mathrm{C} & \\
\end{array}$ & $\begin{array}{l}\Delta G / \\
\mathrm{kJ} \mathrm{mol}^{-1}\end{array}$ & $\begin{array}{l}\Delta H / \\
\mathrm{kJ} \mathrm{mol}\end{array}$ & $\begin{array}{l}T \Delta S / \\
\mathrm{kJ} \mathrm{mol}^{-1}\end{array}$ & Ref \\
\hline Trypsin/soybean inhibitor & $200 \mathrm{mM} \mathrm{KCl}, 50 \mathrm{mM} \mathrm{CaCl}_{2}$, pH 5.0 & 25.0 & -51.5 & 36.0 & 87.1 & 1 \\
\hline Trypsin/cleaved soybean inhibitor & $200 \mathrm{mM} \mathrm{KCl}, 50 \mathrm{mM} \mathrm{CaCl}_{2}$, pH 5.0 & 25.0 & -45.2 & 52.7 & 98.0 & 1 \\
\hline Trypsin/ovomucoid & $200 \mathrm{mM} \mathrm{KCl}, 50 \mathrm{mM} \mathrm{CaCl}_{2}$, pH 5.0 & 25.0 & -42.7 & 23.4 & 66.2 & 1 \\
\hline Trypsin/lima bean inhibitor & $200 \mathrm{mM} \mathrm{KCl}, 50 \mathrm{mM} \mathrm{CaCl}_{2}$, pH 5.0 & 25.0 & -53.1 & 8.8 & 62.0 & 1 \\
\hline Chymotrypsin/bovine pancreatic trypsin inhibitor & $50 \mathrm{mM}$ Tris $/ \mathrm{HCl}, 20 \mathrm{mM} \mathrm{CaCl}_{2}, 0.005 \%$ Triton X-100, $\mathrm{pH} 8.2$ & 22.0 & -44.8 & 10.5 & 55.2 & 2 \\
\hline Chymotrypsin/subtilisin inhibitor & $25 \mathrm{mM}$ potassium phosphate, ionic strength $=100 \mathrm{mM}$ with $\mathrm{KCl}, \mathrm{pH} 7.0$ & 25.0 & -29.9 & 18.7 & 47.7 & 3 \\
\hline Chymotrypsin/OMTKY3 & $50 \mathrm{mM}$ acetic acid/sodium acetate, $20 \mathrm{mM} \mathrm{NaCl}, \mathrm{pH} 4.5$ & 25.0 & -39.3 & 52.3 & 91.6 & 4 \\
\hline Subtilisin/subtilisin inhibitor & $25 \mathrm{mM}$ potassium phosphate, ionic strength $=100 \mathrm{mM}$ with $\mathrm{KCl}, \mathrm{pH} 7.0$ & 25.0 & -57.9 & -19.8 & 38.1 & 5 \\
\hline Calmodulin $\mathrm{Ca}^{2+} /$ myosin light chain kinase & $50 \mathrm{mM}$ Pipes/NaOH, $150 \mathrm{mM} \mathrm{NaCl}, 0.5 \mathrm{mM} \mathrm{CaCl}_{2}, \mathrm{pH} 7.5$ & 25.0 & -48.1 & -84.9 & -36.4 & 6 \\
\hline Calmodulin $\mathrm{Ca}^{2+} /$ seminal plasmin & $50 \mathrm{mM}$ Pipes/NaOH, $150 \mathrm{mM} \mathrm{NaCl}, 0.5 \mathrm{mM} \mathrm{CaCl}_{2}, \mathrm{pH} 7.5$ & 25.0 & -50.2 & -50.2 & 0 & 6 \\
\hline Calmodulin/myosin light chain kinase & $50 \mathrm{mM}$ Pipes/NaOH, $150 \mathrm{mM} \mathrm{NaCl}, \mathrm{pH} 7.5$ & 25.0 & -30.1 & 0 & 30.1 & 6 \\
\hline Calmodulin/seminal plasmin & $50 \mathrm{mM}$ Pipes/NaOH, $150 \mathrm{mM} \mathrm{NaCl}, \mathrm{pH} 7.5$ & 25.0 & -33.9 & 0 & 33.9 & 6 \\
\hline Ch4D5 Fab/p185 ${ }^{\text {HER2-ECD }}$ & $20 \mathrm{mM}$ sodium phosphate, $100 \mathrm{mM} \mathrm{NaCl}, \mathrm{pH} 7.5$ & 25.0 & -56.5 & -72.0 & -15.0 & 7 \\
\hline HyHEL-5/hen egg lysozyme & $10 \mathrm{mM}$ sodium phosphate, $\mathrm{pH} 8.0$ & 25.0 & -60.7 & -94.6 & -33.9 & 8 \\
\hline HyHEL-10/hen egg lysozyme & $50 \mathrm{mM}$ phosphate, $200 \mathrm{mM} \mathrm{NaCl}, \mathrm{pH} 7.2$ & 30.0 & -50.2 & -91.6 & -41.4 & 9 \\
\hline HyHEL-10/hen egg lysozyme & $50 \mathrm{mM}$ phosphate, $200 \mathrm{mM} \mathrm{NaCl}$, $\mathrm{pH} 7.2$ & 30.0 & -51.7 & -99.7 & -47.9 & 10 \\
\hline Fv D1.3/hen egg lysozyme & $10 \mathrm{mM}$ sodium phosphate, $150 \mathrm{mM} \mathrm{NaCl}, \mathrm{pH} 7.1$ & 49.8 & -42.6 & -129.0 & -86.0 & 11 \\
\hline mAb D1.3/hen egg lysozyme & $10 \mathrm{mM}$ sodium phosphate, $150 \mathrm{mM} \mathrm{NaCl}, \mathrm{pH} 7.1$ & 24.2 & -48.0 & -90.8 & -42.8 & 11 \\
\hline F9.13.7/hen egg lysozyme & $10 \mathrm{mM}$ sodium phosphate, $150 \mathrm{mM} \mathrm{NaCl}, \mathrm{pH} 7.1$ & 23.9 & -50.2 & -46.4 & 4.1 & 12 \\
\hline $\mathrm{D} 44.1 /$ hen egg lysozyme & $10 \mathrm{mM}$ sodium phosphate, $150 \mathrm{mM} \mathrm{NaCl}, \mathrm{pH} 7.1$ & 24.2 & -40.6 & -43.1 & -2.9 & 12 \\
\hline D11.15/hen egg lysozyme & $10 \mathrm{mM}$ sodium phosphate, $150 \mathrm{mM} \mathrm{NaCl}, \mathrm{pH} 7.1$ & 24.9 & -50.6 & -79.5 & -28.7 & 12 \\
\hline D1.3/E5.2 & $10 \mathrm{mM}$ sodium phosphate, $150 \mathrm{mM} \mathrm{NaCl}, \mathrm{pH} 7.1$ & 25.0 & -43.5 & -279.1 & -235.0 & 13 \\
\hline D1.3/E225 & $10 \mathrm{mM}$ sodium phosphate, $150 \mathrm{mM} \mathrm{NaCl}, \mathrm{pH} 7.1$ & 28.3 & -30.5 & 7.5 & 38.3 & 13 \\
\hline Ferredoxin/ferredoxin :NADP ${ }^{+ \text {reductase }}$ & $50 \mathrm{mM}$ Tris/HCl, $\mathrm{pH} 7.5$ & 27.0 & -39.1 & -1.3 & 37.8 & 14 \\
\hline Colicin N/OmpF & $20 \mathrm{mM}$ Tris, $300 \mathrm{mM} \mathrm{NaCl}, 1 \%$ octyl-polyoxyethylene, $\mathrm{pH} 7.4$ & 25.0 & -32.4 & -51.5 & -19.1 & 15 \\
\hline Colicin N/OmpC & $20 \mathrm{mM}$ Tris, $300 \mathrm{mM} \mathrm{NaCl}, 1 \%$ octyl-polyoxyethylene, $\mathrm{pH} 7.4$ & 25.0 & -29.5 & -15.5 & 14.0 & 15 \\
\hline Colicin N/PhoE & $20 \mathrm{mM}$ Tris, $300 \mathrm{mM} \mathrm{NaCl}, 1 \%$ octyl-polyoxyethylene, $\mathrm{pH} 7.4$ & 25.0 & -30.8 & -25.0 & 5.9 & 15 \\
\hline Barstar/barnase & 50 mM Pipes, $\mathrm{pH} 7.0$ & 25.0 & -73.2 & -58.0 & 15.2 & 16 \\
\hline Human tissue factor/coagulation factor VII & $20 \mathrm{mM}$ Tris/HCl, $100 \mathrm{mM} \mathrm{NaCl}, 5 \mathrm{mM} \mathrm{CaCl}$, $\mathrm{pH} 7.5$ & 25.0 & -46.9 & -133.9 & -87.3 & 17 \\
\hline Cytochrome $c /$ cytochrome $c$ peroxidase & $50 \mathrm{mM}$ ionic strength, potessium phosphate $/ \mathrm{KNO}_{3}, \mathrm{pH} 6.0$ & 26.0 & -29.1 & 9.6 & 38.8 & 18 \\
\hline Cytochrome $c /$ cytochrome $c$ peroxidase & $50 \mathrm{mM}$ DMG, $\mathrm{pH} 6.0$ & 25.0 & -32.2 & -9.6 & 22.2 & 19 \\
\hline Cytochrome $c /$ cytochrome $c$ peroxidase, site 1 & 50 mM DMG, 200 mM melezitose, pH 6.0 & 25.0 & -41.8 & -15.5 & 26.3 & 19 \\
\hline Cytochrome $c /$ cytochrome $c$ peroxidase, site 2 & 50 mM DMG, 200 mM melezitose, $\mathrm{pH} 6.0$ & 25.0 & -33.5 & -2.5 & 31.0 & 19 \\
\hline Cytochrome $c /$ cytochrome $b 5$ & $2 \mathrm{mM}$ Tris/HCl, $\mathrm{pH} 7.4$ & 25.0 & -38.1 & 4.2 & 42.3 & 20 \\
\hline Cytochrome $c / \mathrm{Ab}$ E3 & $20 \mathrm{mM}$ sodium/potassium phosphate, $0.8 \% \mathrm{NaCl}, 0.02 \% \mathrm{KCl}, \mathrm{pH} 7.2$ & 25.0 & -40.6 & -30.5 & 11.0 & 21 \\
\hline Cytochrome $c / \mathrm{Ab} \mathrm{E} 8$ & $20 \mathrm{mM}$ sodium/potassium phosphate, $0.8 \% \mathrm{NaCl}, 0.02 \% \mathrm{KCl}, \mathrm{pH} 7.2$ & 25.0 & -39.7 & -39.7 & 0.4 & 21 \\
\hline Cytochrome $c / \mathrm{MAb} 2 \mathrm{~B} 5$ & $100 \mathrm{mM}$ sodium phosphate, $\mathrm{pH} 7.0$ & 25.0 & -52.7 & -87.9 & -35.2 & 22 \\
\hline Cytochrome $c / \mathrm{MAb} 5 \mathrm{~F} 8$ & $100 \mathrm{mM}$ sodium phosphate, $\mathrm{pH} 7.0$ & 25.0 & -58.2 & -90.8 & -32.8 & 22 \\
\hline $\mathrm{CheY} / \mathrm{CheA}_{1-233}$ & $\begin{array}{l}20 \mathrm{mM} \text { sodium phosphate, } 20 \mathrm{mM} \mathrm{NaCl}, 1 \mathrm{mM} \text { EDTA, } 1 \mathrm{mM} \\
\text { PMSF, } 10 \%(\mathrm{v} / \mathrm{v}) \text { glycerol, } \mathrm{pH} 7.4\end{array}$ & 28.0 & -33.9 & -51.9 & -18.1 & 23 \\
\hline $\mathrm{CheB} / \mathrm{CheA}_{1-233}$ & $20 \mathrm{mM}$ sodium phosphate, $20 \mathrm{mM} \mathrm{NaCl}, 1 \mathrm{mM}$ EDTA, $1 \mathrm{mM}$ & 28.0 & -31.4 & -42.3 & -11.0 & 23 \\
\hline
\end{tabular}


Interleukin 5-IL5 receptor $\alpha$ subunit Erythropoietin/EPO receptor site 1

Erythropoietin/EPO receptor site 2 Human growth hormone G120R/hGHbp Phosphocarrier protein/enzyme I N-domain Stem cell factor/Kit extracellular domain Hck SH3 domain/HIV-1 Nef Fyn SH3 domain/PI3-Kinase p85 subunit Elastase/ovomucoid third domain

Chaperonin GroEL/reduced $\alpha$-lactalbumin Chaperonin GroEL/reduced $\alpha$-lactalbumin Champeronin GroEL/denatured pepsin

Glycoprotein gp120/CD4

Dihydrolipoyl dehydrogenase/PSBD of E2 Human factor X/NAPc2

Human factor Xa/NAPc2

$\mathrm{CBF} \beta$ protein/Runx 1 Runt domain

$\mathrm{CBF} \beta-\mathrm{SMMHC}_{47}$ protein/Runx 1 Runt domain

A. niger xylanase/xylanase-inhibiting protein I

$\alpha$-Hemoglobin stabilizing protein/ $\alpha$-globin

$\beta$-Lactoglobulin/pectin, site 1

$\beta$-Lactoglobulin/pectin, site 2

$\alpha$-Amylase 2/BASI

$\alpha$-Amylase 2/BASI

Thrombin/monoclonal antibody

Xanthine oxidase/Cu, Zn-SOD

Human growth hormone/hGHR ECD

E colicin DNase E2/immunity protein Im2

E colicin DNase E7/immunity protein $\operatorname{Im} 9$

E colicin DNase E9/immunity protein Im9
PMSF, 10\% (v/v) glycerol, $\mathrm{pH} 7.4$

$20 \mathrm{mM}$ potassium phosphate, $150 \mathrm{mM} \mathrm{NaCl}, \mathrm{pH} 7.4$

Dulbecco's phosphate buffered saline, $\mathrm{pH} 7.0$

Dulbecco's phosphate buffered saline, $\mathrm{pH} 7.0$

$10 \mathrm{mM}$ sodium phosphate, $137 \mathrm{mM} \mathrm{NaCl}, 2.7 \mathrm{mM} \mathrm{KCl}, \mathrm{pH} 7.2$

$10 \mathrm{mM}$ potassium phosphate, $100 \mathrm{mM} \mathrm{KCl}, 1 \mathrm{mM}$ EDTA, $\mathrm{pH} 7.5$

Phosphate buffered saline

50 mM HEPES, $150 \mathrm{mM} \mathrm{NaCl}, 3.4$ mM EDTA, 2 mM DTT, pH 7.4

$10 \mathrm{mM}$ phosphate, $\mathrm{pH} 6.0$

$50 \mathrm{mM}$ imidazole chloride, $\mathrm{pH} 7.0$

$25 \mathrm{mM}$ Tris/HCl, $200 \mathrm{mM} \mathrm{KCl}, 1 \mathrm{mM}$ DTT, $1 \mathrm{mM}$ EDTA, pH 7.8

$25 \mathrm{mM}$ Tris/HCl, $1 \mathrm{mM}$ DTT, $1 \mathrm{mM}$ EDTA, $\mathrm{pH} 7.8$

$25 \mathrm{mM}$ Tris/HCl, $200 \mathrm{mM} \mathrm{KCl,} 1 \mathrm{mM}$ DTT, $1 \mathrm{mM}$ EDTA, pH 7.8

$3 \mathrm{mM}$ sodium phosphate, $100 \mathrm{mM} \mathrm{NaCl}, \mathrm{pH} 7.4$

$10 \mathrm{mM}$ HEPES, $150 \mathrm{mM} \mathrm{NaCl}, 3.4 \mathrm{mM}$ EDTA, pH 7.4

$20 \mathrm{mM}$ HEPES, $150 \mathrm{mM} \mathrm{NaCl}, 2 \mathrm{mM} \mathrm{Ca}^{2+}$, pH 7.4

$20 \mathrm{mM}$ HEPES, $150 \mathrm{mM} \mathrm{NaCl}, 2 \mathrm{mM} \mathrm{Ca}{ }^{2+}, \mathrm{pH} 7.4$

McIlvaine buffer, $\mathrm{pH} 5.5$

$20 \mathrm{mM}$ sodium phosphate buffer, $150 \mathrm{mM} \mathrm{NaCl}, \mathrm{pH} 7.0$

$5 \mathrm{mM}$ sodium phosphate, $\mathrm{pH} 4.0$

$5 \mathrm{mM}$ sodium phosphate, $\mathrm{pH} 4.0$

$40 \mathrm{mM}$ HEPES, $200 \mathrm{mM} \mathrm{NaCl}, 5 \mathrm{mM} \mathrm{CaCl}_{2}$, $\mathrm{pH} 6.8$

$40 \mathrm{mM}$ sodium acetate, $5 \mathrm{mM} \mathrm{CaCl}_{2}$, pH 5.5

$25 \mathrm{mM}$ potassium phosphate, $150 \mathrm{mM} \mathrm{NaCl}$, $\mathrm{pH} 6.5$

$10 \mathrm{mM}$ HEPES, $150 \mathrm{mM} \mathrm{NaCl}, 1 \mathrm{mM}$ EDTA, pH 7.4

$20 \mathrm{mM}$ HEPES, $150 \mathrm{mM} \mathrm{NaCl}$, $\mathrm{pH} 7.4$

$50 \mathrm{mM}$ Mops, $200 \mathrm{mM} \mathrm{NaCl}, \mathrm{pH} 7.0$

$50 \mathrm{mM}$ Mops, $200 \mathrm{mM} \mathrm{NaCl}$, pH 7.0

$50 \mathrm{mM}$ Mops, $200 \mathrm{mM} \mathrm{NaCl}$, pH 7.0

\begin{tabular}{lllll}
25.0 & -48.5 & -47.7 & 0.8 & 24 \\
25.0 & -49.0 & -6.3 & 42.7 & 25 \\
25.0 & -35.1 & -14.2 & 21.0 & 25 \\
26.2 & -49.0 & -39.3 & 9.6 & 26 \\
25 & -29.3 & 36.7 & 66.0 & 27 \\
25 & -37.7 & -54.4 & -16.7 & 28 \\
25 & -38.5 & -53.6 & -15.0 & 29 \\
30 & -31.8 & 44.4 & 76.4 & 30 \\
25 & -60.7 & -4.2 & 56.5 & 31 \\
10.0 & -28.4 & 49.7 & 78.1 & 32 \\
10.5 & -31.6 & 82.2 & 113.8 & 32 \\
25.1 & -32.1 & 47.4 & 79.6 & 32 \\
37.0 & -49.4 & -263.6 & -214.2 & 33 \\
25.0 & -52.7 & 9.2 & 61.9 & 34 \\
25.0 & -51.7 & -57.8 & -6.1 & 35 \\
25.0 & -52.0 & -71.5 & -19.5 & 35 \\
30.0 & -42.2 & -18.9 & 23.3 & 36 \\
30.0 & -47.0 & -16.9 & 30.1 & 36 \\
25.0 & -42.1 & -48.5 & -6.3 & 37 \\
20.0 & -39.3 & -36.6 & 2.7 & 38 \\
22.0 & -43.5 & -52.7 & -10.5 & 39 \\
22.0 & -38.1 & -23.0 & 14.6 & 39 \\
25.0 & -45.0 & -98.0 & -53.0 & 40 \\
27.0 & -43.5 & -69.0 & -26.0 & 40 \\
25.0 & -44.8 & -34.3 & 10.5 & 41 \\
25.0 & -34.0 & -201.1 & -161.1 & 42 \\
25.0 & -51.0 & -37.6 & 13.4 & 43 \\
25.0 & -82.2 & -161.7 & -79.5 & 44 \\
25.0 & -82.8 & -237.4 & -154.4 & 44 \\
25.0 & -77.7 & -79.5 & -1.8 & 44 \\
\hline & & & &
\end{tabular}

Table S3. Thermodynamic Parameters for Some Protein-Ligand (nonpeptide) Interactions.

\begin{tabular}{|c|c|c|c|c|c|c|c|}
\hline Complex & Solvent & $\begin{array}{l}\mathrm{T} \\
{ }^{\circ} \mathrm{C} \\
\end{array}$ & I & $\begin{array}{l}\Delta G / \\
\mathrm{kJ} \mathrm{mol}^{-1}\end{array}$ & $\begin{array}{l}\Delta H / \\
\mathrm{kJ} \mathrm{mol}^{-1}\end{array}$ & $\begin{array}{l}T \Delta S / \\
\mathrm{kJ} \mathrm{mol}^{-1}\end{array}$ & Ref. \\
\hline AAC(6')-Iy/kanamycin B & $50 \mathrm{mM}$ Tris, $50 \mathrm{mM} \mathrm{NaCl}, 0.1 \% \mathrm{HS}\left(\mathrm{CH}_{2}\right)_{2} \mathrm{OH}, 0.01 \%$ Tween-80, $\mathrm{pH} 7.5$ & 27 & & -29.3 & -54.4 & -25.1 & 45 \\
\hline AAC(6')-Iy/tobramycin & $50 \mathrm{mM}$ Tris, $50 \mathrm{mM} \mathrm{NaCl}, 0.1 \% \mathrm{HS}\left(\mathrm{CH}_{2}\right)_{2} \mathrm{OH}, 0.01 \%$ Tween-80, $\mathrm{pH} 7.5$ & 27 & & -30.5 & -50.6 & -20.1 & 45 \\
\hline AAC(6')-Iy/dibekacin & $50 \mathrm{mM}$ Tris, $50 \mathrm{mM} \mathrm{NaCl}, 0.1 \% \mathrm{HS}\left(\mathrm{CH}_{2}\right)_{2} \mathrm{OH}, 0.01 \%$ Tween-80, $\mathrm{pH} 7.5$ & 27 & & -31.0 & -53.6 & -22.6 & 45 \\
\hline AAC(6')-Iy/gentamicin C & $50 \mathrm{mM}$ Tris, $50 \mathrm{mM} \mathrm{NaCl}, 0.1 \% \mathrm{HS}\left(\mathrm{CH}_{2}\right)_{2} \mathrm{OH}, 0.01 \%$ Tween-80, $\mathrm{pH} 7.5$ & 27 & & -26.8 & -33.9 & -7.1 & 45 \\
\hline AAC(6')-Iy/kanamycin A & $50 \mathrm{mM}$ Tris, $50 \mathrm{mM} \mathrm{NaCl}, 0.1 \% \mathrm{HS}\left(\mathrm{CH}_{2}\right)_{2} \mathrm{OH}, 0.01 \%$ Tween-80, $\mathrm{pH} 7.5$ & 27 & & -27.6 & -40.2 & -13.8 & 45 \\
\hline AAC(6’)-Iy/amikacin & $50 \mathrm{mM}$ Tris, $50 \mathrm{mM} \mathrm{NaCl}, 0.1 \% \mathrm{HS}\left(\mathrm{CH}_{2}\right)_{2} \mathrm{OH}, 0.01 \%$ Tween-80, $\mathrm{pH} 7.5$ & 27 & & -27.6 & -23.8 & 3.8 & 45 \\
\hline AAC(6')-Iy/sisomicin & $50 \mathrm{mM}$ Tris, $50 \mathrm{mM} \mathrm{NaCl}, 0.1 \% \mathrm{HS}\left(\mathrm{CH}_{2}\right)_{2} \mathrm{OH}, 0.01 \%$ Tween-80, $\mathrm{pH} 7.5$ & 27 & & -30.1 & -37.2 & -7.1 & 45 \\
\hline
\end{tabular}




\begin{tabular}{|c|c|c|c|c|c|c|}
\hline AAC(6')-Iy/netilmicin & $50 \mathrm{mM}$ Tris, $50 \mathrm{mM} \mathrm{NaCl}, 0.1 \% \mathrm{HS}\left(\mathrm{CH}_{2}\right)_{2} \mathrm{OH}, 0.01 \%$ Tween-80, pH 7.5 & 27 & -30.5 & -25.1 & 5.4 & 45 \\
\hline AAC(6')-Iy/ribostamycin & $50 \mathrm{mM}$ Tris, $50 \mathrm{mM} \mathrm{NaCl}, 0.1 \% \mathrm{HS}\left(\mathrm{CH}_{2}\right)_{2} \mathrm{OH}, 0.01 \%$ Tween- $80, \mathrm{pH} 7.5$ & 27 & -34.7 & -83.3 & -48.5 & 45 \\
\hline AAC(6')-Iy/butirosin & $50 \mathrm{mM}$ Tris, $50 \mathrm{mM} \mathrm{NaCl}, 0.1 \% \mathrm{HS}\left(\mathrm{CH}_{2}\right)_{2} \mathrm{OH}, 0.01 \%$ Tween-80, pH 7.5 & 27 & -33.9 & -52.7 & -18.8 & 45 \\
\hline AAC(6')-Iy/neomycin B & $50 \mathrm{mM}$ Tris, $50 \mathrm{mM} \mathrm{NaCl}, 0.1 \% \mathrm{HS}\left(\mathrm{CH}_{2}\right)_{2} \mathrm{OH}, 0.01 \%$ Tween-80, pH 7.5 & 27 & -31.4 & -61.5 & -30.1 & 45 \\
\hline AAC(6')-Iy/paromomycin & $50 \mathrm{mM}$ Tris, $50 \mathrm{mM} \mathrm{NaCl}, 0.1 \% \mathrm{HS}\left(\mathrm{CH}_{2}\right)_{2} \mathrm{OH}, 0.01 \%$ Tween- 80 , pH 7.5 & 27 & -28.5 & -31.4 & -2.9 & 45 \\
\hline AAC(6')-Iy/lividomycin A & $50 \mathrm{mM}$ Tris, $50 \mathrm{mM} \mathrm{NaCl}, 0.1 \% \mathrm{HS}\left(\mathrm{CH}_{2}\right)_{2} \mathrm{OH}, 0.01 \%$ Tween- 80 , pH 7.5 & 27 & -30.5 & -44.4 & -8.8 & 45 \\
\hline Epoxyalkane:CoM transferase/CoM & $50 \mathrm{mM}$ Tris- $\mathrm{HCl}, \mathrm{pH} 8.0$ & 30 & -31.4 & -102.9 & -71.5 & 46 \\
\hline Epoxyalkane:CoM transferase/ethanethiol & $50 \mathrm{mM}$ Tris- $\mathrm{HCl}, \mathrm{pH} 8.0$ & 30 & -20.1 & -2.5 & -17.6 & 46 \\
\hline Epoxyalkane:CoM transferase/ethanesulfonate & $50 \mathrm{mM}$ Tris- $\mathrm{HCl}, \mathrm{pH} 8.0$ & 30 & -13.8 & -15.1 & -1.3 & 46 \\
\hline Epoxyalkane:CoM transferase/propanethiol & $50 \mathrm{mM}$ Tris- $\mathrm{HCl}, \mathrm{pH} 8.0$ & 30 & -23.4 & -0.8 & 22.6 & 46 \\
\hline Biotin holoenzyme synthetase/biotin & $10 \mathrm{mM}$ Tris- $\mathrm{HCl}, 200 \mathrm{mM} \mathrm{KCl}, 2.5 \mathrm{mM} \mathrm{MgCl}_{2}, \mathrm{pH} 7.5$ & 20 & -41.4 & -39.3 & 2.1 & 47 \\
\hline Biotin holoenzyme synthetase/bio-5'-AMP & $10 \mathrm{mM}$ Tris- $\mathrm{HCl}, 200 \mathrm{mM} \mathrm{KCl}, 2.5 \mathrm{mM} \mathrm{MgCl}_{2}$, pH 7.5 & 20 & -58.6 & -24.3 & 33.9 & 47 \\
\hline Adenosine deaminase/inosine & $50 \mathrm{mM}$ sodium phosphate, $\mathrm{pH} 7.5$ & 27 & -22.1 & -32.0 & -9.9 & 48 \\
\hline YajQ/ATP & 50 mM Tris-HCl, $\mathrm{pH} 7.4$ & 25 & -22.8 & 1.5 & 24.4 & 49 \\
\hline DNA gyrase/clorobiocin & 20 mM Tris, 1 mM EDTA, pH 7.5 & 25 & -51.0 & -39.6 & 11.4 & 50 \\
\hline DNA gyrase/RU 64135 & 20 mM Tris, 1 mM EDTA, pH 7.5 & 25 & -40.3 & -18.9 & 21.4 & 50 \\
\hline DNA gyrase/RU 64136 & 20 mM Tris, 1 mM EDTA, pH 7.5 & 25 & -35.1 & -18.0 & 17.1 & 50 \\
\hline DNA gyrase/novobiocin & 20 mM Tris, 1 mM EDTA, pH 7.5 & 25 & -42.7 & -51.8 & -9.1 & 50 \\
\hline HIV-1 protease/TMC-126 & $10 \mathrm{mM}$ sodium acetate, $2 \% \mathrm{DMSO}, \mathrm{pH} 5$ & 25 & -65.3 & -50.2 & 15.1 & 51 \\
\hline HIV-1 protease/amprenavir & $10 \mathrm{mM}$ sodium acetate, $2 \% \mathrm{DMSO}, \mathrm{pH} 5$ & 25 & -55.2 & -28.9 & 26.4 & 51 \\
\hline Peanut agglutinin/ Galactose & $20 \mathrm{mM}$ citrate buffer, $\mathrm{pH} 7.4$ & 25 & -17.0 & -23.0 & -6.0 & 52 \\
\hline Peanut agglutinin/ GalEMA & $20 \mathrm{mM}$ citrate buffer, $\mathrm{pH} 7.4$ & 25 & -21.4 & -39.4 & -18 & 52 \\
\hline Peanut agglutinin/ pGalEMA-A & $20 \mathrm{mM}$ citrate buffer, $\mathrm{pH} 7.4$ & 25 & -26.6 & -5.8 & 20.8 & 52 \\
\hline Peanut agglutinin/ $\mathrm{pGalEMA-B}$ & $20 \mathrm{mM}$ citrate buffer, $\mathrm{pH} 7.4$ & 25 & -22.7 & -19.8 & 2.8 & 52 \\
\hline Peanut agglutinin/ Galactose $c$ & $20 \mathrm{mM}$ citrate buffer, $150 \mathrm{mM} \mathrm{NaCl}, \mathrm{pH} 7.4$ & 25 & -16.5 & -23.9 & -7.4 & 52 \\
\hline Peanut agglutinin/ pGalEMA-A & $20 \mathrm{mM}$ citrate buffer, $150 \mathrm{mM} \mathrm{NaCl}, \mathrm{pH} 7.4$ & 25 & -21.7 & -10.8 & 10.9 & 52 \\
\hline Peanut agglutinin/ $\mathrm{pGalEMA-B}$ & $20 \mathrm{mM}$ citrate buffer, $150 \mathrm{mM} \mathrm{NaCl}, \mathrm{pH} 7.4$ & 25 & -21.2 & -8.3 & 12.9 & 52 \\
\hline Peanut agglutinin/ $\mathrm{pGalEMA-A}$ & $20 \mathrm{mM}$ citrate buffer, $150 \mathrm{mM} \mathrm{NaCl}, \mathrm{pH}$ 7.4, heats of dilution subtracted & 25 & -20.6 & -6.4 & 14.2 & 52 \\
\hline Peanut agglutinin/ $\mathrm{pGalEMA-A}$ & $\begin{array}{l}50 \mathrm{mM} \text { Tris- } \mathrm{HCl} \text { buffer, } 500 \mathrm{mM} \mathrm{MgCl}_{2}, 1 \mathrm{mM} \mathrm{MnCl} 2,1 \mathrm{mM} \mathrm{CaCl}_{2}, \mathrm{pH} \\
6.9\end{array}$ & 25 & -17.9 & -15.8 & 2.1 & 52 \\
\hline Peanut agglutinin/ pGalEMA-A & $\begin{array}{l}50 \mathrm{mM} \text { Tris- } \mathrm{HCl} \text { buffer, } 500 \mathrm{mM} \mathrm{MgCl} \\
6.9 \text {, heats of dilution subtracted }\end{array}$ & 25 & -18.6 & -42.6 & -24.0 & 52 \\
\hline Wild-Type MUP/ IBMP & PBS, pH 7.4 & 35 & -38.5 & -47.9 & -9.4 & 53 \\
\hline Y120F MUP/ IBMP & PBS, pH 7.4 & 15 & -34.9 & -25.8 & 9.1 & 53 \\
\hline Y120F MUP/ IBMP & PBS, pH 7.4 & 25 & -35.3 & -31.4 & 3.9 & 53 \\
\hline Y120F MUP/ IBMP & PBS, pH 7.4 & 35 & -33.6 & -35.9 & -2.3 & 53 \\
\hline Rho/ Bicyclomycin & $40 \mathrm{mM}$ Tris $\mathrm{HCl} 400 \mathrm{mM} \mathrm{KCl}, 0.1 \mathrm{mM}$ EDTA, and $0.1 \mathrm{mM}$ DTT, pH 7.9 & 26 & -25.1 & -3.3 & 21.8 & 54 \\
\hline Rho/ Bicyclomycin analogue & $40 \mathrm{mM}$ Tris $\mathrm{HCl} 400 \mathrm{mM} \mathrm{KCl}, 0.1 \mathrm{mM}$ EDTA, and $0.1 \mathrm{mM}$ DTT, pH 7.9 & 26 & -32.2 & -11.5 & 20.7 & 54 \\
\hline BirA/ Biotin & $10 \mathrm{mM}$ Tris- $\mathrm{HCl}, 200 \mathrm{mM} \mathrm{KCl}, 2.5 \mathrm{mM} \mathrm{MgCl} 2, \mathrm{pH} 7.50$ & 20 & -41.4 & -80.3 & -38.9 & 55 \\
\hline BirA/ Btn-SA & $10 \mathrm{mM}$ Tris- $\mathrm{HCl}, 200 \mathrm{mM} \mathrm{KCl}, 2.5 \mathrm{mM} \mathrm{MgCl} 2, \mathrm{pH} 7.50$ & 20 & -40.6 & -83.3 & -42.7 & 55 \\
\hline BirA/ BtnOH-AMP & $10 \mathrm{mM}$ Tris- $\mathrm{HCl}, 200 \mathrm{mM} \mathrm{KCl,} 2.5 \mathrm{mM} \mathrm{MgCl} 2, \mathrm{pH} 7.50$ & 20 & -49.5 & -41.4 & 7.9 & 55 \\
\hline BirA/ Bio-5' -AMP & $10 \mathrm{mM}$ Tris- $\mathrm{HCl}, 200 \mathrm{mM} \mathrm{KCl}, 2.5 \mathrm{mM} \mathrm{MgCl} 2, \mathrm{pH} 7.50$ & 20 & -58.2 & -51.5 & 6.7 & 55 \\
\hline ConA/methyl $\alpha$-D-mannopyranoside & $0.1 \mathrm{M}$ sodium acetate, $0.1 \mathrm{M} \mathrm{NaCl}, 5 \mathrm{mM}$ each $\mathrm{CaCl}_{2}$ and $\mathrm{MnCl}_{2}, \mathrm{pH} 5.2$ & 27 & -23.4 & -35.1 & -11.7 & 56 \\
\hline ConA/ Bivalant sugar derivative 1 & $0.1 \mathrm{M}$ sodium acetate, $0.1 \mathrm{M} \mathrm{NaCl}, 5 \mathrm{mM}$ each $\mathrm{CaCl}_{2}$ and $\mathrm{MnCl}_{2}, \mathrm{pH} 5.2$ & 27 & -25.1 & -46.9 & -21.8 & 56 \\
\hline ConA/ Bivalant sugar derivative 2 & $0.1 \mathrm{M}$ sodium acetate, $0.1 \mathrm{M} \mathrm{NaCl}, 5 \mathrm{mM}$ each $\mathrm{CaCl}_{2}$ and $\mathrm{MnCl}_{2}, \mathrm{pH} 5.2$ & 27 & -25.1 & -59.0 & -33.9 & 56 \\
\hline
\end{tabular}


ConA/ Bivalant sugar derivative 3 ConA/ Bivalant sugar derivative 4 ConA/ Bivalant sugar derivative 5 ConA/ Bivalant sugar derivative 6 ConA/ Bivalant sugar derivative 7 ConA/ Bivalant sugar derivative 8 ConA/ Bivalant sugar derivative 9 ConA/ Bivalant sugar derivative 10 ConA/ Bivalant sugar derivative 11 ConA/ Bivalant sugar derivative 12 ConA/ Bivalant sugar derivative 13 DGL/methyl $\alpha$-D-mannopyranoside DGL/ Bivalant sugar derivative 1 DGL/ Bivalant sugar derivative 2 DGL/ Bivalant sugar derivative 3 DGL/ Bivalant sugar derivative 4 DGL/ Bivalant sugar derivative 5 DGL/ Bivalant sugar derivative 6 DGL/ Bivalant sugar derivative 7 DGL/ Bivalant sugar derivative 8 DGL/ Bivalant sugar derivative 9 DGL/ Bivalant sugar derivative 10 DGL/ Bivalant sugar derivative 11 DGL/ Bivalant sugar derivative 12 DGL/ Bivalant sugar derivative 13 BSA/ Naproxen

TtgV/ 1-Naphthol

TtgV-DNA complex/ 1-Naphthol TtgV/ 2,3-Dihydroxynaphthalene

TtgV/ 4-Nitrotoluene

TtgV/ Benzonitrile

$\mathrm{Ttg} \mathrm{V} /$ Indole

$\mathrm{TtgV} /$ Tolune

$\mathrm{TtgV} / 1$-Hexanol

Porcine odorant binding protein/ Halothane Porcine odorant binding protein/Isoflurane

Tetracycline Repressor/ Tetracycline

Tetracycline Repressor/ Tetracycline with $\mathrm{Mg}^{2+}$ $\beta$-trypsin/ Benzamidine/ Glycine- 0.00 $\beta$-trypsin/ Benzamidine/ Glycine- 0.25 $\beta$-trypsin/ Benzamidine/ Glycine- 0.50 $\beta$-trypsin/ Benzamidine/ Glycine- 1.00 $\beta$-trypsin/ Benzamidine/ Glucose-0.00 $\beta$-trypsin/ Benzamidine/ Glucose-0.38 $\beta$-trypsin/ Benzamidine/ Glucose- 0.75
$0.1 \mathrm{M}$ sodium acetate, $0.1 \mathrm{M} \mathrm{NaCl}, 5 \mathrm{mM}$ each $\mathrm{CaCl}_{2}$ and $\mathrm{MnCl}_{2}$, $\mathrm{pH} 5.2$ $0.1 \mathrm{M}$ sodium acetate, $0.1 \mathrm{M} \mathrm{NaCl}, 5 \mathrm{mM}$ each $\mathrm{CaCl}_{2}$ and $\mathrm{MnCl}_{2}$, pH 5.2 $0.1 \mathrm{M}$ sodium acetate, $0.1 \mathrm{M} \mathrm{NaCl}, 5 \mathrm{mM}$ each $\mathrm{CaCl}_{2}$ and $\mathrm{MnCl}_{2}$, pH 5.2 $0.1 \mathrm{M}$ sodium acetate, $0.1 \mathrm{M} \mathrm{NaCl}, 5 \mathrm{mM}$ each $\mathrm{CaCl}_{2}$ and $\mathrm{MnCl}_{2}$, pH 5.2 $0.1 \mathrm{M}$ sodium acetate, $0.1 \mathrm{M} \mathrm{NaCl}, 5 \mathrm{mM}$ each $\mathrm{CaCl}_{2}$ and $\mathrm{MnCl}_{2}, \mathrm{pH} 5.2$ $0.1 \mathrm{M}$ sodium acetate, $0.1 \mathrm{M} \mathrm{NaCl}, 5 \mathrm{mM}$ each $\mathrm{CaCl}_{2}$ and $\mathrm{MnCl}_{2}$, pH 5.2 $0.1 \mathrm{M}$ sodium acetate, $0.1 \mathrm{M} \mathrm{NaCl}, 5 \mathrm{mM}$ each $\mathrm{CaCl}_{2}$ and $\mathrm{MnCl}_{2}, \mathrm{pH} 5.2$ $0.1 \mathrm{M}$ sodium acetate, $0.1 \mathrm{M} \mathrm{NaCl}, 5 \mathrm{mM}$ each $\mathrm{CaCl}_{2}$ and $\mathrm{MnCl}_{2}$, $\mathrm{pH} 5.2$ $0.1 \mathrm{M}$ sodium acetate, $0.1 \mathrm{M} \mathrm{NaCl}, 5 \mathrm{mM}$ each $\mathrm{CaCl}_{2}$ and $\mathrm{MnCl}_{2}, \mathrm{pH} 5.2$ $0.1 \mathrm{M}$ sodium acetate, $0.1 \mathrm{M} \mathrm{NaCl}, 5 \mathrm{mM}$ each $\mathrm{CaCl}_{2}$ and $\mathrm{MnCl}_{2}, \mathrm{pH} 5.2$ $0.1 \mathrm{M}$ sodium acetate, $0.1 \mathrm{M} \mathrm{NaCl}, 5 \mathrm{mM}$ each $\mathrm{CaCl}_{2}$ and $\mathrm{MnCl}_{2}, \mathrm{pH} 5.2$ $0.1 \mathrm{M}$ sodium acetate, $0.1 \mathrm{M} \mathrm{NaCl}, 5 \mathrm{mM}$ each $\mathrm{CaCl}_{2}$ and $\mathrm{MnCl}_{2}, \mathrm{pH} 5.2$ $0.1 \mathrm{M}$ sodium acetate, $0.1 \mathrm{M} \mathrm{NaCl}, 5 \mathrm{mM}$ each $\mathrm{CaCl}_{2}$ and $\mathrm{MnCl}_{2}$, pH 5.2 $0.1 \mathrm{M}$ sodium acetate, $0.1 \mathrm{M} \mathrm{NaCl}, 5 \mathrm{mM}$ each $\mathrm{CaCl}_{2}$ and $\mathrm{MnCl}_{2}$, pH 5.2 $0.1 \mathrm{M}$ sodium acetate, $0.1 \mathrm{M} \mathrm{NaCl}, 5 \mathrm{mM}$ each $\mathrm{CaCl}_{2}$ and $\mathrm{MnCl}_{2}, \mathrm{pH} 5.2$ $0.1 \mathrm{M}$ sodium acetate, $0.1 \mathrm{M} \mathrm{NaCl}, 5 \mathrm{mM}$ each $\mathrm{CaCl}_{2}$ and $\mathrm{MnCl}_{2}, \mathrm{pH} 5.2$ $0.1 \mathrm{M}$ sodium acetate, $0.1 \mathrm{M} \mathrm{NaCl}, 5 \mathrm{mM}$ each $\mathrm{CaCl}_{2}$ and $\mathrm{MnCl}_{2}$, pH 5.2 $0.1 \mathrm{M}$ sodium acetate, $0.1 \mathrm{M} \mathrm{NaCl}, 5 \mathrm{mM}$ each $\mathrm{CaCl}_{2}$ and $\mathrm{MnCl}_{2}, \mathrm{pH} 5.2$ $0.1 \mathrm{M}$ sodium acetate, $0.1 \mathrm{M} \mathrm{NaCl}, 5 \mathrm{mM}$ each $\mathrm{CaCl}_{2}$ and $\mathrm{MnCl}_{2}, \mathrm{pH} 5.2$ $0.1 \mathrm{M}$ sodium acetate, $0.1 \mathrm{M} \mathrm{NaCl}, 5 \mathrm{mM}$ each $\mathrm{CaCl}_{2}$ and $\mathrm{MnCl}_{2}, \mathrm{pH} 5.2$ $0.1 \mathrm{M}$ sodium acetate, $0.1 \mathrm{M} \mathrm{NaCl}, 5 \mathrm{mM}$ each $\mathrm{CaCl}_{2}$ and $\mathrm{MnCl}_{2}, \mathrm{pH} 5.2$ $0.1 \mathrm{M}$ sodium acetate, $0.1 \mathrm{M} \mathrm{NaCl}, 5 \mathrm{mM}$ each $\mathrm{CaCl}_{2}$ and $\mathrm{MnCl}_{2}, \mathrm{pH} 5.2$ $0.1 \mathrm{M}$ sodium acetate, $0.1 \mathrm{M} \mathrm{NaCl}, 5 \mathrm{mM}$ each $\mathrm{CaCl}_{2}$ and $\mathrm{MnCl}_{2}, \mathrm{pH} 5.2$ $0.1 \mathrm{M}$ sodium acetate, $0.1 \mathrm{M} \mathrm{NaCl}, 5 \mathrm{mM}$ each $\mathrm{CaCl}_{2}$ and $\mathrm{MnCl}_{2}$, pH 5.2 $0.1 \mathrm{M}$ sodium acetate, $0.1 \mathrm{M} \mathrm{NaCl}, 5 \mathrm{mM}$ each $\mathrm{CaCl}_{2}$ and $\mathrm{MnCl}_{2}$, pH 5.2 $50 \mathrm{mM}$ sodium phosphate buffer, $\mathrm{pH} 7.4$

$25 \mathrm{mM}$ Tris-HOAc, $8 \mathrm{mM} \mathrm{Mg}(\mathrm{OAc})_{2}, 1 \mathrm{mM} \mathrm{KCl}, 1 \mathrm{mM}$ dithiothreitol, $\mathrm{pH} 8.0$ $25 \mathrm{mM}$ Tris-HOAc, $8 \mathrm{mM} \mathrm{Mg}(\mathrm{OAc})_{2}, 1 \mathrm{mM} \mathrm{KCl}, 1 \mathrm{mM}$ dithiothreitol,pH 8.0 $25 \mathrm{mM}$ Tris-HOAc, $8 \mathrm{mM} \mathrm{Mg}(\mathrm{OAc})_{2}, 1 \mathrm{mM} \mathrm{KCl}, 1 \mathrm{mM}$ dithiothreitol, $\mathrm{pH} 8.0$ $25 \mathrm{mM}$ Tris-HOAc, $8 \mathrm{mM} \mathrm{Mg}(\mathrm{OAc})_{2}, 1 \mathrm{mM} \mathrm{KCl}, 1 \mathrm{mM}$ dithiothreitol, $\mathrm{pH} 8.0$ $25 \mathrm{mM}$ Tris-HOAc, $8 \mathrm{mM} \mathrm{Mg}(\mathrm{OAc})_{2}, 1 \mathrm{mM} \mathrm{KCl}, 1 \mathrm{mM}$ dithiothreitol, $\mathrm{pH} 8.0$ $25 \mathrm{mM}$ Tris-HOAc, $8 \mathrm{mM} \mathrm{Mg}(\mathrm{OAc})_{2}, 1 \mathrm{mM} \mathrm{KCl}, 1 \mathrm{mM}$ dithiothreitol,pH 8.0 $25 \mathrm{mM}$ Tris-HOAc, $8 \mathrm{mM} \mathrm{Mg}(\mathrm{OAc})_{2}, 1 \mathrm{mM} \mathrm{KCl}, 1 \mathrm{mM}$ dithiothreitol, $\mathrm{pH} 8.0$

$25 \mathrm{mM}$ Tris-HOAc, $8 \mathrm{mM} \mathrm{Mg}(\mathrm{OAc})_{2}, 1 \mathrm{mM} \mathrm{KCl}, 1 \mathrm{mM}$ dithiothreitol, $\mathrm{pH} 8.0$

$130 \mathrm{~mm} \mathrm{NaCl}, 20 \mathrm{~mm}$ sodium phosphate, $\mathrm{pH} 7.0$

$130 \mathrm{~mm} \mathrm{NaCl}, 20 \mathrm{~mm}$ sodium phosphate, $\mathrm{pH} 7.0$

$10 \mathrm{mM}$ Tris, $150 \mathrm{mM} \mathrm{NaCl}$, and $2 \mathrm{mM}$ DTT with $1 \mathrm{mM}$ EDTA, $\mathrm{pH} 8.0$

$10 \mathrm{mM}$ Tris, $150 \mathrm{mM} \mathrm{NaCl}$, and $2 \mathrm{mM}$ DTT with $10 \mathrm{mM} \mathrm{MgCl}_{2}, \mathrm{pH} 8.0$ $50 \mathrm{mM}$ Tris buffer, with $25 \mathrm{mM} \mathrm{CaCl}_{2}$, at $\mathrm{pH} 8.0$

$50 \mathrm{mM}$ Tris buffer, with $25 \mathrm{mM} \mathrm{CaCl}_{2}$, at $\mathrm{pH} 8.0$

$50 \mathrm{mM}$ Tris buffer, with $25 \mathrm{mM} \mathrm{CaCl}_{2}$, at $\mathrm{pH} 8.0$

$50 \mathrm{mM}$ Tris buffer, with $25 \mathrm{mM} \mathrm{CaCl}_{2}$, at $\mathrm{pH} 8.0$

$50 \mathrm{mM}$ Tris buffer, with $25 \mathrm{mM} \mathrm{CaCl}_{2}$, at $\mathrm{pH} 8.0$

$50 \mathrm{mM}$ Tris buffer, with $25 \mathrm{mM} \mathrm{CaCl}_{2}$, at $\mathrm{pH} 8.0$

$50 \mathrm{mM}$ Tris buffer, with $25 \mathrm{mM} \mathrm{CaCl}_{2}$, at $\mathrm{pH} 8.0$

\begin{tabular}{llll}
-24.7 & -53.1 & -28.0 & 56 \\
-25.1 & -47.7 & -22.6 & 56 \\
-26.4 & -43.1 & -16.7 & 56 \\
-26.8 & -56.1 & -29.3 & 56 \\
-26.8 & -61.5 & -34.7 & 56 \\
-27.2 & -63.6 & -36.4 & 56 \\
-26.8 & -71.1 & -44.4 & 56 \\
-27.2 & -69.5 & -42.3 & 56 \\
-27.6 & -64.4 & -36.8 & 56 \\
-27.6 & -59.8 & -32.2 & 56 \\
-27.2 & -66.5 & -39.3 & 56 \\
-20.5 & -34.3 & -13.8 & 56 \\
-24.3 & -42.3 & -18.0 & 56 \\
-24.7 & -45.2 & -20.5 & 56 \\
-24.7 & -46.9 & -22.2 & 56 \\
-23.8 & -46.0 & -22.2 & 56 \\
-26.4 & -43.5 & -17.2 & 56 \\
-27.2 & -48.5 & -21.3 & 56 \\
-28.0 & -54.0 & -25.9 & 56 \\
-28.9 & -61.9 & -33.0 & 56 \\
-23.8 & -59.8 & -36.0 & 56 \\
-25.1 & -61.9 & -36.8 & 56 \\
-26.8 & -65.3 & -38.5 & 56 \\
-25.9 & -50.2 & -24.3 & 56 \\
-25.1 & -64.0 & -38.9 & 56 \\
-44.8 & -50.7 & -5.8 & 57 \\
-31.4 & -36.0 & -4.6 & 58 \\
-30.5 & -21.8 & 8.8 & 58 \\
-32.2 & -3.4 & 28.9 & 58 \\
-26.8 & -62.3 & -35.6 & 58 \\
-24.3 & -52.3 & -28.0 & 58 \\
-23.8 & -54.4 & -30.5 & 58 \\
-22.6 & -26.4 & -3.8 & 58 \\
-17.2 & -62.3 & -45.2 & 58 \\
-23.0 & -5.9 & 17.2 & 59 \\
-22.6 & -10.0 & 12.6 & 59 \\
-27.7 & -32.9 & -5.3 & 60 \\
-39.7 & -51.5 & -11.6 & 60 \\
-26.8 & -15.2 & 11.6 & 61 \\
-26.8 & -12.5 & 14.3 & 61 \\
-26.1 & -7.1 & 19.1 & 61 \\
-25.7 & -6.5 & 19.2 & 61 \\
-26.8 & -15.2 & 11.6 & 61 \\
-26.7 & -15.2 & 11.6 & 61 \\
-26.2 & -11.4 & 14.7 & 61 \\
\hline & & &
\end{tabular}


$\beta$-trypsin/ Berenil/ Glycine- 0.00

$\beta$-trypsin/ Berenil/ Glycine-0.38

$\beta$-trypsin/ Berenil/ Glycine- 0.75

$\beta$-trypsin/ Berenil/ Glycine-1.00

$\beta$-trypsin/ Berenil/ Glucose-0.00

$\beta$-trypsin/ Berenil/ Glucose-0.25

$\beta$-trypsin/ Berenil/ Glucose- 0.50

-trypsin/ Berenil/ Glucose-1.00

MUP-I-wild type/SBT

MUP-I-wild type/HMH

MUP-I/ IPMP

MUP-I/IBMP

Integrin I-domain/ inhibitor 1

GH1 $\beta$-glucosidase/Aza sugar glycosidase inhibitor 6

GH1 $\beta$-glucosidase/Aza sugar glycosidase inhibitor 1

GH1 $\beta$-glucosidase/Aza sugar glycosidase inhibitor 5

Cellobiohydrolase I / (S)-alprenolol

Cellobiohydrolase I / (S)-alprenolol

Cellobiohydrolase I / (S)-alprenolol

Cellobiohydrolase I / $(R)$-alprenolol

HIV protease $1 / \mathrm{APV}$

HIV protease 1/ TMC114

hGSTA1-1 High-affinity site/ BSP

hGSTA1-1_Low-affinity site/ BSP

HAS/ Halothane (variable n)

HAS/ Halothane (fixed $n$ )

HAS/ Propofol

APH(3')-IIIa (Binary Complex)/ kanamycine A

APH(3')-IIIa (Binary Complex)/ kanamycine A

APH(3')-IIIa (Binary Complex)/ kanamycine B

APH(3')-IIIa (Binary Complex)/ kanamycine B

APH(3')-IIIa (Binary Complex)/ tobramycin

APH(3')-IIIa (Binary Complex)/ tobramycin

APH(3')-IIIa (Binary Complex)/ amikacin

APH(3')-IIIa (Binary Complex)/ amikacin

APH(3')-IIIa (Binary Complex)/ ribostamycin

APH(3')-IIIa (Binary Complex)/ ribostamycin

APH(3')-IIIa (Binary Complex)/ meomycine B

APH(3')-IIIa (Binary Complex)/ meomycine B

APH(3')-IIIa (Binary Complex)/ paromomycine

APH(3')-IIIa (Binary Complex)/ paromomycine I

APH(3')-IIIa (Binary Complex)/ lividomycine A
$50 \mathrm{mM}$ Tris buffer, with $25 \mathrm{mM} \mathrm{CaCl}_{2}$, at $\mathrm{pH} 8.0$

$50 \mathrm{mM}$ Tris buffer, with $25 \mathrm{mM} \mathrm{CaCl}_{2}$, at $\mathrm{pH} 8.0$

$50 \mathrm{mM}$ Tris buffer, with $25 \mathrm{mM} \mathrm{CaCl}_{2}$, at $\mathrm{pH} 8.0$

$50 \mathrm{mM}$ Tris buffer, with $25 \mathrm{mM} \mathrm{CaCl}_{2}$, at $\mathrm{pH} 8.0$

$50 \mathrm{mM}$ Tris buffer, with $25 \mathrm{mM} \mathrm{CaCl}_{2}$, at $\mathrm{pH} 8.0$

$50 \mathrm{mM}$ Tris buffer, with $25 \mathrm{mM} \mathrm{CaCl}_{2}$, at pH 8.0

$50 \mathrm{mM}$ Tris buffer, with $25 \mathrm{mM} \mathrm{CaCl}_{2}$, at $\mathrm{pH} 8.0$

$50 \mathrm{mM}$ Tris buffer, with $25 \mathrm{mM} \mathrm{CaCl}_{2}$, at $\mathrm{pH} 8.0$

$10 \mathrm{mM}$ phosphate, $0.02 \% \mathrm{NaN}_{3}, \mathrm{pH} 6.3$

$10 \mathrm{mM}$ phosphate, $0.02 \% \mathrm{NaN}_{3}$, $\mathrm{pH} 6.3$

PBS, pH 7.4

PBS, $\mathrm{pH} 7.4$

$20 \mathrm{mM}$ Tris base, $150 \mathrm{mM} \mathrm{NaCl}$, and $1 \mathrm{mM} \mathrm{MgCl} 2,2 \% \mathrm{DMSO}, \mathrm{pH} 7.5$

$100 \mathrm{mM}$ sodium citrate buffer, $\mathrm{pH} 5.8$

$100 \mathrm{mM}$ sodium citrate buffer, $\mathrm{pH} 5.8$

$100 \mathrm{mM}$ sodium citrate buffer, $\mathrm{pH} 5.8$

sodium acetate buffer, $\mathrm{pH} 5.5$

sodium acetate buffer, $\mathrm{pH} 5.8$

sodium acetate buffer, $\mathrm{pH} 6.8$

sodium acetate buffer, $\mathrm{pH} 6.8$

$10 \mathrm{mM} \mathrm{Na}$ acetate, $2 \% \mathrm{DMSO}, 2 \mathrm{mM}$ Tris(2-carboxyethyl)phosphine, $\mathrm{pH} 5$

$10 \mathrm{mM} \mathrm{Na}$ acetate, $2 \% \mathrm{DMSO}, 2 \mathrm{mM}$ Tris(2-carboxyethyl)phosphine, $\mathrm{pH} 5$

sodium phosphate, $150 \mathrm{mM} \mathrm{NaCl}, \mathrm{pH} 6.5$

sodium phosphate, $150 \mathrm{mM} \mathrm{NaCl}$, pH 6.5

$20 \mathrm{mM}$ Sodium phosphate buffer, $130 \mathrm{mM} \mathrm{NaCl}, \mathrm{pH} 7.0$

$20 \mathrm{mM}$ Sodium phosphate buffer, $130 \mathrm{mM} \mathrm{NaCl}, \mathrm{pH} 7.0$

$20 \mathrm{mM}$ Sodium phosphate buffer, $130 \mathrm{mM} \mathrm{NaCl}, \mathrm{pH} 7.0$

$50 \mathrm{mM}$ Tris buffer, $100 \mathrm{mM} \mathrm{KCl}, \mathrm{pH} 7.5$

$50 \mathrm{mM}$ Bicine buffer, $100 \mathrm{mM} \mathrm{KCl}, \mathrm{pH} 7.5$

$50 \mathrm{mM}$ Tris buffer, $100 \mathrm{mM} \mathrm{KCl}, \mathrm{pH} 7.5$

$50 \mathrm{mM}$ Bicine buffer, $100 \mathrm{mM} \mathrm{KCl}$, pH 7.5

$50 \mathrm{mM}$ Tris buffer, $100 \mathrm{mM} \mathrm{KCl}, \mathrm{pH} 7.5$

$50 \mathrm{mM}$ Bicine buffer, $100 \mathrm{mM} \mathrm{KCl,} \mathrm{pH} \mathrm{7.5}$

$50 \mathrm{mM}$ Tris buffer, $100 \mathrm{mM} \mathrm{KCl}, \mathrm{pH} 7.5$

$50 \mathrm{mM}$ Bicine buffer, $100 \mathrm{mM} \mathrm{KCl}, \mathrm{pH} 7.5$

$50 \mathrm{mM}$ Tris buffer, $100 \mathrm{mM} \mathrm{KCl}, \mathrm{pH} 7.5$

$50 \mathrm{mM}$ Bicine buffer, $100 \mathrm{mM} \mathrm{KCl}, \mathrm{pH} 7.5$

$50 \mathrm{mM}$ Tris buffer, $100 \mathrm{mM} \mathrm{KCl}, \mathrm{pH} 7.5$

$50 \mathrm{mM}$ Bicine buffer, $100 \mathrm{mM} \mathrm{KCl}, \mathrm{pH} 7.5$

$50 \mathrm{mM}$ Tris buffer, $100 \mathrm{mM} \mathrm{KCl}, \mathrm{pH} 7.5$

$50 \mathrm{mM}$ Bicine buffer, $100 \mathrm{mM} \mathrm{KCl}, \mathrm{pH} 7.5$

$50 \mathrm{mM}$ Tris buffer, $100 \mathrm{mM} \mathrm{KCl}, \mathrm{pH} 7.5$ $\begin{array}{llll}-33.0 & -17.2 & 15.8 & 61\end{array}$

$\begin{array}{llll}-32.8 & -12.3 & 20.5 & 61\end{array}$

$\begin{array}{llll}-32.2 & -12.3 & 19.9 & 6\end{array}$

22.2

$\begin{array}{llll}-33.0 & -17.2 & 15.8 & 61\end{array}$

$\begin{array}{llll}-32.2 & -18.3 & 13.9 & 61\end{array}$

$\begin{array}{llll}-32.0 & -14.1 & 17.9 & 61\end{array}$

$\begin{array}{lll}-32.2 & -10.5 & 21.7\end{array}$

$\begin{array}{llll}-34.7 & -45.6 & -10.9 & 62\end{array}$

$\begin{array}{llll}-25.1 & -54.4 & -29.3 & 62\end{array}$

$\begin{array}{llll}-33.9 & -44.5 & -10.6 & 63\end{array}$

$\begin{array}{llll}-38.5 & -47.9 & -9.4 & 63\end{array}$

$\begin{array}{llll}-44.9 & -32.2 & 12.7 & 64\end{array}$

$\begin{array}{llll}-41.2 & -28.5 & 12.9 & 65\end{array}$

$\begin{array}{llll}-36.3 & -46.7 & -10.5 & 65\end{array}$

$\begin{array}{lll}-29.0 & -33.2-3.9\end{array}$

$\begin{array}{llll}-24.1 & 17.6 & 42.4 & 66\end{array}$

$\begin{array}{llll}-25.2 & 20.5 & 44.9 & 66\end{array}$

$\begin{array}{llll}-26.9 & 38.9 & 66.1 & 66\end{array}$

$\begin{array}{llll}-21.3 & 8.4 & 29.9 & 66\end{array}$

$\begin{array}{llll}-52.7 & -30.5 & 22.2 & 67\end{array}$

$\begin{array}{llll}-63.6 & -50.6 & 13.0 & 67\end{array}$

$\begin{array}{llll}-38.9 & -23.5 & 15.5 & 68\end{array}$

$\begin{array}{llll}-28.3 & -7.2 & 19.7 & 68 \\ -15.6 & -5.5 & 10.2 & 69\end{array}$

$\begin{array}{llll}-15.6 & -5.5 & 10.2 & 69\end{array}$

$\begin{array}{llll}-15.6 & -6.0 & 9.6 & 69\end{array}$

$\begin{array}{llll}-23.5 & -21.8 & 1.7 & 69\end{array}$

$\begin{array}{llll}-31.0 & -138.1 & -107.1 & 70\end{array}$

$\begin{array}{llll}-31.4 & -160.2 & -128.9 & 70\end{array}$

$\begin{array}{llll}-38.5 & -93.7 & -55.2 & 70\end{array}$

$\begin{array}{llll}-37.7 & -128.9 & -91.2 & 70\end{array}$

$\begin{array}{llll}-36.4 & -122.2 & -85.8 & 70\end{array}$

$\begin{array}{llll}-36.8 & -155.2 & -118.4 & 70\end{array}$

$\begin{array}{llll}-23.8 & -81.6 & -57.7 & 70\end{array}$

$\begin{array}{llll}-25.9 & -78.7 & -52.7 & 70\end{array}$

$\begin{array}{llll}-33.9 & -125.9 & -92.0 & 70\end{array}$

$\begin{array}{lll}-117.6 & -83.7 & 70\end{array}$

$\begin{array}{llll}-38.9 & -139.7 & -100.8 & 70\end{array}$

$\begin{array}{llll}-38.9 & -181.2 & -142.3 & 70\end{array}$

$\begin{array}{llll}-37.7 & -127.2 & -89.5 & 70\end{array}$

$\begin{array}{llll}-38.9 & -152.3 & -113.4 & 70\end{array}$

$\begin{array}{llll}-38.9 & -152.3 & -113.4 & 70 \\ -36.0 & -140.6 & -104.6 & 70\end{array}$


APH(3')-IIIa (Binary Complex)/ lividomycine A APH(3')-IIIa (Ternery Complex)/ kanamycine A APH(3')-IIIa (Ternery Complex)/ kanamycine A APH(3')-IIIa (Ternery Complex)/ kanamycine B APH(3')-IIIa (Ternery Complex)/ kanamycine B APH(3')-IIIa (Ternery Complex)/ tobramycin APH(3')-IIIa (Ternery Complex)/ tobramycin APH(3')-IIIa (Ternery Complex)/ amikacin APH(3')-IIIa (Ternery Complex)/ amikacin APH(3')-IIIa (Ternery Complex)/ ribostamycin APH(3')-IIIa (Ternery Complex)/ ribostamycin APH(3')-IIIa (Ternery Complex)/ meomycine B APH(3')-IIIa (Ternery Complex)/ meomycine B APH(3')-IIIa (Ternery Complex)/ paromomycine I APH(3')-IIIa (Ternery Complex)/ paromomycine APH(3')-IIIa (Ternery Complex)/ lividomycine A APH(3')-IIIa (Ternery Complex)/ lividomycine A APH(3')-IIIa (Ternery Complex)/ kanamycine A APH(3')-IIIa (Ternery Complex)/ kanamycine A APH(3')-IIIa (Ternery Complex)/ kanamycine B APH(3')-IIIa (Ternery Complex)/ kanamycine B APH(3')-IIIa (Ternery Complex)/ tobramycin APH(3')-IIIa (Ternery Complex)/ tobramycin APH(3')-IIIa (Ternery Complex)/ meomycine B APH(3')-IIIa (Ternery Complex)/ meomycine B APH(3')-IIIa (Ternery Complex)/ paromomycine APH(3')-IIIa (Ternery Complex)/ paromomycine Tetrameric human $\mathrm{PAH} / \mathrm{BH}_{4}$ Tetrameric human $\mathrm{PAH} / \mathrm{BH}_{4}$

Tetrameric human $\mathrm{PAH} / \mathrm{BH}_{4}$

Tetrameric human $\mathrm{PAH} / \mathrm{BH}_{4}$ Tetrameric human $\mathrm{PAH} / 6 \mathrm{M}-\mathrm{PH}_{4}$ Tetrameric human $\mathrm{PAH} / 6 \mathrm{M}-\mathrm{PH}_{4}$ Tetrameric human $\mathrm{PAH} / 6 \mathrm{M}-\mathrm{PH}_{4}$ Tetrameric human $\mathrm{PAH} / \mathrm{BH}_{4}$ Tetrameric human $\mathrm{PAH} / \mathrm{BH}_{4}$

Tetrameric human $\mathrm{PAH} / \mathrm{BH}_{4}$

Tetrameric human $\mathrm{PAH} / \mathrm{BH}_{4}$

Tetrameric human $\mathrm{PAH} / 6 \mathrm{M}-\mathrm{PH}_{4}$

Tetrameric human $\mathrm{PAH} / \mathrm{BH}_{4}$

Tetrameric human $\mathrm{PAH} / 6 \mathrm{M}-\mathrm{PH}_{4}$

wt FabI/ PD048890

wt FabI/ PD048890
$50 \mathrm{mM}$ Bicine buffer, $100 \mathrm{mM} \mathrm{KCl}, \mathrm{pH} 7.5$ $50 \mathrm{mM}$ Tris buffer, $100 \mathrm{mM} \mathrm{KCl}, \mathrm{pH} 7.5$

$50 \mathrm{mM}$ Bicine buffer, $100 \mathrm{mM} \mathrm{KCl}, \mathrm{pH} 7.5$ $50 \mathrm{mM}$ Tris buffer, $100 \mathrm{mM} \mathrm{KCl}, \mathrm{pH} 7.5$

$50 \mathrm{mM}$ Bicine buffer, $100 \mathrm{mM} \mathrm{KCl}, \mathrm{pH} 7.5$ $50 \mathrm{mM}$ Tris buffer, $100 \mathrm{mM} \mathrm{KCl}, \mathrm{pH} 7.5$ $50 \mathrm{mM}$ Bicine buffer, $100 \mathrm{mM} \mathrm{KCl}, \mathrm{pH} 7.5$ $50 \mathrm{mM}$ Tris buffer, $100 \mathrm{mM} \mathrm{KCl}, \mathrm{pH} 7.5$

$50 \mathrm{mM}$ Bicine buffer, $100 \mathrm{mM} \mathrm{KCl}$, pH 7.5 $50 \mathrm{mM}$ Tris buffer, $100 \mathrm{mM} \mathrm{KCl}$, pH 7.5

$50 \mathrm{mM}$ Bicine buffer, $100 \mathrm{mM} \mathrm{KCl}, \mathrm{pH} 7.5$

$50 \mathrm{mM}$ Tris buffer, $100 \mathrm{mM} \mathrm{KCl}, \mathrm{pH} 7.5$

$50 \mathrm{mM}$ Bicine buffer, $100 \mathrm{mM} \mathrm{KCl}, \mathrm{pH} 7.5$

$50 \mathrm{mM}$ Tris buffer, $100 \mathrm{mM} \mathrm{KCl}$, pH 7.5

$50 \mathrm{mM}$ Bicine buffer, $100 \mathrm{mM} \mathrm{KCl}, \mathrm{pH} 7.5$

$50 \mathrm{mM}$ Tris buffer, $100 \mathrm{mM} \mathrm{KCl}, \mathrm{pH} 7.5$

$50 \mathrm{mM}$ Bicine buffer, $100 \mathrm{mM} \mathrm{KCl}, \mathrm{pH} 7.5$

$50 \mathrm{mM}$ Tris buffer, $100 \mathrm{mM} \mathrm{KCl}, \mathrm{pH} 8.5$

$50 \mathrm{mM}$ Bicine buffer, $100 \mathrm{mM} \mathrm{KCl}, \mathrm{pH} 8.5$

$50 \mathrm{mM}$ Tris buffer, $100 \mathrm{mM} \mathrm{KCl}, \mathrm{pH} 8.5$

$50 \mathrm{mM}$ Bicine buffer, $100 \mathrm{mM} \mathrm{KCl}, \mathrm{pH} 8.5$

$50 \mathrm{mM}$ Tris buffer, $100 \mathrm{mM} \mathrm{KCl}, \mathrm{pH} 8.5$

$50 \mathrm{mM}$ Bicine buffer, $100 \mathrm{mM} \mathrm{KCl}, \mathrm{pH} 8.5$

$50 \mathrm{mM}$ Tris buffer, $100 \mathrm{mM} \mathrm{KCl}, \mathrm{pH} 8.5$

$50 \mathrm{mM}$ Bicine buffer, $100 \mathrm{mM} \mathrm{KCl}$, pH 8.5

$50 \mathrm{mM}$ Tris buffer, $100 \mathrm{mM} \mathrm{KCl}, \mathrm{pH} 8.5$

$50 \mathrm{mM}$ Bicine buffer, $100 \mathrm{mM} \mathrm{KCl}, \mathrm{pH} 8.5$

$20 \mathrm{mM}$ NaHepes, $0.2 \mathrm{M} \mathrm{NaCl}$, pH 7.0

$20 \mathrm{mM}$ NaHepes, $0.2 \mathrm{M} \mathrm{NaCl}$, pH 7.0

$20 \mathrm{mM}$ NaHepes, $0.2 \mathrm{M} \mathrm{NaCl}$, pH 7.0

$20 \mathrm{mM}$ NaHepes, $0.2 \mathrm{M} \mathrm{NaCl}$, pH 7.0

$20 \mathrm{mM}$ NaHepes, $0.2 \mathrm{M} \mathrm{NaCl}$, pH 7.0

$20 \mathrm{mM}$ NaHepes, $0.2 \mathrm{M} \mathrm{NaCl}$, pH 7.0

$20 \mathrm{mM}$ NaHepes, $0.2 \mathrm{M} \mathrm{NaCl}$, pH 7.0

$20 \mathrm{mM}$ MES, $0.2 \mathrm{M} \mathrm{NaCl}$, pH 6.0

$20 \mathrm{mM}$ NaPhosphate, $0.2 \mathrm{M} \mathrm{NaCl}, \mathrm{pH} 6.5$

$20 \mathrm{mM}$ NaHepes, $0.2 \mathrm{M} \mathrm{NaCl}$, pH 7.5

$20 \mathrm{mM}$ NaHepes, $0.2 \mathrm{M} \mathrm{NaCl}$, pH 8.0

$20 \mathrm{mM}$ NaHepes, $0.2 \mathrm{M} \mathrm{NaCl}$, pH 8.0

$20 \mathrm{mM}$ Hepes, $200 \mathrm{mM} \mathrm{NaCl}, \mathrm{pH}$ 7.0, $1 \mathrm{mM}$ L-Phe

$20 \mathrm{mM}$ Hepes, $200 \mathrm{mM} \mathrm{NaCl}$, pH 7.0, 1mM L-Phe

$10 \mathrm{mM}$ Na-phosphate Buffer, $\%$ DMSO, $1 \mathrm{mM}$ EDTA, and 1\%

Glycerol, $0.5 \mathrm{mM}$ NAD+, pH 7.5

$10 \mathrm{mM}$ Na-phosphate Buffer, 2\% DMSO, $1 \mathrm{mM}$ EDTA, and 1\%

Glycerol, 0.5 mM NAD+, pH 7.5

\begin{tabular}{llll}
-36.8 & -184.5 & -147.7 & 70 \\
-35.6 & -39.3 & -3.8 & 70 \\
-34.7 & -79.5 & -44.8 & 70 \\
-39.3 & -34.3 & 5.0 & 70 \\
-38.1 & -73.2 & -35.1 & 70 \\
-39.3 & -38.1 & 1.3 & 70 \\
-37.2 & -78.2 & -41.0 & 70 \\
-26.4 & -20.1 & 6.3 & 70 \\
-27.2 & -63.2 & -36.0 & 70 \\
-38.9 & -48.5 & -9.6 & 70 \\
-37.2 & -54.0 & -16.7 & 70 \\
-41.0 & -51.0 & -10.0 & 70 \\
-38.9 & -95.8 & -56.9 & 70 \\
-40.6 & -48.1 & -7.5 & 70 \\
-41.0 & -78.7 & -37.7 & 70 \\
-36.4 & -43.9 & -7.5 & 70 \\
-37.2 & -92.5 & -55.2 & 70 \\
-27.2 & -15.5 & 11.7 & 70 \\
-27.2 & -72.0 & -44.8 & 70 \\
-29.7 & -35.6 & -5.4 & 70 \\
-31.8 & -109.6 & -77.8 & 70 \\
-29.3 & -29.3 & -0.4 & 70 \\
-31.0 & -106.3 & -75.3 & 70 \\
-37.2 & -46.4 & -9.2 & 70 \\
-40.2 & -129.3 & -89.1 & 70 \\
-32.6 & -45.6 & -13.0 & 70 \\
-33.9 & -116.3 & -82.4 & 70 \\
-33.1 & -23.8 & 9.1 & 71 \\
-34.5 & -33.8 & 0.8 & 71 \\
-35.0 & -49.3 & -14.3 & 71 \\
-35.2 & -68.8 & -33.6 & 71 \\
-28.2 & -9.0 & 19.1 & 71 \\
-27.3 & -14.0 & 13.3 & 71 \\
-28.7 & -15.5 & 13.2 & 71 \\
-29.4 & -40.8 & -11.8 & 71 \\
-33.8 & -42.8 & -8.9 & 71 \\
-33.9 & -41.3 & -7.4 & 71 \\
-35.7 & -43.9 & -8.1 & 71 \\
-27.8 & -12.7 & 15.1 & 71 \\
-31.8 & -27.7 & 4.1 & 71 \\
-27.6 & -7.7 & 19.8 & 71 \\
-41.7 & -42.5 & -0.7 & 72 \\
& & & \\
-40.8 & -56.9 & -15.9 & 72 \\
& & & \\
\hline
\end{tabular}

$-40.8$

$-56.9$ 
wt FabI/ PD048890

wt FabI/ PD048890

wt FabI/ PD0200828

wt FabI/ PD200828

wt FabI/ PD200828

wt FabI/ PD2002165

wt FabI/ PD2002165

wt FabI/ PD2002165

wt FabI/ PD205405

wt FabI/ PD205405

wt FabI/ PD205405

\section{BSA/ desflurane}

$\mathrm{BSA} /$ isoflurane

BSA/ enflurane

BSA/halothane

BSA/sevoflurane

HSA/ desflurane

HSA/ isoflurane

HSA/ enflurane

HSA/halothane

HSA/sevoflurane

Disabled-1 PTB native/ PI-4,5P2

Disabled-1 PTB mutant H81A/ PI-4,5P2

Disabled-1 PTB mutant H81Q/ PI-4,5P2

Disabled-1 PTB mutant S114Y/ PI-4,5P2

Disabled-1 PTB mutant F158V/ PI-4,5P2

HAS/ Sodium Penicillins Cloxacillin, first binding

HAS/ Sodium Penicillins Cloxacillin, second

binding

HSA/ Sodium Penicillins Cloxacillin, first binding

HSA/ Sodium Penicillins Cloxacillin, second

binding

HSA/ Sodium Penicillins Dicloxacillin, first

binding
$10 \mathrm{mM}$ Na-phosphate Buffer, 2\% DMSO, 1 mM EDTA, and 1\% Glycerol, 0.5 mM NAD+, pH 7.5

$10 \mathrm{mM}$ Na-phosphate Buffer, 2\% DMSO, $1 \mathrm{mM}$ EDTA, and 1\% Glycerol, $0.5 \mathrm{mM}$ NAD+, pH 7.5

$10 \mathrm{mM}$ Na-phosphate Buffer, 2\% DMSO, $1 \mathrm{mM}$ EDTA, and 1\% Glycerol, 0.5 mM NAD+, pH 7.5

$10 \mathrm{mM}$ Na-phosphate Buffer, 2\% DMSO, $1 \mathrm{mM}$ EDTA, and 1\% Glycerol, $0.5 \mathrm{mM} \mathrm{NAD}+$, $\mathrm{pH} 7.5$

$10 \mathrm{mM}$ Na-phosphate Buffer, 2\% DMSO, $1 \mathrm{mM}$ EDTA, and 1\% Glycerol, 0.5 mM NAD+, pH 7.5

$10 \mathrm{mM}$ Na-phosphate Buffer, 2\% DMSO, $1 \mathrm{mM}$ EDTA, and 1\% Glycerol, $0.5 \mathrm{mM}$ NAD+, $\mathrm{pH} 7.5$

$10 \mathrm{mM}$ Na-phosphate Buffer, 2\% DMSO, 1 mM EDTA, and 1\% Glycerol, 0.5 mM NAD+, pH 7.5

$10 \mathrm{mM}$ Na-phosphate Buffer, 2\% DMSO, $1 \mathrm{mM}$ EDTA, and 1\% Glycerol, $0.5 \mathrm{mM} \mathrm{NAD+}$, $\mathrm{pH} 7.5$

$10 \mathrm{mM}$ Na-phosphate Buffer, 2\% DMSO, $1 \mathrm{mM}$ EDTA, and 1\% Glycerol, 0.5 mM NAD+, pH 7.5

$10 \mathrm{mM}$ Na-phosphate Buffer, 2\% DMSO, $1 \mathrm{mM}$ EDTA, and 1\% Glycerol, 0.5 mM NAD+, pH 7.5

$10 \mathrm{mM}$ Na-phosphate Buffer, 2\% DMSO, $1 \mathrm{mM}$ EDTA, and 1\% Glycerol, 0.5 mM NAD+, pH 7.5

$150 \mathrm{mM} \mathrm{NaCl}$ and $10 \mathrm{mM}$ HEPES at $\mathrm{pH} 7.2$

$150 \mathrm{mM} \mathrm{NaCl}$ and $10 \mathrm{mM}$ HEPES at $\mathrm{pH} 7.2$

$150 \mathrm{mM} \mathrm{NaCl}$ and $10 \mathrm{mM}$ HEPES at $\mathrm{pH} 7.2$

$150 \mathrm{mM} \mathrm{NaCl}$ and $10 \mathrm{mM}$ HEPES at $\mathrm{pH} 7.2$

$150 \mathrm{mM} \mathrm{NaCl}$ and $10 \mathrm{mM}$ HEPES at $\mathrm{pH} 7.2$

$150 \mathrm{mM} \mathrm{NaCl}$ and $10 \mathrm{mM}$ HEPES at $\mathrm{pH} 7.2$

$150 \mathrm{mM} \mathrm{NaCl}$ and $10 \mathrm{mM}$ HEPES at $\mathrm{pH} 7.2$

$150 \mathrm{mM} \mathrm{NaCl}$ and $10 \mathrm{mM}$ HEPES at $\mathrm{pH} 7.2$

$150 \mathrm{mM} \mathrm{NaCl}$ and $10 \mathrm{mM}$ HEPES at $\mathrm{pH} 7.2$

$150 \mathrm{mM} \mathrm{NaCl}$ and $10 \mathrm{mM}$ HEPES at $\mathrm{pH} 7.2$

$20 \mathrm{mM}$ PIPES buffer, $150 \mathrm{mM} \mathrm{NaCl}, 0.2 \mathrm{mM}$ DTT, pH 7.0

$20 \mathrm{mM}$ PIPES buffer, $150 \mathrm{mM} \mathrm{NaCl}, 0.2 \mathrm{mM}$ DTT, pH 7.0

$20 \mathrm{mM}$ PIPES buffer, $150 \mathrm{mM} \mathrm{NaCl}, 0.2 \mathrm{mM}$ DTT, pH 7.0

$20 \mathrm{mM}$ PIPES buffer, $150 \mathrm{mM} \mathrm{NaCl}, 0.2 \mathrm{mM}$ DTT, pH 7.0

$20 \mathrm{mM}$ PIPES buffer, $150 \mathrm{mM} \mathrm{NaCl}, 0.2 \mathrm{mM}$ DTT, pH 7.0

Aqueous Buffered Solutions, $\mathrm{pH} 4.5$

Aqueous Buffered Solutions, $\mathrm{pH} 4.5$

Aqueous Buffered Solutions, pH 7.4

Aqueous Buffered Solutions, pH 7.4

Aqueous Buffered Solutions, $\mathrm{pH} 4.5$

\begin{tabular}{|c|c|c|c|}
\hline 25 & -39.0 & -84.9 & -45.8 \\
\hline 30 & -40.5 & -95.0 & -54.5 \\
\hline 20 & -46.6 & -72.8 & -26.1 \\
\hline 25 & -45.8 & -81.2 & -35.4 \\
\hline 30 & -46.5 & -106.3 & -59.8 \\
\hline 25 & -50.2 & -73.2 & -23.1 \\
\hline 27.5 & -49.5 & -88.3 & -38.8 \\
\hline 30 & -48.2 & -98.3 & -50.1 \\
\hline 25 & -49.0 & -68.7 & -19.8 \\
\hline 27.5 & -46.0 & -81.6 & -35.6 \\
\hline 30 & -48.8 & -93.3 & -44.5 \\
\hline 20 & -19.3 & -12.7 & 6.6 \\
\hline 20 & -17.5 & -16.5 & 1.0 \\
\hline 20 & -16.6 & -25.0 & -8.4 \\
\hline 20 & -14.6 & -26.1 & -11.5 \\
\hline 20 & -13.6 & -18.0 & -4.4 \\
\hline 20 & -20.0 & -15.4 & 4.6 \\
\hline 20 & -18.5 & -15.6 & 2.9 \\
\hline 20 & -17.8 & -22.0 & -4.2 \\
\hline 20 & -14.9 & -20.4 & -5.5 \\
\hline 20 & -15.1 & -7.1 & 7.9 \\
\hline 25 & -33.8 & -80.3 & -46.4 \\
\hline 25 & -26.4 & -46.9 & -19.2 \\
\hline 25 & -27.1 & -41.0 & -14.2 \\
\hline 25 & -33.8 & -102.1 & -68.2 \\
\hline 25 & -35.5 & -75.7 & -40.2 \\
\hline 25 & -21.7 & -0.4 & 21.3 \\
\hline 25 & -19.1 & -0.1 & 19.0 \\
\hline 25 & -20.5 & -0.1 & 20.4 \\
\hline 25 & -16.6 & -0.1 & 16.5 \\
\hline 25 & -22.3 & -0.3 & 22.0 \\
\hline
\end{tabular}


HSA/ Sodium Penicillins Dicloxacillin, second binding

HSA/ Sodium Penicillins Dicloxacillin, first binding

HSA/ Sodium Penicillins Dicloxacillin, second binding

S. japonicum-GST/ ANS

S. japonicum-GST/ ANS

S. japonicum-GST/ ANS

S. japonicum-GST/ ANS

S. japonicum-GST/ BS

S. japonicum-GST/ BS

S. japonicum-GST/BS

S. japonicum-GST/ BS

Wild-Type HasASM/ Heme

H32A Mutated HasASM/ Heme

Y75A Mutated HasASM/ Heme

H83A Mutated HasASM/ Heme

83Q Mutated HasASM/ Heme

H32A-Y75A Mutated HasASM/ Heme

H32A-H83A Mutated HasASM/ Heme

H32A-H83Q Mutated HasASM/ Heme

Y75A-H83 A Mutated Has ASM/ Heme

Y75A-H83Q Mutated HasASM/ Heme

Glycyl-tRNA Synthetase/ ATP

Glycyl-tRNA Synthetase/ AMPPNP

Glycyl-tRNA Synthetase/ AMPPCP

Glycyl-tRNA Synthetase/ GSAd

MAP2C/ DHEA

MAP2C/ DHEA

Human AAG/ Indinavir

Human AAG/Saquinavir

Human AAG/ KNI-764

Human AAG/ Nelfinavir

Human AAG/ Ritonavir

Trypsin/ p-Alkylbenzamidinium Chlorides

Trypsin/ p-Alkylbenzamidinium Chlorides

Trypsin/Me- p-Alkylbenzamidinium Chlorides

Trypsin/Me- p-Alkylbenzamidinium Chlorides

Trypsin/Et- p-Alkylbenzamidinium Chlorides

Trypsin/ Et-p-Alkylbenzamidinium Chlorides

Trypsin/nPr-p-Alkylbenzamidinium Chlorides

Trypsin/nPr-p-Alkylbenzamidinium Chlorides

Trypsin/ iPr-p-Alkylbenzamidinium Chlorides

Trypsin/ i-Pr-p-Alkylbenzamidinium Chlorides
Aqueous Buffered Solutions, pH 4.5

Aqueous Buffered Solutions, $\mathrm{pH} 7.4$

Aqueous Buffered Solutions, pH 7.4

standard phosphate buffer, $\mathrm{pH} 6.5$

standard phosphate buffer, $\mathrm{pH} 6.5$

standard phosphate buffer, $\mathrm{pH} 6.5$

standard phosphate buffer, pH 6.5

standard phosphate buffer, $\mathrm{pH} 6.5$

standard phosphate buffer, $\mathrm{pH} 6.5$

standard phosphate buffer, $\mathrm{pH} 6.5$

standard phosphate buffer, $\mathrm{pH} 6.5$

Sodium Phosphate Buffer, $\mathrm{pH} 7.3$

Sodium Phosphate Buffer, $\mathrm{pH} 7.3$

Sodium Phosphate Buffer, pH 7.3

Sodium Phosphate Buffer, $\mathrm{pH} 7.3$

Sodium Phosphate Buffer, $\mathrm{pH} 7.3$

Sodium Phosphate Buffer, pH 7.3

Sodium Phosphate Buffer, pH 7.3

Sodium Phosphate Buffer, $\mathrm{pH} 7.3$

Sodium Phosphate Buffer, $\mathrm{pH} 7.3$

Sodium Phosphate Buffer, pH 7.3

$20 \mathrm{mM}$ HEPES-KOH, $5 \mathrm{mM} \mathrm{MgCl} 2,0.5 \mathrm{mM}$ DTT, $50 \mathrm{mM} \mathrm{NaCl}, \mathrm{pH} 7.2$

$20 \mathrm{mM}$ HEPES-KOH, $5 \mathrm{mM} \mathrm{MgCl} 2,0.5 \mathrm{mM}$ DTT, $50 \mathrm{mM} \mathrm{NaCl}, \mathrm{pH} 7.2$

$20 \mathrm{mM}$ HEPES-KOH, $5 \mathrm{mM} \mathrm{MgCl} 2,0.5 \mathrm{mM}$ DTT, $50 \mathrm{mM} \mathrm{NaCl}, \mathrm{pH} 7.2$

$20 \mathrm{mM}$ HEPES-KOH, $5 \mathrm{mM} \mathrm{MgCl}$, $0.5 \mathrm{mM}$ DTT, $50 \mathrm{mM} \mathrm{NaCl}$, pH 7.2

$50 \mathrm{mM}$ MES, pH 6.8

$50 \mathrm{mM}$ phosphate buffer, $\mathrm{pH} 7.5$

$10 \mathrm{mM}$ sodium acetate, $2 \%$ DMSO, $\mathrm{pH} 5.0$

$10 \mathrm{mM}$ sodium acetate, 2\% DMSO, $\mathrm{pH} 5.0$

$10 \mathrm{mM}$ sodium acetate, $2 \%$ DMSO, $\mathrm{pH} 5.0$

$10 \mathrm{mM}$ sodium acetate, $2 \%$ DMSO, $\mathrm{pH} 5.0$

$10 \mathrm{mM}$ sodium acetate, $2 \%$ DMSO, pH 5.0

$50 \mathrm{mM}$ Tris, $10 \mathrm{mM} \mathrm{CaCl}_{2}$ buffer at $\mathrm{pH} 8.0$

$50 \mathrm{mM}$ Tris, $10 \mathrm{mM} \mathrm{CaCl}_{2}$ buffer at $\mathrm{pH} 8.0$

$50 \mathrm{mM}$ Tris, $10 \mathrm{mM} \mathrm{CaCl}_{2}$ buffer at $\mathrm{pH} 8.0$

$50 \mathrm{mM}$ Tris, $10 \mathrm{mM} \mathrm{CaCl}_{2}$ buffer at $\mathrm{pH} 8.0$

$50 \mathrm{mM}$ Tris, $10 \mathrm{mM} \mathrm{CaCl}_{2}$ buffer at $\mathrm{pH} 8.0$

$50 \mathrm{mM}$ Tris, $10 \mathrm{mM} \mathrm{CaCl}_{2}$ buffer at $\mathrm{pH} 8.0$

$50 \mathrm{mM}$ Tris, $10 \mathrm{mM} \mathrm{CaCl}_{2}$ buffer at $\mathrm{pH} 8.0$

$50 \mathrm{mM}$ Tris, $10 \mathrm{mM} \mathrm{CaCl}_{2}$ buffer at $\mathrm{pH} 8.0$

Tris, $10 \mathrm{mM} \mathrm{CaCl}_{2}$ buffer at $\mathrm{pH} 8.0$

$50 \mathrm{mM}$ Tris, $10 \mathrm{mM} \mathrm{CaCl}_{2}$ buffer at $\mathrm{pH} 8.0$

\begin{tabular}{lllll}
25 & -19.5 & -0.1 & 19.4 & 75 \\
25 & -21.0 & -0.1 & 20.9 & 75 \\
& & & & \\
25 & -17.5 & -0.1 & 17.4 & 75 \\
& & & & \\
25 & -20.0 & -52.4 & -32.4 & 76 \\
30 & -19.9 & -57.2 & -37.2 & 76 \\
35 & -20.0 & -64.8 & -44.8 & 76 \\
40 & -20.2 & -70.3 & -50.1 & 76 \\
25 & -30.2 & -12.0 & 18.2 & 76 \\
30 & -29.5 & -29.1 & 0.5 & 76 \\
35 & -30.7 & -38.7 & -8.1 & 76 \\
40 & -33.5 & -49.0 & -15.6 & 76 \\
25 & -61.1 & -105.4 & -44.3 & 77 \\
25 & -57.1 & -72.2 & -15.1 & 77 \\
25 & -46.4 & -74.4 & -28.0 & 77 \\
25 & -47.3 & -62.2 & -14.9 & 77 \\
25 & -48.7 & -89.1 & -40.4 & 77 \\
25 & -27.2 & -25.8 & -1.4 & 77 \\
25 & -42.0 & -41.1 & -0.9 & 77 \\
25 & -42.3 & -29.2 & 13.1 & 77 \\
25 & -35.7 & -35.0 & 0.6 & 77 \\
25 & -36.9 & -54.0 & -17.0 & 77 \\
25 & -30.6 & -72.0 & -36.9 & 78 \\
25 & -31.7 & -68.0 & -38.9 & 78 \\
25 & -36.3 & -70.7 & -31.7 & 78 \\
25 & -37.4 & -187 & -149 & 78 \\
25 & -42.0 & -34.0 & 8.0 & 79 \\
25 & -40.0 & -10.0 & 30.0 & 79 \\
35 & -26.9 & -7.5 & 19.4 & 80 \\
25 & -30.7 & -60.7 & -30.0 & 80 \\
25 & -33.3 & -28.9 & 4.4 & 80 \\
25 & -33.4 & -22.2 & 11.2 & 80 \\
25 & -34.9 & -24.7 & 10.2 & 80 \\
20 & -26.9 & -17.0 & 9.9 & 81 \\
37 & -26.7 & -23.7 & 3.0 & 81 \\
20 & -27.5 & -16.7 & 10.8 & 81 \\
37 & -27.4 & -23.8 & 3.6 & 81 \\
20 & -25.5 & -10.6 & 14.9 & 81 \\
37 & -25.6 & -22.4 & 3.2 & 81 \\
20 & -25.7 & -9.7 & 16.0 & 81 \\
37 & -25.6 & -19.9 & 5.7 & 81 \\
20 & -22.6 & -4.9 & 18 & 81 \\
37 & -22.7 & -12.0 & 11 & 81 \\
\hline & & & &
\end{tabular}


Trypsin/nBu-p-Alkylbenzamidinium Chlorides Trypsin/ nBu-p-Alkylbenzamidinium Chlorides Trypsin/nPent- p-Alkylbenzamidinium Chlorides Trypsin/nPent-p-Alkylbenzamidinium Chlorides Trypsin/nHex-p-Alkylbenzamidinium Chlorides Trypsin/ nHex-p-Alkylbenzamidinium Chlorides Anti-NP antibody N1G9/NP-Cap Anti-NP antibody N1G9/NP-Cap Anti-NP antibody N1G9/NP-Cap Anti-NP antibody N1G9/NP-Cap Anti-NP antibody N1G9/NP-Cap Anti-NP antibody N1G9/NP-Cap Anti-NP antibody 3B44/NP-Cap Anti-NP antibody 3B44/NP-Cap Anti-NP antibody 3B44/NP-Cap Anti-NP antibody 3B44/NP-Cap Anti-NP antibody 3B44/NP-Cap Anti-NP antibody 3B44/NP-Cap Anti-NP antibody 3B62/NP-Cap Anti-NP antibody 3B62/NP-Cap Anti-NP antibody 3B62/NP-Cap Anti-NP antibody 3B62/NP-Cap Anti-NP antibody 3B62/NP-Cap Anti-NP antibody 3B62/NP-Cap
$50 \mathrm{mM}$ Tris, $10 \mathrm{mM} \mathrm{CaCl}_{2}$ buffer at $\mathrm{pH} 8.0$

$50 \mathrm{mM}$ Tris, $10 \mathrm{mM} \mathrm{CaCl}_{2}$ buffer at $\mathrm{pH} 8.0$

$50 \mathrm{mM}$ Tris, $10 \mathrm{mM} \mathrm{CaCl}_{2}$ buffer at $\mathrm{pH} 8.0$

$50 \mathrm{mM}$ Tris, $10 \mathrm{mM} \mathrm{CaCl}_{2}$ buffer at $\mathrm{pH} 8.0$

$50 \mathrm{mM}$ Tris, $10 \mathrm{mM} \mathrm{CaCl}_{2}$ buffer at $\mathrm{pH} 8.0$

$50 \mathrm{mM}$ Tris, $10 \mathrm{mM} \mathrm{CaCl}_{2}$ buffer at $\mathrm{pH} 8.0$

$5 \mathrm{mM}$ sodium phosphate buffer, $200 \mathrm{mM} \mathrm{NaCl}, \mathrm{pH} 8.0$

$5 \mathrm{mM}$ sodium phosphate buffer, $200 \mathrm{mM} \mathrm{NaCl}, \mathrm{pH} 8.0$

$5 \mathrm{mM}$ sodium phosphate buffer, $200 \mathrm{mM} \mathrm{NaCl}, \mathrm{pH} 8.0$

$5 \mathrm{mM}$ sodium phosphate buffer, $200 \mathrm{mM} \mathrm{NaCl}$, pH 8.0

$5 \mathrm{mM}$ sodium phosphate buffer, $200 \mathrm{mM} \mathrm{NaCl}, \mathrm{pH} 8.0$

$5 \mathrm{mM}$ sodium phosphate buffer, $200 \mathrm{mM} \mathrm{NaCl}, \mathrm{pH} 8.0$

$5 \mathrm{mM}$ sodium phosphate buffer, $200 \mathrm{mM} \mathrm{NaCl}$, pH 8.0

$5 \mathrm{mM}$ sodium phosphate buffer, $200 \mathrm{mM} \mathrm{NaCl}$, pH 8.0

$5 \mathrm{mM}$ sodium phosphate buffer, $200 \mathrm{mM} \mathrm{NaCl}, \mathrm{pH} 8.0$

$5 \mathrm{mM}$ sodium phosphate buffer, $200 \mathrm{mM} \mathrm{NaCl}$, pH 8.0

$5 \mathrm{mM}$ sodium phosphate buffer, $200 \mathrm{mM} \mathrm{NaCl}, \mathrm{pH} 8.0$

$5 \mathrm{mM}$ sodium phosphate buffer, $200 \mathrm{mM} \mathrm{NaCl}, \mathrm{pH} 8.0$

$5 \mathrm{mM}$ sodium phosphate buffer, $200 \mathrm{mM} \mathrm{NaCl}, \mathrm{pH} 8.0$

$5 \mathrm{mM}$ sodium phosphate buffer, $200 \mathrm{mM} \mathrm{NaCl}, \mathrm{pH} 8.0$

$5 \mathrm{mM}$ sodium phosphate buffer, $200 \mathrm{mM} \mathrm{NaCl}$, pH 8.0

$5 \mathrm{mM}$ sodium phosphate buffer, $200 \mathrm{mM} \mathrm{NaCl}$, pH 8.0

$5 \mathrm{mM}$ sodium phosphate buffer, $200 \mathrm{mM} \mathrm{NaCl}, \mathrm{pH} 8.0$

$5 \mathrm{mM}$ sodium phosphate buffer, $200 \mathrm{mM} \mathrm{NaCl}, \mathrm{pH} 8.0$

Table S4. Thermodynamic Parameters for Some Protein-Peptide Interactions

\begin{tabular}{|c|c|c|c|c|c|c|}
\hline Complex & Solvent & $\begin{array}{ll}T & / \\
{ }^{\circ} \mathrm{C} & \\
\end{array}$ & $\begin{array}{l}\Delta G / \\
\mathrm{kJ} \mathrm{mol}^{-1}\end{array}$ & $\begin{array}{l}\Delta H / \\
\mathrm{kJ} \mathrm{mol}^{-1}\end{array}$ & $\begin{array}{l}T \Delta S / \\
\mathrm{kJ} \mathrm{mol}^{-1}\end{array}$ & Ref. \\
\hline nGLP1R/GLP-1 & $0.25 \mathrm{M}$ L-arginine, $50 \mathrm{mM}$ phosphate, $1 \mathrm{mM}$ EDTA, $\mathrm{pH} 7.3$ & 20 & -38.4 & -102.5 & -64.1 & 83 \\
\hline Fibrinogen/S-nitrosoglutathione & Phosphate buffered saline, $\mathrm{pH} 7.4$ & 25 & -31.3 & 46.9 & 79.5 & 84 \\
\hline Nematode anticoagulant protein $\mathrm{c} 2 /$ factor $\mathrm{X}$ & $20 \mathrm{mM}$ hepes, $0.15 \mathrm{M} \mathrm{NaCl}, 2.0 \mathrm{mM} \mathrm{Ca}^{2+}, \mathrm{pH} 7.4$ & 25 & -51.7 & -57.8 & -6.1 & 85 \\
\hline Nematode anticoagulant protein $\mathrm{c} 2 /$ factor $\mathrm{X}$ & $20 \mathrm{mM}$ hepes, $0.15 \mathrm{M} \mathrm{NaCl}$, pH 7.4 & 25 & -50.2 & -57.1 & -6.9 & 85 \\
\hline Nematode anticoagulant protein $\mathrm{c} 2 /$ factor $\mathrm{Xa}$ & $20 \mathrm{mM}$ hepes, $0.15 \mathrm{M} \mathrm{NaCl}, 2.0 \mathrm{mM} \mathrm{Ca}^{2+}, \mathrm{pH} 7.4$ & 25 & -52.0 & -71.5 & -65.6 & 85 \\
\hline Calmodulin/nitric oxide synthase I peptide & $\begin{array}{l}10 \mathrm{mM} \text { hepes, } 150 \mathrm{mM} \mathrm{NaCl}, 10 \mathrm{mM} \mathrm{MgCl} \\
0.005 \% \text { Tween } 20 \text {, } \mathrm{pH} 7.4\end{array}$ & 25 & -41.1 & -30.4 & 10.8 & 86 \\
\hline Src homology $2 /$ phosphotyrosyl peptide inhibitor & $20 \mathrm{mM}$ hepes, $1 \mathrm{mM} \mathrm{HS}\left(\mathrm{CH}_{2}\right)_{2} \mathrm{OH}, 1 \mathrm{mM}$ EDTA, $100 \mathrm{mM} \mathrm{NaCl}, \mathrm{pH} 7.3$ & 25 & -37.7 & -25.4 & 12.3 & 87 \\
\hline Src homology $2 /$ phosphotyrosyl peptide inhibitor & $20 \mathrm{mM}$ hepes, $1 \mathrm{mM} \mathrm{HS}\left(\mathrm{CH}_{2}\right)_{2} \mathrm{OH}, 1 \mathrm{mM}$ EDTA, $100 \mathrm{mM} \mathrm{NaCl}$, pH 7.3 & 25 & -40 & -24.7 & 21.2 & 87 \\
\hline Src homology $2 /$ phosphotyrosyl peptide inhibitor & $20 \mathrm{mM}$ hepes, $1 \mathrm{mM} \mathrm{HS}\left(\mathrm{CH}_{2}\right)_{2} \mathrm{OH}, 1 \mathrm{mM}$ EDTA, $100 \mathrm{mM} \mathrm{NaCl}$, pH 7.3 & 25 & -41 & -30.7 & 10.4 & 87 \\
\hline Src homology $2 /$ phosphotyrosyl peptide inhibitor & $20 \mathrm{mM}$ hepes, $1 \mathrm{mM} \mathrm{HS}\left(\mathrm{CH}_{2}\right)_{2} \mathrm{OH}, 1 \mathrm{mM}$ EDTA, $100 \mathrm{mM} \mathrm{NaCl}$, pH 7.3 & 25 & -38.7 & -21 & 17.8 & 87 \\
\hline Src homology $2 /$ phosphotyrosyl peptide inhibitor & $20 \mathrm{mM}$ hepes, $1 \mathrm{mM} \mathrm{HS}\left(\mathrm{CH}_{2}\right)_{2} \mathrm{OH}, 1 \mathrm{mM}$ EDTA, $100 \mathrm{mM} \mathrm{NaCl}$, pH 7.3 & 25 & -40.7 & -29 & 11.7 & 87 \\
\hline Human protein $\mathrm{S} 100 \mathrm{P} /$ melittin & $50 \mathrm{mM}$ Tris, $0.2 \mathrm{mM}$ EDTA, $1.5 \mathrm{mM}$ TCEP, $\mathrm{pH} 7.5$ & 25 & -21.4 & 63 & 84.4 & 88 \\
\hline Dihydrolipoyl dehydrogenase/PSBD & 10 mM Hepes, 150 mM NaCl, 3.4 mM EDAT, pH 7.4 & 25 & -52.7 & 9.2 & 61.9 & 89 \\
\hline
\end{tabular}




\begin{tabular}{|c|c|c|c|c|c|c|}
\hline $\begin{array}{l}\text { dihydrolipoyl acetyltransferase } \\
\text { Pyruvate decarboxylase/ PSBD of dihydrolipoyl } \\
\text { acetyltransferase }\end{array}$ & 10 mM Hepes, 150 mM NaCl, 3.4 mM EDAT, pH 7.4 & 25 & -54.0 & -35.1 & 18.8 & 89 \\
\hline FRS2 $\alpha$ PTB domain/FGFR1 peptide & 20 mM Tris- $\mathrm{HCl}, \mathrm{pH} 8.0$ & 25 & -27.6 & -5.0 & 22.6 & 90 \\
\hline FRS $2 \alpha$ PTB domain/FGFR1 peptide & $50 \mathrm{mM}$ phosphate, $200 \mathrm{mM} \mathrm{NaCl}, 1 \mathrm{mM}$ EDTA, $5 \mathrm{mM} \mathrm{HS}\left(\mathrm{CH}_{2}\right)_{2} \mathrm{OH}, \mathrm{pH} 7.0$ & 25 & -28.5 & -7.5 & 20.9 & 90 \\
\hline FRS2 $\alpha$ PTB domain/TRKB, pY61 peptide & $20 \mathrm{mM}$ Tris- $\mathrm{HCl}, \mathrm{pH} 8.0$ & 25 & -28.9 & -20.1 & 8.8 & 90 \\
\hline FRS2 $\alpha$ PTB domain/TRKB, pY61 peptide & $50 \mathrm{mM}$ phosphate, $200 \mathrm{mM} \mathrm{NaCl}, 1 \mathrm{mM}$ EDTA,5 mM HS$\left(\mathrm{CH}_{2}\right)_{2} \mathrm{OH}, \mathrm{pH} 7.0$ & 25 & -30.1 & -33.5 & -3.3 & 90 \\
\hline FRS $2 \alpha$ PTB domain/TRKA, pY490 peptide & $20 \mathrm{mM}$ Tris- $\mathrm{HCl}, \mathrm{pH} 8.0$ & 25 & -27.2 & -20.9 & 6.3 & 90 \\
\hline FRS $2 \alpha$ PTB domain/TRKA, pY490 peptide & $50 \mathrm{mM}$ phosphate, $200 \mathrm{mM} \mathrm{NaCl}, 1 \mathrm{mM}$ EDTA, $5 \mathrm{mM} \mathrm{HS}\left(\mathrm{CH}_{2}\right)_{2} \mathrm{OH}, \mathrm{pH} 7.0$ & 25 & -29.3 & -27.2 & 2.1 & 90 \\
\hline FRS2 $\alpha$ PTB domain/TRKA (A-5) peptide & $20 \mathrm{mM}$ Tris- $\mathrm{HCl}, \mathrm{pH} 8.0$ & 25 & -25.5 & -19.7 & 5.4 & 90 \\
\hline FRS $2 \alpha$ PTB domain/TRKA (A-5) peptide & $50 \mathrm{mM}$ phosphate, $200 \mathrm{mM} \mathrm{NaCl}, 1 \mathrm{mM}$ EDTA, $5 \mathrm{mM} \mathrm{HS}\left(\mathrm{CH}_{2}\right)_{2} \mathrm{OH}, \mathrm{pH} 7.0$ & 25 & -26.4 & -23.0 & 3.3 & 90 \\
\hline FRS $2 \alpha$ PTB domain/IL-4R, pY497 peptide & $20 \mathrm{mM}$ Tris- $\mathrm{HCl}, \mathrm{pH} 8.0$ & 25 & -34.3 & -43.1 & -8.8 & 90 \\
\hline $\operatorname{SOCS} 3(\Delta 101-133) /$ gp130 peptide & $\begin{array}{l}50 \mathrm{~mm} \mathrm{NaCl}, 50 \mathrm{~mm} \text { arginine, } 50 \mathrm{~mm} \text { glutamate, } 5 \mathrm{~mm} \mathrm{2-} \\
\text { mercaptoethanol, } \mathrm{pH} 6.7\end{array}$ & 25 & -40.6 & -27.0 & 13.6 & 91 \\
\hline Wild type SOCS3/gp130 peptide & $\begin{array}{l}50 \mathrm{~mm} \mathrm{NaCl}, 50 \mathrm{~mm} \text { arginine, } 50 \mathrm{~mm} \text { glutamate, } 5 \mathrm{~mm} \mathrm{2-} \\
\text { mercaptoethanol, } \mathrm{pH} 6.7\end{array}$ & 25 & -38.7 & -25.9 & 12.7 & 91 \\
\hline Hemextin AB complex/ FVII $\alpha$ & $50 \mathrm{mM}$ Tris- $\mathrm{HCl}$ buffer and $10 \mathrm{mM} \mathrm{CaCl}_{2}, \mathrm{pH} 7.4$ & 37 & -33.3 & -33.2 & -1.6 & 92 \\
\hline Tetratricopeptide repeat domain/ MEEVD peptide & 50 mM Mes, 5 mM DTT, pH 6.0 & 10 & -40.6 & -33.0 & 7.6 & 93 \\
\hline Tetratricopeptide repeat domain/ MEEVD peptide & $50 \mathrm{mM}$ Mes, 5 mM DTT, pH 6.0 & 15 & -40.3 & -52.9 & -12.7 & 93 \\
\hline Tetratricopeptide repeat domain/ MEEVD peptide & $50 \mathrm{mM}$ Mes, 5 mM DTT, pH 6.0 & 17.5 & -39.3 & -63.4 & -24.1 & 93 \\
\hline Tetratricopeptide repeat domain/ MEEVD peptide & $50 \mathrm{mM}$ Mes, 5 mM DTT, pH 6.0 & 20 & -41.2 & -84.9 & -43.7 & 93 \\
\hline Tetratricopeptide repeat domain/ MEEVD peptide & $50 \mathrm{mM}$ Mes, $5 \mathrm{mM}$ DTT, pH 6.0 & 22.5 & -41.7 & -90.9 & -49.1 & 93 \\
\hline Tetratricopeptide repeat domain/ MEEVD peptide & $50 \mathrm{mM}$ Mes, 5 mM DTT, pH 6.0 & 25 & -41.4 & -144.7 & -73.3 & 93 \\
\hline Tetratricopeptide repeat domain/ MEEVD peptide & $50 \mathrm{mM}$ Mes, 5 mM DTT, pH 6.0 & 25 & -40.3 & -119.0 & -78.6 & 93 \\
\hline Tetratricopeptide repeat domain/ MEEVD peptide & $50 \mathrm{mM}$ Mes, 5 mM DTT, pH 6.0 & 27.5 & -42.2 & -123.7 & -81.4 & 93 \\
\hline Tetratricopeptide repeat domain/ MEEVD peptide & $50 \mathrm{mM}$ Mes, 5 mM DTT, pH 6.0 & 30 & -42.6 & -173.2 & -130.5 & 93 \\
\hline Tetratricopeptide repeat domain/ MEEVD peptide & $50 \mathrm{mM}$ Mes, 5 mM DTT, pH 6.0 & 32 & -39.8 & -177.7 & -137.9 & 93 \\
\hline Tetratricopeptide repeat domain/ MEEVD peptide & $50 \mathrm{mM}$ Mes, 5 mM DTT, pH 6.0 & 34 & -42.8 & -202.8 & -161.0 & 93 \\
\hline Tetratricopeptide repeat domain/ MEEVD peptide & $50 \mathrm{mM}$ Mes, 5 mM DTT, pH 6.0 & 36 & -41.1 & -219.9 & -178.8 & 93 \\
\hline SjGST(Y7F)/ S-methyl-GSH & $20 \mathrm{mM}$ MES, $2 \mathrm{mM}$ DTT, and $1 \mathrm{mM}$ EDTA, pH 6.5 & 25 & -26.2 & -19.2 & 7.0 & 94 \\
\hline SjGST(Y7F)/ S-methyl-GSH & $20 \mathrm{mM}$ MES, $2 \mathrm{mM}$ DTT, and $1 \mathrm{mM}$ EDTA, pH 6.5 & 30 & -25.5 & -26.5 & -1.0 & 94 \\
\hline SjGST(Y7F)/ S-methyl-GSH & $20 \mathrm{mM}$ MES, $2 \mathrm{mM}$ DTT, and $1 \mathrm{mM}$ EDTA, pH 6.5 & 35 & -24.5 & -32.4 & -7.9 & 94 \\
\hline SjGST(Y7F)/ S-hexyl-GSH & $20 \mathrm{mM}$ MES, $2 \mathrm{mM}$ DTT, and $1 \mathrm{mM}$ EDTA, pH 6.5 & 25 & -30.1 & -31.3 & -1.1 & 94 \\
\hline SjGST(Y7F)/ S-hexyl-GSH & $20 \mathrm{mM}$ MES, 2 mM DTT, and $1 \mathrm{mM}$ EDTA, pH 6.5 & 30 & -30.1 & -36.9 & -6.7 & 94 \\
\hline SjGST(Y7F)/ S-hexyl-GSH & $20 \mathrm{mM}$ MES, 2 mM DTT, and 1 mM EDTA, pH 6.5 & 35 & -30.7 & -42.4 & -11.7 & 94 \\
\hline SjGST(Y7F)/ S-octyl-GSH & $20 \mathrm{mM}$ MES, $2 \mathrm{mM}$ DTT, and $1 \mathrm{mM}$ EDTA, pH 6.5 & 20 & -32.2 & -27.9 & 4.3 & 94 \\
\hline SjGST(Y7F)/ S-octyl-GSH & $20 \mathrm{mM}$ MES, $2 \mathrm{mM}$ DTT, and $1 \mathrm{mM}$ EDTA, pH 6.5 & 25 & -32.5 & -30.4 & 2.1 & 94 \\
\hline SjGST(Y7F)/ S-octyl-GSH & $20 \mathrm{mM}$ MES, 2 mM DTT, and 1 mM EDTA, pH 6.5 & 30 & -32.8 & -33.5 & -0.7 & 94 \\
\hline SjGST(Y7F)/ S-octyl-GSH & $20 \mathrm{mM}$ MES, $2 \mathrm{mM}$ DTT, and $1 \mathrm{mM}$ EDTA, pH 6.5 & 35 & -32.5 & -38.1 & -5.6 & 94 \\
\hline FadR protein- E. coli/ Leoyl-CoA & $\begin{array}{l}20 \mathrm{mM} \text { Tris-HCl, } 50 \mathrm{mM} \text { NaCl, } 1 \mathrm{mM} \text { EDTA, } 0.1 \mathrm{mM} \text { Tris(2- } \\
\text { carboxyethyl)phosphine hydrochloride), } \mathrm{pH} 7.0\end{array}$ & 30 & -41.4 & -82.9 & -41.5 & 95 \\
\hline FadR protein- S. enterica/ Leoyl-CoA & $\begin{array}{l}20 \mathrm{mM} \text { Tris-HCl, 50mM NaCl, } 1 \mathrm{mM} \text { EDTA, } 0.1 \mathrm{mM} \text { Tris(2- } \\
\text { carboxyethyl)phosphine hydrochloride), } \mathrm{pH} 7.0\end{array}$ & 30 & -39.7 & -80.8 & -41.0 & 95 \\
\hline FadR protein- $V$. cholerae/ Leoyl-CoA & $20 \mathrm{mM}$ Tris- $\mathrm{HCl}, \quad 50 \mathrm{mM}$ NaCl, $1 \mathrm{mM}$ EDTA, $0.1 \mathrm{mM}$ Tris(2- & 30 & -44.0 & -49.0 & -5.0 & 95 \\
\hline
\end{tabular}


FadR protein- P. multocida/ Leoyl-CoA

FadR protein- $H$. influenzae/ Leoyl-CoA

Grb7-SH2/ erbB2 peptide pY1139

Molecular Chaperone, $\mathrm{ClpA}_{6} / \mathrm{SsrA}$ peptide Molecular Chaperone, $\mathrm{ClpA}_{6} / \mathrm{SsrA}$ peptide Molecular Chaperone, $\mathrm{ClpA}_{6} / \mathrm{SsrA}$ peptide Molecular Chaperone, $\mathrm{ClpA}_{6} / \mathrm{SsrA}$ peptide Molecular Chaperone, $\mathrm{ClpA}_{6} / \mathrm{SsrA}$ peptide Molecular Chaperone, $\mathrm{ClpA}_{6} / \mathrm{SsrA}$ peptide Molecular Chaperone, $\mathrm{ClpA}_{6} / \mathrm{SsrA}$ peptide Molecular Chaperone, $\mathrm{ClpA}_{\sigma} /$ DNS-SsrA peptide Molecular Chaperone, $\mathrm{ClpA}_{6} /$ DNS-SsrA peptide Molecular Chaperone, $\mathrm{ClpA}_{6} / \alpha \mathrm{SsrA}$ peptide Molecular Chaperone, $\mathrm{ClpA}_{6} / \alpha \mathrm{SsrA}$ peptide Molecular Chaperone, $\mathrm{ClpA}_{6} / \alpha \mathrm{SsrA}$ peptide $\mathrm{CaM} / \mathrm{RS} 20$ peptide

CaMox/ RS20 peptide

CaMox + MsrA/ RS20 peptide

CaMox + MsrB/ RS20 peptide

CaMox + MsrAB/ RS20 peptide

PDZ3 from PSD-95/ peptide 1

PDZ3 from PSD-95/ peptide 2

PDZ3 from PSD-95/ peptide 3

PDZ3 from PSD-95/ peptide 4

PDZ3 from PSD-95/ peptide 5

PDZ3 from PSD-95/ peptide 6

PDZ3 from PSD-95/ peptide 7

PDZ3 from PSD-95/ peptide 8

src homology 3 (SH3)/ peptide p1

src homology 3 (SH3)/ peptide p2

ApoCaM/ NOS-II V511K peptide

ApoCaM/ NOS-II F517K peptide

ApoCaM/ NOS-II M521K peptide

ApoCaM/ NOS-II 3K peptide

ApoCaM/ NOS-II E3K peptide

Ab1-SH3/ RP1 peptide carboxyethyl)phosphine hydrochloride), $\mathrm{pH} 7.0$

$20 \mathrm{mM}$ Tris- $\mathrm{HCl}, \quad 50 \mathrm{mM} \mathrm{NaCl}, 1 \mathrm{mM}$ EDTA, $0.1 \mathrm{mM}$ Tris(2- 30

carboxyethyl)phosphine hydrochloride), $\mathrm{pH} 7.0$

$20 \mathrm{mM}$ Tris- $\mathrm{HCl}, \quad 50 \mathrm{mM} \mathrm{NaCl}, 1 \mathrm{mM}$ EDTA, $0.1 \mathrm{mM}$ Tris(2- 30

carboxyethyl)phosphine hydrochloride), $\mathrm{pH} 7.0$

$50 \mathrm{mM}$ sodium acetate, $100 \mathrm{mM} \mathrm{NaCl}, 5 \mathrm{mM}$ DTT, $1 \mathrm{mM} \mathrm{NaN} 3$, and 125 mM EDTA, pH 6.6

$50 \mathrm{mM}$ Tris, $0.1 \mathrm{M} \mathrm{KCl}, 10 \%$ glycerol, $10 \mathrm{mM} \mathrm{MgCl} 2,2 \mathrm{mM}$ ATP $\gamma \mathrm{S}, 7.54$ $50 \mathrm{mM}$ Tris, $0.1 \mathrm{M} \mathrm{KCl}, 10 \%$ glycerol, $10 \mathrm{mM} \mathrm{MgCl} 2,2 \mathrm{mM}$ ATP $\gamma \mathrm{S}, 7.510$ $50 \mathrm{mM}$ Tris, $0.1 \mathrm{M} \mathrm{KCl}, 10 \%$ glycerol, $10 \mathrm{mM} \mathrm{MgCl2}, 2 \mathrm{mM}$ ATP $\gamma \mathrm{S}, 7.5$ $50 \mathrm{mM}$ Tris, $0.1 \mathrm{M} \mathrm{KCl}, 10 \%$ glycerol, $10 \mathrm{mM} \mathrm{MgCl} 2,2 \mathrm{mM} \mathrm{ATP} \gamma \mathrm{S}, 7.520$ $50 \mathrm{mM}$ Tris, $0.1 \mathrm{M} \mathrm{KCl}, 10 \%$ glycerol, $10 \mathrm{mM} \mathrm{MgCl} 2,2 \mathrm{mM} \mathrm{ATP} \gamma \mathrm{S}, 7.528$ $20 \mathrm{mM}$ MOPS, $0.1 \mathrm{M} \mathrm{KCl}, 10 \%$ glycerol, $10 \mathrm{mM} \mathrm{MgCl} 2,2 \mathrm{mM}$ ATP $\gamma \mathrm{S}, 7.510$ $20 \mathrm{mM}$ MOPS, $0.1 \mathrm{M} \mathrm{KCl}, 10 \%$ glycerol, $10 \mathrm{mM} \mathrm{MgCl} 2,2 \mathrm{mM}$ ATP $\gamma \mathrm{S}, 7.528$ $50 \mathrm{mM}$ Tris, $0.1 \mathrm{M} \mathrm{KCl}, 10 \%$ glycerol, $10 \mathrm{mM} \mathrm{MgCl} 2,2 \mathrm{mM}$ ATP $\gamma \mathrm{S}, 7.5 \quad 12$ $50 \mathrm{mMT}$ Tr, $0.1 \mathrm{MKCl}, 10 \%$ glycerol, $10 \mathrm{mM} \mathrm{MgCl} 2,2 \mathrm{mM} \mathrm{ATP} \gamma \mathrm{S}, 7.5$ $50 \mathrm{mM}$ Tris, $0.1 \mathrm{M} \mathrm{KCl}, 10 \%$ glycerol, $10 \mathrm{mM} \mathrm{MgCl} 2,2 \mathrm{mM} \mathrm{ATP} \gamma \mathrm{S}, 7.56$ $50 \mathrm{mM}$ Tris, $0.1 \mathrm{M} \mathrm{KCl}, 10 \%$ glycerol, $10 \mathrm{mM} \mathrm{MgCl} 2,2 \mathrm{mM}$ ATP $\gamma \mathrm{S}, 7.5$ $50 \mathrm{mM}$ Tris, $0.1 \mathrm{M} \mathrm{KCl}, 10 \%$ glycerol, $10 \mathrm{mM} \mathrm{MgCl} 2,2 \mathrm{mM}$ ATP $\gamma \mathrm{S}, 7.5 \quad 18$ $50 \mathrm{mM}$ Hepes, $2 \mathrm{mM} \mathrm{CaCl} 2$, $\mathrm{pH} 7.5$

$50 \mathrm{mM}$ Hepes, $2 \mathrm{mM} \mathrm{CaCl} 2$, $\mathrm{pH} 7.5$

$50 \mathrm{mM}$ Hepes, $2 \mathrm{mM} \mathrm{CaCl} 2$, $\mathrm{pH} 7.5$

$50 \mathrm{mM}$ Hepes, $2 \mathrm{mM} \mathrm{CaCl} 2$, $\mathrm{pH} 7.5$

$50 \mathrm{mM}$ Hepes, $2 \mathrm{mM} \mathrm{CaCl} 2$, $\mathrm{pH} 7.5$

$20 \mathrm{mM}$ MES, $10 \mathrm{mM} \mathrm{NaCl}, \mathrm{pH} 6.0$

$20 \mathrm{mM}$ MES, $10 \mathrm{mM} \mathrm{NaCl}, \mathrm{pH} 6.0$

$20 \mathrm{mM}$ MES, $10 \mathrm{mM} \mathrm{NaCl}, \mathrm{pH} 6.0$

$20 \mathrm{mM}$ MES, $10 \mathrm{mM} \mathrm{NaCl}$, pH 6.0

$20 \mathrm{mM}$ MES, $10 \mathrm{mM} \mathrm{NaCl}, \mathrm{pH} 6.0$

$20 \mathrm{mM}$ MES, $10 \mathrm{mM} \mathrm{NaCl}$, pH 6.0

$20 \mathrm{mM}$ MES, $10 \mathrm{mM} \mathrm{NaCl}$, pH 6.0

$20 \mathrm{mM}$ MES, $10 \mathrm{mM} \mathrm{NaCl}, \mathrm{pH} 6.0$

$10 \mathrm{mM}$ phosphate buffer, $\mathrm{pH} 7.5$

$10 \mathrm{mM}$ phosphate buffer, $\mathrm{pH} 7.5$

$10 \mathrm{mM}$ HEPES, $150 \mathrm{mM} \mathrm{NaCl}, 2 \mathrm{mM} \mathrm{MgCl} 2,10 \mathrm{mM}$ EGTA, and $0.005 \%(\mathrm{v} / \mathrm{v})$ Tween $20, \mathrm{pH} 7.4$

$10 \mathrm{mM}$ HEPES, $150 \mathrm{mM} \mathrm{NaCl}, 2 \mathrm{mM} \mathrm{MgCl} 2,10 \mathrm{mM}$ EGTA, and $0.005 \%(\mathrm{v} / \mathrm{v})$ Tween $20, \mathrm{pH} 7.4$

$10 \mathrm{mM}$ HEPES, $150 \mathrm{mM} \mathrm{NaCl}, 2 \mathrm{mM} \mathrm{MgCl} 2,10 \mathrm{mM}$ EGTA, and $0.005 \%(\mathrm{v} / \mathrm{v})$ Tween $20, \mathrm{pH} 7.4$

$10 \mathrm{mM}$ HEPES, $150 \mathrm{mM} \mathrm{NaCl}, 2 \mathrm{mM} \mathrm{MgCl} 2,10 \mathrm{mM}$ EGTA, and $0.005 \%(\mathrm{v} / \mathrm{v})$ Tween 20, pH 7.4

$10 \mathrm{mM}$ HEPES, $150 \mathrm{mM} \mathrm{NaCl}, 2 \mathrm{mM} \mathrm{MgCl} 2,10 \mathrm{mM}$ EGTA, and $0.005 \%(\mathrm{v} / \mathrm{v})$ Tween $20, \mathrm{pH} 7.4$

$20 \mathrm{mM}$ phosphate buffer, $\mathrm{pH} 7.0$ $\begin{array}{llll}-32.2 & -34.3 & -2.1 & 95\end{array}$

$\begin{array}{llll}-32.2 & -19.5 & 12.7 & 96\end{array}$

$\begin{array}{llll}-26.4 & 83.7 & 110.0 & 97\end{array}$

$\begin{array}{llll}-33.1 & 75.3 & 108.4 & 97\end{array}$

$\begin{array}{llll}-34.7 & 25.1 & 59.8 & 97\end{array}$

$\begin{array}{llll}-38.1 & -16.7 & 21.3 & 97\end{array}$

$\begin{array}{llll}-38.9 & -20.9 & 18.0 & 97\end{array}$

$\begin{array}{llll}-38.9 & 12.6 & 51.5 & 97\end{array}$

$\begin{array}{llll}-83.7 & -2.9 & 80.8 & 97\end{array}$

$\begin{array}{llll}-38.5 & 16.7 & 55.2 & 97\end{array}$

$\begin{array}{llll}-40.6 & -8.4 & 32.2 & 97\end{array}$

$\begin{array}{llll}-38.1 & 184.1 & 222.2 & 97\end{array}$

$\begin{array}{llll}-38.5 & 133.9 & 172.4 & 97\end{array}$

$\begin{array}{llll}-38.9 & 25.1 & 64.0 & 97\end{array}$

$\begin{array}{llll}-43.3 & -55.3 & -11.8 & 98\end{array}$

$\begin{array}{llll}-36.3 & -32.4 & 3.9 & 98\end{array}$

$\begin{array}{llll}-42.8 & -56.3 & -13.5 & 98\end{array}$

$\begin{array}{llll}-37.8 & -54.7 & -17.7 & 98\end{array}$

$\begin{array}{llll}-41.9 & -58.1 & -16.2 & 98\end{array}$

$\begin{array}{llll}-27.6 & -7.7 & 19.8 & 99\end{array}$

$\begin{array}{llll}-29.4 & -14.4 & 15.0 & 99\end{array}$

$\begin{array}{llll}-30.3 & -16.2 & 14.1 & 99\end{array}$

$\begin{array}{llll}-31.0 & -7.8 & 23.1 & 99\end{array}$

$\begin{array}{llll}-31.0 & -7.7 & 23.2 & 99\end{array}$

$\begin{array}{llll}-29.7 & -14.6 & 15.1 & 99\end{array}$

$\begin{array}{llll}-27.5 & -11.1 & 16.4 & 99\end{array}$

$\begin{array}{llll}-27.6 & -13.9 & 13.7 & 99\end{array}$

$\begin{array}{llll}-17.8 & -4.7 & 13.1 & 100\end{array}$

$\begin{array}{llll}-7.6 & 3.8 & 11.4 & 100\end{array}$

$\begin{array}{llll}-7.6 & 3.8 & 11.4 & 100 \\ -34.8 & 25.9 & 60.7 & 101\end{array}$

$\begin{array}{lllll} & -37.9 & 31.2 & 69.1 & 101\end{array}$

$\begin{array}{lllll}25 & -41.3 & 11.9 & 53.2 & 101\end{array}$

$\begin{array}{lllll}25 & -33.0 & 33.3 & 66.3 & 101\end{array}$

$\begin{array}{lllll}25 & -33.7 & 27.0 & 60.8 & 10\end{array}$

$\begin{array}{llll}25 & -25.8 & -63.2 & -37.6\end{array}$ 
Ab1-SH3/ APR-RP1 peptide

Native IL-8/ CXCR1N

Native IL-8 monomer/ CXCR1N

Sem-5 C-SH3/ SosY I

Sem-5 C-SH3/ SosY I

Sem-5 C-SH3/ SosY I

Sem-5 C-SH3/ SosY III

Sem-5 C-SH3/ SosY III

Sem-5 C-SH3/ SosY III

Sem-5 C-SH3/ SosY III

Sem-5 C-SH3/ SosY III

Sem-5 C-SH3/ SosY II

Sem-5 C-SH3/ SosY II

Sem-5 C-SH3/ SosY II

Sem-5 C-SH3/ SosY II

Sem-5 C-SH3/ SosY III

Sem-5 C-SH3/ SosY III

Sem-5 C-SH3/ SosY III

Wild type FAT/ LD2 peptide (Helix 1,4 site)

E949A/K956A/R963A/ LD2 peptide (Helix 1,4 site)

Pyk2/ LD2 peptide (Helix 1,4 site)

Wild type FAT/ LD2 peptide (Helix 2,3 site)

1937A/ LD2 peptide (Helix 2,3 site)

Pyk2/ LD2 peptide (Helix 2,3 site)

C3/ V4W/H9A peptide

$\mathrm{C} 3 /$ V4W/H9A peptide

C3/ V4W/H9A peptide

C3/ V4W/H9A peptide

$\mathrm{C} 3 /$ V4W/H9A peptide

C3/ V4W/H9A peptide

$\mathrm{C} 3 /$ V4W/H9A peptide

C3/ V4W/H9A peptide

$\mathrm{C} 3 /$ V4W/H9A peptide

C3/ V4W/H9A peptide

C3/ V4W/H9A peptide

$\mathrm{C} 3 /$ V4W/H9A peptide

C3/ V4H9 peptide

C3/ V4H9 peptide

C3/ V4H9 peptide

C3/ V4H9 peptide

$\mathrm{C} 3 /$ V4H9 peptide

$\mathrm{C} 3 /$ V4H9 peptide

C3/ V4H9 peptide

$\mathrm{C} 3 /$ V4H9 peptide
$20 \mathrm{mM}$ phosphate buffer, $\mathrm{pH} 7.0$

$50 \mathrm{mM} \mathrm{NaCl}, 50 \mathrm{mM}$ HEPES, $\mathrm{pH} 8.0$

$50 \mathrm{mM} \mathrm{NaCl}, 50 \mathrm{mM}$ HEPES, $\mathrm{pH} 8.0$

$20 \mathrm{mM}$ Tris and $200 \mathrm{mM} \mathrm{NaCl}, \mathrm{pH} 9.0$

$20 \mathrm{mM}$ Tris and $200 \mathrm{mM} \mathrm{NaCl}, \mathrm{pH} 8.5$

$20 \mathrm{mM}$ Tris and $200 \mathrm{mM} \mathrm{NaCl}, \mathrm{pH} 8.0$

$20 \mathrm{mM}$ Tris and $200 \mathrm{mM} \mathrm{NaCl}, \mathrm{pH} 7.5$

$20 \mathrm{mM}$ Tris and $200 \mathrm{mM} \mathrm{NaCl}, \mathrm{pH} 7.5$

$20 \mathrm{mM}$ Tris and $200 \mathrm{mM} \mathrm{NaCl}, \mathrm{pH} 7.5$

$20 \mathrm{mM}$ Tris and $200 \mathrm{mM} \mathrm{NaCl}$, pH 7.5

$20 \mathrm{mM}$ Tris and $200 \mathrm{mM} \mathrm{NaCl}, \mathrm{pH} 7.5$

$20 \mathrm{mM}$ Tris and $200 \mathrm{mM} \mathrm{NaCl}, \mathrm{pH} 7.5$

$20 \mathrm{mM}$ imidazole and $200 \mathrm{mM} \mathrm{NaCl}, \mathrm{pH} 7.5$

$20 \mathrm{mM}$ Hepes and $200 \mathrm{mM} \mathrm{NaCl}, \mathrm{pH} 7.5$

$20 \mathrm{mM}$ phosphate and $200 \mathrm{mM} \mathrm{NaCl}, \mathrm{pH} 7.5$

$20 \mathrm{mM}$ imidazole and $200 \mathrm{mM} \mathrm{NaCl}, \mathrm{pH} 7.0$

$20 \mathrm{mM}$ imidazole and $200 \mathrm{mM} \mathrm{NaCl}, \mathrm{pH} 6.5$

$50 \mathrm{mM}$ sodium acetate, $100 \mathrm{mM} \mathrm{NaCl}$ and $10 \mathrm{mM} \mathrm{CaCl}_{2} \cdot \mathrm{pH} 4.8$

$50 \mathrm{mM}$ HEPES, $100 \mathrm{mM} \mathrm{NaCl}$, and $2 \mathrm{mM} \mathrm{NaN}_{3}$ at $\mathrm{pH} 7.0$

$50 \mathrm{mM}$ HEPES, $100 \mathrm{mM} \mathrm{NaCl}$, and $2 \mathrm{mM} \mathrm{NaN}_{3}$ at $\mathrm{pH} 7.0$

$50 \mathrm{mM}$ HEPES, $100 \mathrm{mM} \mathrm{NaCl}$, and $2 \mathrm{mM} \mathrm{NaN}_{3}$ at $\mathrm{pH} 7.0$

$50 \mathrm{mM}$ HEPES, $100 \mathrm{mM} \mathrm{NaCl}$, and $2 \mathrm{mM} \mathrm{NaN}_{3}$ at $\mathrm{pH} 7.0$

$50 \mathrm{mM}$ HEPES, $100 \mathrm{mM} \mathrm{NaCl}$, and $2 \mathrm{mM} \mathrm{NaN}_{3}$ at $\mathrm{pH} 7.0$

$50 \mathrm{mM}$ HEPES, $100 \mathrm{mM} \mathrm{NaCl}$, and $2 \mathrm{mM} \mathrm{NaN}_{3}$ at pH 7.0

PBS, pH 7.4

PBS, pH 7.4

PBS, pH 7.4

PBS, pH 7.4

Tris, $\mathrm{pH} 7.4$

MOPS, pH 7.4

PBS, pH 6.7

Tris, $\mathrm{pH} 6.7$

MOPS, pH 6.7

$\mathrm{PB}, \mathrm{pH} 7.4$

PBS, 0.5 M glycerol, pH 7.4

PBS, $1 \mathrm{M}$ glycerol, $\mathrm{pH} 7.4$

PBS, pH 7.4

PBS, pH 7.4

PBS, $\mathrm{pH} 7.4$

PBS, pH 7.4

Tris, $\mathrm{pH} 7.4$

MOPS, pH 7.4

PBS, pH 6.7

Tris, pH 6.7

\begin{tabular}{lllll}
25 & -23.0 & -61.5 & -38.5 & 102 \\
25 & -30.5 & -29.3 & 1.3 & 103 \\
25 & -29.7 & -43.9 & -14.2 & 103 \\
25.1 & -25.5 & -39.3 & -13.80 & 104 \\
25.1 & -25.1 & -36.0 & -10.9 & 104 \\
25.1 & -25.1 & -38.1 & -13.0 & 104 \\
15.2 & -25.1 & -27.6 & -2.5 & 104 \\
20.2 & -25.1 & -31.4 & -6.3 & 104 \\
35.2 & -25.1 & -34.7 & -9.6 & 104 \\
25.1 & -25.1 & -37.7 & -12.6 & 104 \\
25.1 & -24.7 & -41.8 & -17.2 & 104 \\
25.1 & -25.1 & -38.1 & -13.0 & 104 \\
25.1 & -25.1 & -33.9 & -8.8 & 104 \\
25.1 & -25.1 & -31.8 & -6.7 & 104 \\
25.1 & -25.1 & -33.5 & -8.4 & 104 \\
25.1 & -24.7 & -35.1 & -10.5 & 104 \\
25.1 & -24.3 & -38.9 & -14.6 & 104 \\
25.1 & -20.1 & -28.0 & -7.9 & 104 \\
26 & -28.9 & -30.1 & -1.3 & 105 \\
26 & -30.7 & -23.0 & 7.5 & 105 \\
& & & & \\
26 & -24.9 & -41.8 & -16.7 & 105 \\
26 & -28.3 & 4.6 & 32.6 & 105 \\
26 & -27.9 & 1.3 & 28.9 & 105 \\
26 & -26.8 & 1.3 & 28.0 & 105 \\
15 & -39.5 & -61.1 & -21.8 & 106 \\
20 & -39.9 & -70.7 & -31.0 & 106 \\
25 & -39.3 & -75.9 & -36.8 & 106 \\
37 & -37.9 & -99.6 & -61.9 & 106 \\
25 & -40.3 & -61.5 & -21.5 & 106 \\
25 & -39.6 & -66.2 & -26.8 & 106 \\
25 & -40.4 & -75.0 & -34.7 & 106 \\
25 & -40.8 & -54.0 & -13.4 & 106 \\
25 & -40.4 & -65.3 & -25.0 & 106 \\
25 & -39.9 & -66.5 & -26.8 & 106 \\
25 & -39.7 & -126.8 & -91.6 & 106 \\
25 & -38.7 & -92.5 & -54.0 & 106 \\
15 & -34.6 & -39.7 & -5.3 & 106 \\
20 & -32.6 & -46.5 & -14.1 & 106 \\
25 & -33.8 & -50.7 & -17.1 & 106 \\
37 & -31.2 & -58.5 & -27.4 & 106 \\
25 & -33.8 & -66.9 & -33.4 & 106 \\
25 & -31.6 & -62.8 & -31.4 & 106 \\
25 & -34.6 & -53.7 & -19.2 & 106 \\
25 & -32.9 & -57.3 & -24.6 & 106 \\
\hline & & & &
\end{tabular}


C3/ V4H9 peptide

C3/ V4H9 peptide

C3/ V4H9 peptide

C3/ V4H9 peptide

PDZ3 fromPSD-95/ peptide ligand 2

PDZ3 fromPSD-95/ peptide ligand 4

PDZ3 fromPSD-95/ peptide ligand 5

PDZ3 fromPSD-95/ peptide ligand 6

PDZ3 fromPSD-95/ peptide ligand 7

PDZ3 fromPSD-95/ peptide ligand 8

PDZ3 fromPSD-95/ peptide ligand 9

PDZ3 fromPSD-95/ peptide ligand $\mathbf{1 0}$

PDZ3 fromPSD-95/ peptide ligand 12

PDZ3 fromPSD-95/ peptide ligand 13

PDZ3 fromPSD-95/ peptide ligand 14

PDZ3 fromPSD-95/ peptide ligand 15

Abl-SH3 domain/ p41

Abl-SH3 domain/ p41

Abl-SH3 domain/ p40

Abl-SH3 domain/ p7

Abl-SH3 domain/ 0

Abl-SH3 domain/ 3BP1

PDZ3 from PSD-95/KKETEX (X=Ala, Me)

PDZ3 from PSD-95/KKETEX (X=Aib, Me,Me)

PDZ3 from PSD-95/ KKETE $X$ (X=Abu, Et)

PDZ3 from PSD-95/KKETE $X$ (X=Val, i-Pr)

PDZ3 from PSD-95/KKETEX (X=Ape, $\mathrm{nPr})$

PDZ3 from PSD-95/KKETE $X$ ( $\mathrm{X}=\mathrm{Tle}, \mathrm{t}-\mathrm{Bu})$

PDZ3 from PSD-95/KKETE $X$ (X=Ile, s-Bu)

PDZ3 from PSD-95/ KKETEX (X=Leu, $\mathrm{i}-\mathrm{Bu})$

Disabled-1 PTB native/ ApoER2 Peptide

Disabled-1 PTB mutant H81Q/ ApoER2 Peptide

Disabled-1 PTB mutant K45A/ ApoER2 Peptide

Disabled-1 PTB mutant K45Q/ ApoER2 Peptide

Disabled-1 PTB mutant K45E/ ApoER2 Peptide

Disabled-1 PTB mutant K82A/ ApoER2 Peptide

Disabled-1 PTB mutant K82Q/ ApoER2 Peptide

Disabled-1 PTB mutant K45A/K82A/ ApoER2

Peptide

Disabled-1 PTB mutant K45Q/K82Q/ ApoER2

Peptide

Disabled-1 PTB mutant K45E/K82Q/ ApoER2
PDZ3 fromPSD-95/ peptide ligand $\mathbf{1 1}$

PDZ3 from PSD-95/KKETEX (X=Ahx, n-Bu)
MOPS, pH 6.7

$\mathrm{PB}, \mathrm{pH} 7.4$

PBS, 0.5 M glycerol, pH 7.4

PBS, $1 \mathrm{M}$ glycerol, $\mathrm{pH} 7.4$

20 mM MES, pH 6.0

20 mM MES, pH 6.0

$20 \mathrm{mM}$ MES, pH 6.0

$20 \mathrm{mM}$ MES, pH 6.0

20 mM MES, pH 6.0

20 mM MES, pH 6.0

20 mM MES, pH 6.0

$20 \mathrm{mM}$ MES, pH 6.0

$20 \mathrm{mM}$ MES, pH 6.0

20 mM MES, pH 6.0

$20 \mathrm{mM}$ MES, $\mathrm{pH} 6.0$

$20 \mathrm{mM}$ MES, $\mathrm{pH} 6.0$

$20 \mathrm{mM}$ MES, pH 6.0

$20 \mathrm{mM}$ sodium phosphate, $\mathrm{pH} 7.0$

$20 \mathrm{mM}$ sodium phosphate, $\mathrm{pH} 7.0$

$20 \mathrm{mM}$ sodium phosphate, $\mathrm{pH} 7.0$

$20 \mathrm{mM}$ sodium phosphate, $\mathrm{pH} 7.0$

$20 \mathrm{mM}$ sodium phosphate, $\mathrm{pH} 7.0$

$20 \mathrm{mM}$ sodium phosphate, $\mathrm{pH} 7.0$

$20 \mathrm{mM}$ MES, $10 \mathrm{mM} \mathrm{NaCl}$, pH 6.0

$20 \mathrm{mM}$ MES, $10 \mathrm{mM} \mathrm{NaCl}, \mathrm{pH} 6.0$

$20 \mathrm{mM}$ MES, $10 \mathrm{mM} \mathrm{NaCl}, \mathrm{pH} 6.0$

$20 \mathrm{mM}$ MES, $10 \mathrm{mM} \mathrm{NaCl}$, pH 6.0

$20 \mathrm{mM}$ MES, $10 \mathrm{mM} \mathrm{NaCl}$, pH 6.0

$20 \mathrm{mM}$ MES, $10 \mathrm{mM} \mathrm{NaCl}, \mathrm{pH} 6.0$

$20 \mathrm{mM}$ MES, $10 \mathrm{mM} \mathrm{NaCl}, \mathrm{pH} 6.0$

$20 \mathrm{mM}$ MES, $10 \mathrm{mM} \mathrm{NaCl}$, pH 6.0

$20 \mathrm{mM}$ MES, $10 \mathrm{mM} \mathrm{NaCl}, \mathrm{pH} 6.0$

$20 \mathrm{mM}$ PIPES buffer, $150 \mathrm{mM} \mathrm{NaCl}, 0.2 \mathrm{mM}$ DTT, pH 7.0

$20 \mathrm{mM}$ PIPES buffer, $150 \mathrm{mM} \mathrm{NaCl}, 0.2 \mathrm{mM}$ DTT, pH 7.0

$20 \mathrm{mM}$ PIPES buffer, $150 \mathrm{mM} \mathrm{NaCl}, 0.2 \mathrm{mM}$ DTT, pH 7.0

$20 \mathrm{mM}$ PIPES buffer, $150 \mathrm{mM} \mathrm{NaCl}, 0.2 \mathrm{mM}$ DTT, pH 7.0

$20 \mathrm{mM}$ PIPES buffer, $150 \mathrm{mM} \mathrm{NaCl}, 0.2 \mathrm{mM}$ DTT, $\mathrm{pH} 7.0$

$20 \mathrm{mM}$ PIPES buffer, $150 \mathrm{mM} \mathrm{NaCl}, 0.2 \mathrm{mM}$ DTT, pH 7.0

$20 \mathrm{mM}$ PIPES buffer, $150 \mathrm{mM} \mathrm{NaCl}, 0.2 \mathrm{mM}$ DTT, pH 7.0

20 mM PIPES buffer, 150 mM NaCl, 0.2 mM DTT, pH 7.0

20 mM PIPES buffer, 150 mM NaCl, 0.2 mM DTT, pH 7.0

20 mM PIPES buffer, 150 mM NaCl, 0.2 mM DTT, pH 7.0

$\begin{array}{llll}-33.8 & -49.7 & -16.1 & 106 \\ -34.2 & -52.6 & -18.6 & 106 \\ -33.5 & -46.6 & -13.2 & 106 \\ -32.8 & -76.8 & -44.2 & 106 \\ -24.0 & -8.6 & 15.4 & 107 \\ -23.9 & -5.1 & 18.7 & 107 \\ -27.0 & -10.3 & 16.7 & 107 \\ -25.8 & -12.3 & 13.5 & 107 \\ -25.4 & -10.3 & 15.2 & 107 \\ -30.5 & -9.6 & 21.0 & 107 \\ -28.7 & -11.5 & 17.3 & 107 \\ -26.8 & -5.9 & 21.0 & 107 \\ -29.7 & -14.2 & 15.6 & 107 \\ -30.0 & -20.0 & 10.0 & 107 \\ -24.9 & -5.8 & 19.1 & 107 \\ -24.4 & -6.8 & 17.7 & 107 \\ -30.2 & -12.9 & 17.4 & 107 \\ -32.2 & -91.6 & -59.4 & 108 \\ -32.2 & -88.3 & -56.1 & 108 \\ -31.8 & -76.6 & -44.8 & 108 \\ -28.9 & -73.2 & -44.4 & 108 \\ -28.9 & -71.1 & -42.3 & 108 \\ -25.5 & -69.9 & -44.4 & 108 \\ -23.1 & -19.1 & 4.0 & 109 \\ -22.5 & -4.3 & 18.2 & 109 \\ -30.6 & -31.8 & -1.3 & 109 \\ -32.6 & -26.1 & 6.6 & 109 \\ -34.2 & -31.0 & 3.2 & 109 \\ -31.0 & -18.7 & 12.3 & 109 \\ -29.2 & -18.0 & 11.2 & 109 \\ -29.2 & -17.2 & 11.9 & 109 \\ -29.4 & -26.9 & 2.6 & 109 \\ -32.2 & -40.2 & -7.9 & 74 \\ -33.1 & -45.2 & -12.1 & 74 \\ -32.2 & -42.3 & -10.0 & 74 \\ -31.6 & -33.9 & -2.5 & 74 \\ -32.3 & -44.4 & -12.1 & 74 \\ -33.4 & -46.0 & -12.6 & 74 \\ -32.9 & -60.7 & -27.6 & 74 \\ -31.5 & -36.8 & -5.4 & 74 \\ & & & \\ -31.8 & -38.9 & -7.1 & 74 \\ & & & \\ -32.4 & -42.7 & -10.5 & 74 \\ & & & \end{array}$

Peptide 
Cob B/ H4-11 peptide

Cob B/p53-11 peptide

Cob B/ Acs-11 peptide

Cob B/ Acs-15 peptide

SjGST-Y7F/ GSH

SjGST-Y7F/ GSH

SjGST-Y7F/ GSH

SjGST-Y7F/ GSH

WT Human GSH Transferase/ GSH

Y49F mutant Human GSH Transferase/ GSH

WT Human GSH Transferase/ S-hexyl-GSH

Y49F mut. Human GSH Trf./ S-hexyl-GSH

SurA/ WEYIPNV peptide

SurA/ WEYIPNV peptide

SurA/ WEYIPNV peptide

SurA/ WEYIPNV peptide

$\operatorname{SurA}(\triangle \mathrm{P} 2) /$ WEYIPNV peptide

$\operatorname{SurA}(\Delta \mathrm{P} 2) /$ WEYIPNV peptide

SurA $(\triangle \mathrm{P} 2) /$ WEYIPNV peptide

$\operatorname{SurA}(\triangle \mathrm{P} 2) /$ WEYIPNV peptide

Fab/e-pep

CB4-1/ e-pep

Fab/e-pep

CB4-1/ e-pep

CB4-1/ e-pep

Fab/e-pep

CB4-1/ e-pep

Fab/h-pep

CB4-1/ h-pep

Fab/h-pep

CB4-1/ h-pep

CB4-1/ h-pep

Fab/h-pep

CB4-1/ h-pep

Fab/u-pep

CB4-1/ u-pep

Fab/u-pep

CB4-1/ u-pep

CB4-1/ u-pep

$\mathrm{Fab} / \mathrm{u}-\mathrm{pep}$

CB4-1/ u-pep

CB4-1/ d-pep

CB4-1/ GA-pep

CB4-1/ GA-pep

CB4-1/ AT-pep
$20 \mathrm{mM}$ Hepes, $100 \mathrm{mM} \mathrm{NaCl}, 10 \mathrm{mM}$ DTT, pH 7.5

$20 \mathrm{mM}$ Hepes, $100 \mathrm{mM} \mathrm{NaCl}, 10 \mathrm{mM}$ DTT, pH 7.5

$20 \mathrm{mM}$ Hepes, $100 \mathrm{mM} \mathrm{NaCl}, 10 \mathrm{mM}$ DTT, pH 7.5

$20 \mathrm{mM}$ Hepes, $100 \mathrm{mM} \mathrm{NaCl}, 10 \mathrm{mM}$ DTT, pH 7.5

$20 \mathrm{mM}$ phosphate, $2 \mathrm{mM}$ DTT, 1mM EDTA, $\mathrm{pH} 6.5$

$20 \mathrm{mM}$ phosphate, $2 \mathrm{mM}$ DTT, $1 \mathrm{mM}$ EDTA, $\mathrm{pH} 6.5$

$20 \mathrm{mM}$ phosphate, 2mM DTT, 1mM EDTA, pH 6.5

$20 \mathrm{mM}$ phosphate, $2 \mathrm{mM}$ DTT, $1 \mathrm{mM}$ EDTA, $\mathrm{pH} 6.5$

$5 \mathrm{mM} \mathrm{NaCl}, 0.1 \mathrm{mM}$ EDTA, $1 \mathrm{mM}$ DTT, $50 \mathrm{mM}$ Na phosphate, $\mathrm{pH} 6.5$

$5 \mathrm{mM} \mathrm{NaCl}, 0.1 \mathrm{mM}$ EDTA, $1 \mathrm{mM}$ DTT, $50 \mathrm{mM}$ Na phosphate, pH 6.5

$5 \mathrm{mM} \mathrm{NaCl}, 0.1 \mathrm{mM}$ EDTA, $1 \mathrm{mM}$ DTT, $50 \mathrm{mM}$ Na phosphate, $\mathrm{pH} 6.5$

$5 \mathrm{mM} \mathrm{NaCl}, 0.1 \mathrm{mM}$ EDTA, $1 \mathrm{mM}$ DTT, $50 \mathrm{mM}$ Na phosphate, $\mathrm{pH} 6.5$

$150 \mathrm{mM} \mathrm{NaCl}, 20 \mathrm{mM} \mathrm{NaH}_{2} \mathrm{PO}_{4}, \mathrm{pH} 7.3$

$150 \mathrm{mM} \mathrm{NaCl}, 20 \mathrm{mM} \mathrm{NaH}_{2} \mathrm{PO}_{4}, \mathrm{pH} 7.3$

$150 \mathrm{mM} \mathrm{NaCl}, 20 \mathrm{mM} \mathrm{NaH}_{2} \mathrm{PO}_{4}, \mathrm{pH} 7.3$

$150 \mathrm{mM} \mathrm{NaCl}, 20 \mathrm{mM} \mathrm{NaH}_{2} \mathrm{PO}_{4}, \mathrm{pH} 7.3$

$150 \mathrm{mM} \mathrm{NaCl}, 20 \mathrm{mM} \mathrm{NaH}_{2} \mathrm{PO}_{4}$, pH 7.3

$150 \mathrm{mM} \mathrm{NaCl}, 20 \mathrm{mM} \mathrm{NaH}_{2} \mathrm{PO}_{4}, \mathrm{pH} 7.3$

$150 \mathrm{mM} \mathrm{NaCl}, 20 \mathrm{mM} \mathrm{NaH}_{2} \mathrm{PO}_{4}, \mathrm{pH} 7.3$

$150 \mathrm{mM} \mathrm{NaCl}, 20 \mathrm{mM} \mathrm{NaH}_{2} \mathrm{PO}_{4}$, pH 7.3

$50 \mathrm{mM}$ sodium phosphate, $0.15 \mathrm{M} \mathrm{NaCl}, \mathrm{pH} 7.2$

$50 \mathrm{mM}$ sodium phosphate, $0.15 \mathrm{M} \mathrm{NaCl}, \mathrm{pH} 7.2$

$50 \mathrm{mM}$ sodium phosphate, $0.15 \mathrm{M} \mathrm{NaCl}, \mathrm{pH} 7.2$

$50 \mathrm{mM}$ sodium phosphate, $0.15 \mathrm{M} \mathrm{NaCl}, \mathrm{pH} 7.2$

$50 \mathrm{mM}$ MOPS, $0.15 \mathrm{M} \mathrm{NaCl}, \mathrm{pH} 7.2$

$50 \mathrm{mM}$ sodium phosphate, $0.15 \mathrm{M} \mathrm{NaCl}, \mathrm{pH} 7.2$

$50 \mathrm{mM}$ sodium phosphate, $0.15 \mathrm{M} \mathrm{NaCl}$, pH 7.2

$50 \mathrm{mM}$ sodium phosphate, $0.15 \mathrm{M} \mathrm{NaCl}, \mathrm{pH} 7.2$

$50 \mathrm{mM}$ sodium phosphate, $0.15 \mathrm{M} \mathrm{NaCl}, \mathrm{pH} 7.2$

$50 \mathrm{mM}$ sodium phosphate, $0.15 \mathrm{M} \mathrm{NaCl}, \mathrm{pH} 7.2$

$50 \mathrm{mM}$ sodium phosphate, $0.15 \mathrm{M} \mathrm{NaCl}, \mathrm{pH} 7.2$

$50 \mathrm{mM}$ MOPS, $0.15 \mathrm{M} \mathrm{NaCl}$, pH 7.2

$50 \mathrm{mM}$ sodium phosphate, $0.15 \mathrm{M} \mathrm{NaCl}, \mathrm{pH} 7.2$

$50 \mathrm{mM}$ sodium phosphate, $0.15 \mathrm{M} \mathrm{NaCl}, \mathrm{pH} 7.2$

$50 \mathrm{mM}$ sodium phosphate, $0.15 \mathrm{M} \mathrm{NaCl}$, pH 7.2

$50 \mathrm{mM}$ sodium phosphate, $0.15 \mathrm{M} \mathrm{NaCl}, \mathrm{pH} 7.2$

$50 \mathrm{mM}$ sodium phosphate, $0.15 \mathrm{M} \mathrm{NaCl}, \mathrm{pH} 7.2$

$50 \mathrm{mM}$ sodium phosphate, $0.15 \mathrm{M} \mathrm{NaCl}, \mathrm{pH} 7.2$

$50 \mathrm{mM}$ MOPS, $0.15 \mathrm{M} \mathrm{NaCl}$, pH 7.2

$50 \mathrm{mM}$ sodium phosphate, $0.15 \mathrm{M} \mathrm{NaCl}, \mathrm{pH} 7.2$

$50 \mathrm{mM}$ sodium phosphate, $0.15 \mathrm{M} \mathrm{NaCl}, \mathrm{pH} 7.2$

$50 \mathrm{mM}$ sodium phosphate, $0.15 \mathrm{M} \mathrm{NaCl}, \mathrm{pH} 7.2$

$50 \mathrm{mM}$ sodium phosphate, $\mathrm{pH} 7.2$

$50 \mathrm{mM}$ sodium phosphate, $0.15 \mathrm{M} \mathrm{NaCl}, \mathrm{pH} 7.2$

$50 \mathrm{mM}$ sodium phosphate, $\mathrm{pH} 7.2$

\begin{tabular}{llll}
-35.1 & -38.0 & -2.9 & 110 \\
-32.0 & -16.0 & 15.5 & 110 \\
-31.6 & -8.8 & 23.2 & 110 \\
-30.0 & -7.0 & 23.1 & 110 \\
-28.0 & -17.2 & 10.8 & 111 \\
-28.1 & -22.0 & 6.1 & 111 \\
-28.2 & -28.7 & 0.5 & 111 \\
-28.1 & -34.9 & -6.8 & 111 \\
-23.1 & -46.9 & -23.6 & 112 \\
-20.4 & -54.6 & -38.4 & 112 \\
-33.6 & -67.5 & -33.6 & 112 \\
-32.0 & -71.7 & -39.5 & 112 \\
-31.7 & -83.3 & -51.6 & 113 \\
-31.1 & -81.2 & -50.1 & 113 \\
-30.8 & -77.4 & -46.6 & 113 \\
-29.5 & -67.4 & -37.9 & 113 \\
-32.4 & -87.4 & -55.0 & 113 \\
-32.3 & -84.3 & -52.0 & 113 \\
-31.4 & -81.0 & -49.6 & 113 \\
-28.9 & -83.3 & -54.5 & 113 \\
-41.4 & -46.9 & -5.4 & 114 \\
-42.3 & -45.2 & 2.9 & 114 \\
-43.1 & -65.3 & -22.2 & 114 \\
-43.5 & -65.3 & -21.8 & 114 \\
-43.5 & -64.9 & -21.3 & 114 \\
-42.3 & -74.5 & -32.2 & 114 \\
43.1 & -77.0 & -33.9 & 114 \\
-41.8 & -40.6 & 1.3 & 114 \\
-42.3 & -42.7 & -0.4 & 114 \\
-43.5 & -58.6 & -15.1 & 114 \\
-43.9 & -58.2 & -14.2 & 114 \\
-44.4 & -60.7 & -16.3 & 114 \\
-43.9 & -69.0 & -25.1 & 114 \\
43.9 & -67.8 & -23.8 & 114 \\
-39.7 & -49.0 & -9.2 & 114 \\
-40.2 & -50.2 & 10.0 & 114 \\
-40.2 & -64.9 & -24.7 & 114 \\
-41.4 & -64.0 & -22.6 & 114 \\
-40.6 & -64.9 & -24.3 & 114 \\
-38.9 & -74.5 & -35.6 & 114 \\
-39.7 & -73.2 & -33.5 & 114 \\
-32.2 & -51.5 & -19.2 & 114 \\
-40.6 & -45.2 & -4.6 & 114 \\
-41.4 & -47.7 & -6.3 & 114 \\
-38.9 & -46.4 & -7.5 & 114 \\
\hline & & & \\
\end{tabular}


CB4-1/ SE-pep

$\mathrm{Fab} / \mathrm{SE}-$ pep

$\mathrm{Ab}$ 131/angiotensin II

Endothiapepsin/pepstatin A

HK 565 peptide/PK 262 peptide

human Grb2 (SH3)/human Sos peptide

Fyn SH3 domain/P2L peptide

Lck SH2 domain/Lck phosphopeptide

p85 SH2 domain/PDGFR phosphopeptide

Src SH2 domain/pYHmT phosphopeptide

Fyn SH2 domain/pYHmT phosphopeptide

Fyn SH2 domain/pY531 phosphopeptide

SHC N-term. Domain/EGFR1148 peptide

SHC N-term. Domain/Trk490 peptide

$\mathrm{Ab} 13 \mathrm{AD} /$ peptide $\mathrm{LZ}$

$\mathrm{Ab} 13 \mathrm{AD} /$ peptide LZ(7P14P)

$\mathrm{Ab} 29 \mathrm{AB} /$ peptide LZ

Ab 29AB/peptide LZ(7P14P)

$\mathrm{Ab}$ 42PF/peptide LZ(7P14P)

calmodulinCa ${ }^{2+} /$ melittin

Calmodulin/melittin

ribonuclease S/truncated S peptide

Streptavidin/FSHPQNT peptide

Streptavidin/pStrep-tag

CheR/receptor pentapeptide

Profiling/Pro11

A/B heterodimeric coiled coil

GroEL/unfolded subtilisin BPN' mutant

Jel42 scFv/HPr

$\mathrm{Jel} 42 \mathrm{scFv} / \mathrm{HPr}$

$\mathrm{Jel} 42 \mathrm{scFv} / \mathrm{HPr}$

$\mathrm{Jel} 42 \mathrm{scFv} / \mathrm{HPr}$

$\mathrm{Jel} 42 \mathrm{scFv} / \mathrm{HPr}$

Jel42 scFv/HPr
$50 \mathrm{mM}$ sodium phosphate, $\mathrm{pH} 7.2$

$50 \mathrm{mM}$ sodium phosphate, $\mathrm{pH} 7.2$

$20 \mathrm{mM}$ buffer, $50 \mathrm{mM} \mathrm{NaCl}$, pH 7.3

$20 \mathrm{mM}$ phosphate, $\mathrm{pH} 7.0$

$30 \mathrm{mM}$ phosphate, $\mathrm{pH} 7.0$

$50 \mathrm{mM}$ potassium phosphate, $1 \mathrm{mM}$ DTT, $\mathrm{pH} 8.0$

$10 \mathrm{mM}$ phosphate, $\mathrm{pH} 6.0$

$50 \mathrm{mM}$ Mops, $100 \mathrm{nM} \mathrm{NaCl}, 1 \mathrm{mM}$ DTT, pH 6.8

$50 \mathrm{mM}$ Mops, $100 \mathrm{nM} \mathrm{NaCl}, 1 \mathrm{mM}$ DTT, pH 6.8

$50 \mathrm{mM}$ Mops, $100 \mathrm{nM} \mathrm{NaCl}, 1 \mathrm{mM}$ DTT, pH 6.8

$10 \mathrm{mM}$ potassium phosphate, $30 \mathrm{mM} \mathrm{NaCl}, 5 \mathrm{mM}$ DTT, $\mathrm{pH} 6.0$

$10 \mathrm{mM}$ potassium phosphate, $30 \mathrm{mM} \mathrm{NaCl}, 5 \mathrm{mM}$ DTT, pH 6.0

$100 \mathrm{mM}$ Hepes, $100 \mathrm{mM} \mathrm{NaCl}, 1 \mathrm{mM}$ DTT, pH 7.5

$100 \mathrm{mM}$ Hepes, $100 \mathrm{mM} \mathrm{NaCl}, 1 \mathrm{mM}$ DTT, pH 7.5

$1.46 \mathrm{mM} \mathrm{KH}_{2} \mathrm{PO}_{4}, 6.46 \mathrm{mM} \mathrm{Na}_{2} \mathrm{HPO}_{4}, 0.14 \mathrm{M} \mathrm{NaCl}, 0.27 \mathrm{mM} \mathrm{KCl}, \mathrm{pH} 7.2$

$1.46 \mathrm{mM} \mathrm{KH}_{2} \mathrm{PO}_{4} 6.46 \mathrm{mM} \mathrm{Na}_{2} \mathrm{HPO}_{4}, 0.14 \mathrm{M} \mathrm{NaCl}, 0.27 \mathrm{mM} \mathrm{KCl}, \mathrm{pH} 7.2$

$1.46 \mathrm{mM} \mathrm{KH}_{2} \mathrm{PO}_{4}, 6.46 \mathrm{mM} \mathrm{Na}_{2} \mathrm{HPO}_{4}, 0.14 \mathrm{M} \mathrm{NaCl}, 0.27 \mathrm{mM} \mathrm{KCl}, \mathrm{pH} 7.2$

$1.46 \mathrm{mM} \mathrm{KH}_{2} \mathrm{PO}_{4}, 6.46 \mathrm{mM} \mathrm{Na}_{2} \mathrm{HPO}_{4}, 0.14 \mathrm{M} \mathrm{NaCl}, 0.27 \mathrm{mM} \mathrm{KCl}, \mathrm{pH} 7.2$

$1.46 \mathrm{mM} \mathrm{KH}_{2} \mathrm{PO}_{4}, 6.46 \mathrm{mM} \mathrm{Na}_{2} \mathrm{HPO}_{4}, 0.14 \mathrm{M} \mathrm{NaCl}, 0.27 \mathrm{mM} \mathrm{KCl}, \mathrm{pH} 7.2$

$50 \mathrm{mM}$ Pipes/NaOH, $150 \mathrm{mM} \mathrm{NaCl}, 0.5 \mathrm{mM} \mathrm{CaCl} 2, \mathrm{pH} 7.0$

$50 \mathrm{mM}$ Pipes/ $\mathrm{NaOH}, 150 \mathrm{mM} \mathrm{NaCl}, \mathrm{pH} 7.0$

$50 \mathrm{mM}$ sodium acetate, $100 \mathrm{mM} \mathrm{NaCl}, \mathrm{pH} 6.0$

$50 \mathrm{mM}$ potassium phosphate, $\mathrm{pH} 7.62$

$50 \mathrm{mM}$ potassium phosphate, $\mathrm{pH} 7.62$

$20 \mathrm{mM}$ potassium phosphate, $20 \mathrm{mM} \mathrm{NaCl}, 1 \mathrm{mM}$ EDTA, $1 \mathrm{mM}$ PMSF, 28

$\mathrm{pH} 7.0$

$10 \mathrm{mM}$ Tris, $75 \mathrm{mM} \mathrm{KCl}, 3.1 \mathrm{mM} \mathrm{NaN}_{3}, \mathrm{pH} 7.5$

$10 \mathrm{mM}$ sodium phosphate, ionic strength $22 \mathrm{mM}, \mathrm{pH} 7.2$

$50 \mathrm{mM}$ Tris, $100 \mathrm{mM} \mathrm{KCl,} 1 \mathrm{mM}$ DTT, $0.1 \mathrm{mM}$ EDTA, pH 7.8

$15 \mathrm{mM}$ sodium phosphate buffer, $\mathrm{pH} 7.2$

$15 \mathrm{mM}$ sodium phosphate buffer, $\mathrm{pH} 7.2$

$15 \mathrm{mM}$ sodium phosphate buffer, $\mathrm{pH} 7.2$

$15 \mathrm{mM}$ sodium phosphate buffer, $\mathrm{pH} 7.2$

$15 \mathrm{mM}$ sodium phosphate buffer, $\mathrm{pH} 7.2$

$15 \mathrm{mM}$ sodium phosphate buffer, $\mathrm{pH} 7.2$

$\begin{array}{llll}-29.3 & -72.8 & -43.5 & 114 \\ -29.7 & -73.2 & -43.5 & 114 \\ -46.0 & -37.2 & 8.8 & 115 \\ -38.1 & -10.5 & 27.6 & 116 \\ -24.7 & 1.7 & 26.8 & 117 \\ -26.8 & -25.9 & 0.9 & 118 \\ -27.6 & -51.5 & -23.6 & 119 \\ -30.5 & -35.1 & -4.4 & 120 \\ -36.4 & -39.3 & -3.0 & 120 \\ -36.0 & -35.1 & 0.5 & 120 \\ -26.4 & -18.0 & 8.2 & 121 \\ -35.1 & -36.4 & -1.6 & 121 \\ -43.1 & -22.8 & 20.2 & 122 \\ -42.3 & 10.0 & 52.0 & 122 \\ -43.9 & -52.7 & -8.9 & 123 \\ -39.7 & -72.8 & -32.7 & 123 \\ -46.0 & -57.7 & -11.9 & 123 \\ -39.7 & -71.5 & -32.4 & 123 \\ -43.5 & -56.1 & -12.6 & 123 \\ -49.0 & 30.1 & 79.0 & 124 \\ -33.9 & 20.1 & 54.0 & 124 \\ -39.3 & -175.3 & -136.0 & 125 \\ -22.2 & -80.8 & -58.6 & 126 \\ -25.5 & -52.7 & -27.2 & 127 \\ -33.1 & -56.9 & -23.8 & 128 \\ & & & \\ -22.6 & -21.3 & 1.4 & 129 \\ -44.4 & -103.3 & -59.2 & 130 \\ -31.8 & 83.3 & 115.1 & 131 \\ -43.5 & 2.7 & 46.4 & 132 \\ -44.8 & -6.7 & 38.1 & 132 \\ -45.6 & -14.2 & 31.4 & 132 \\ -46.0 & -21.8 & 24.7 & 132 \\ -46.4 & -31.0 & 15.9 & 132 \\ -46.9 & -39.7 & 7.1 & 132 \\ & & & \end{array}$




\section{References}

1. Baugh, R. J.; Trowbridge, C. G. J. Biol. Chem. 1972, 247, 7498.

2. Castro, M. J. M.; Anderson, S. Biochemistry 1996, 35, 11435-11446.

3. Fukada, H.; Takahashi, K.; Sturtevant, J. M. Biochemistry 1985, 24, 5109-5115.

4. Filfil, R.; Chalikian, T. V. J. Mol. Biol. 2003, 326, 1271-1288.

5. Takahashi, K.; Fukada, H. Biochemistry 1985, 24, 297-300.

6. Milos, M.; Schaer, J.-J.; Comte, M.; Cox, J. A. J. Biol. Chem. 1988, 263, 9218-9222.

7. Kelley, R. F.; O’Connell, M. P.; Carter, P.; Presta, L.; Eigenbrot, C.; Covarrubias, M.; Snedecor, B.; Bourell, J. H.; Vetterlein, D. Biochemistry 1992, 31, 5434-5441.

8. $\quad$ Hibbits, K. A.; Gill, D. S.; Willson, R. C. Biochemistry 1994, 33, 3584-3590.

9. Tsumoto, K.; Ueda, Y.; Maenaka, K.; Watanabe, K.; Ogasahara, K.; Yutani, K.; Kumagai, I. J. Biol. Chem. 1994, 269, 28777-28782

10. Yokota, A.; Tsumoto, K.; Shiroishi, M.; Kondo, H.; Kumagai, I. J. Biol. Chem. 2003, 278, 5410-5418.

11. Bhat, T. N.; Bentley, G. A.; Boulet, G.; Greene, M. I.; Tello, D.; Dall'Acqua, W.; Souchon, H.; Schwarz, F. P.; Mariuzza, R. A.; Poljak, R. J. Proc. Nat. Acad. Sci. U.S.A. 1994, 91, 1089-1093.

12. Schwarz, F. P.; Tello, D.; Goldbaum, F. A.; Mariuzza, R. A.; Poljak, R. J. Eur. J. Biochem. 1995, 228, 388-394.

13. Tello, D.; Eisenstein, E.; Schwarz, F. P.; Goldbaum, F. A.; Fields, B. A.; Mariuzza, R. A.; Poljak, R. J. J. Mol. Recognit. 1994, 7, 57-62

14. Jelesarov, I.; Bosshard, H. R. Biochemistry 1994, 33, 13321-13328

15. Evans, L. J. A.; Cooper, A.; Lakey, J. H. J. Mol. Biol. 1996, 255, 559-563.

16. Martinez, J. C.; Filimonov, V. V.; Mateo, P. L.; Schreiber, G.; Fersht, A. R. Biochemistry 1995, 34, $5224-5233$.

17. Kelley, R. F.; Costas, K. E.; O’Connell, M. P.; Lazarus, R. A. Biochemistry 1995, 34, 10383'-10392.

18. Kresheck, G. C.; Vitello, L. B.; Erman, J. E. Biochemistry 1995, 34, 8398-8405.

19. Morar, A. S.; Pielak, G. J. Biochemistry 2002, 41, 547-551.

20. McLean, M. A.; Sligar, S. G. Biochem. Biophys. Res. Commun. 1995, 215, 316-320.

21. Murphy, K. P.; Freire, E.; Paterson, Y. Proteins 1995, 21, 83-90.

22. Raman, C. S.; Allen, M. J.; Nall, B. T. Biochemistry 1995, 34, 5831-5838.

23. Li, J.; Swanson, R. V.; Simon, M. I.; Weis, R. M. Biochemistry 1995, 34, 14626-.

24. Johanson, K.; Appelbaum, E.; Doyle, M.; Hensley, P.; Zhao, B.; Abdel-Meguid, S. S.; Young, P.; Cook, R.; Carr, S.; Matico, R.; Cusimano, D.; Dul, E.; Angelichio, M.; Brooks, I.; Winborne, E.; McDonnell, P.; Morton, T.; Bennett, D.; Sokoloski, T.; McNulty, D.; Rosenberg, M.; Chaiken, I. J. Biol. Chem. 1995, 270, 9459-9471.

25. Philo, J. S.; Aoki, K. H.; Arakawa, T.; Narhi, L. O.; Wen, J. Biochemistry 1996, 35, 1681-1691.

26. Pearce, K. H., Jr.; Ultsch, M. H.; Kelley, R. F.; de Vos, A. M.; Wells, J. A. Biochemistry 1996, 36, $10300-10307$.

27. Chauvin, F.; Fomenkov, A.; Johnson, C. R.; Roseman, S. Proc. Nat. Acad. Sci. U.S.A. 1996, 93, 7028-7031.

28. Philo, J. S.; Wen, J.; Wypych, J.; Schwartz, M. G.; Mendiaz, E. A.; Langley, K. E. J. Biol. Chem. 1996, 271, 6895-6902.

29. Lee, C. H.; Leung, B.; Lemmon, M. A.; Zheng, J.; Cowburn, D.; Kuriyan, J.; Saksela, K. EMBO J. 1995, $14,5006-5015$.

30. Renzoni, D. A.; Pugh, D. J. R.; Siligardi, G.; Das, P.; Morton, C. J.; Rossi, C.; Waterfield, M. D.; Campbell, I. D.; Ladbury, J. E. Biochemistry 1996, 35, 15646-15653.

31. Baker, B. M.; Murphy, K. P. J. Mol. Biol. 1997, 268, 557-569.

32. Aoki, K.; Taguchi, H.; Shindo, Y.; Yoshida, M.; Ogasahara, K.; Yutani, K.; Tanaka, N. J. Biol. Chem. 1997, 272, 32158-32162. 
33. Myszka, D. G.; Sweet, R. W.; Hensley, P.; Brigham-Burke, M.; Kwong, P. D.; Hendrickson, W. A.; Wyatt, R.; Sodroski, J.; Doyle, M. L. Proc. Nat. Acad. Sci. U.S.A. 2000, 97, 9026-9031.

34. Jung, H.-I.; Cooper, A.; Perham, R. N. Biochemistry 2002, 41, 10446-10453.

35. Buddai, S. K.; Toulokhonova, L.; Bergum, P. W.; Vlasuk, G. P.; Krishnaswamy, S. J. Biol. Chem. 2002, $277,26689-26698$.

36. Lukasik, S. M.; Zhang, L.; Corpora, T.; Tomanicek, S.; Li, Y.; Kundu, M.; Hartman, K.; Liu, P. P.: Laue, T. M.; Biltonen, R. L.; Speck, N. A.; Bushweller, J. H. Nature Struct. Mol. Biol. 2002, 9, 674-679.

37. Flatman, R.; McLauchlan, W. R.; Juge, N.; Furniss, C.; Berrin, J.-G.; Hughes, R. K.; Manzanares, P.; Ladbury, J. E.; O’Brien, R.; Williamson, G. Biochem. J. 2002, 365, 773-781.

38. Gell, D.; Kong, Y.; Eaton, S. A.; Weiss, M. J.; Mackay, J. P. J. Biol. Chem. 2002, 277, 40602-40609.

39. Girard, M.; Turgeon, S. L.; Gauthier, S. F. J. Agric. Food Chem. 2003, 51, 4450-4455.

40. Nielsen, P. K.; Bonsager, B. C.; Berland, C. R.; Sigurskjold, B. W.; Svensson, B. Biochemistry 2003, 42, $1478-1487$.

41. Baerga-Ortiz, A.; Bergqvist, S.; Mandell, J. G.; Komives, E. A. Protein Sci. 2004, 13, 166-176.

42. Zhou, Y.-L.; Liao, J.-M.; Du, F.; Liang, Y. Thermochim. Acta 2005, 426, 173-178.

43. Kouadio, J.-L. K.; Horn, J. R.; Pal, G.; Kossiakoff, A. A. J. Biol. Chem. 2005, 280, 25524-25532.

44. Keeble, A. H.; Kirkpatrick, N.; Shimizu, S.; Kleanthous, C. Biochemistry 2006, 45, 3243-3254.

45. Hegde, S. S.; Dam, T. K.; Brewer, C. F., Blanchard, J. S. Biochemistry 2002, 41, 7519-7527.

46. Krum, J. G.; Ellsworth, H.; Sargeant, R. R.; Rich, G.; Ensign, S. A. Biochemistry 2002, 41, 5005-5014.

47. Kwon, K.; Streaker, E. D.; Beckett, D. Protein Sci. 2002, 11, 558-570.

48. Saboury, A. A.; Divsalar, A.; Jafari, G. A.; Moosavi-Movahedi, A. A.; Housaindokht, M. R.; Hakimelahi, G. H. J. Biochem. Mol. Biol. 2002, 35, 302-305.

49. Saveanu, C.; Miron, S.; Borza, T.; Craescu, C. T.; Labesse, G.; Gagyi, C.; Popescu, A.; Schaeffer, F.; Namane, A.; Laurent-Winter, C.; Barzu, O.; Gilles, A.M. Protein Sci. 2003, 11, 2551-2560.

50. Lafitte, D.; Lamour, V.; Tsvetkov, P. O.; Makarov, A. A.; Klich, M.; Deprez, P.; Moras, D.; Briand, C.; Gilli, R. Biochemistry 2002 , 41, 7217-7223.

51. Ohtaka, H.; Velazquez-Campoy, A.; Xie, D.; Preire, E. Protein Sci. 2002, 11, 1908-1916.

52. Ambrosi, M.; Cameron, N. R.; Davis, B. G.; Stolnik, S. Org. Biomol. Chem. 2005, 3, 1476-1480.

53. Barratt, E.; Bingham, R. J.; Warner, D. J.; Laughton, C. A.; Phillips, S. E. V.; Homans, S. W. J. Am. Chem. Soc. 2005, 127, 11827-11834.

54. Brogan, A. P.; Widger, W. R.; Bensadek, D.; Riba-Garcia, I.; Gaskell, S. J.; Kohn, H. J. Am. Chem. Soc. 2005, 127, 2741-2751

55. Brown, P. H.; Beckett, D. Biochemistry 2005, 44, 3112-3121.

56. Dam, T. K.; Oscarson, S.; Roy, R.; Das, S. K.; Page, D.; Macaluso, F.; Brewer, C. F. J. Biol. Chem. 2005, 280, 8640-8646

57. Fielding, L.; Rutherford, S.; Fletcher, D. Magn. Reson. Chem. 2005, 43, 463-470.

58. Guazzaroni, M. A. E.; Krell, T.; Felipe, A.; Ruiz, R.; Meng, C. X.; Zhang, X. D.; Gallegos, M. T.; Ramos, J. L. J. Biol. Chem. 2005, $280,20887-20893$.

59. Johansson, J. S.; Manderson, G. A.; Ramoni, R.; Grolli, S.; Eckenhoff, R. G. FEBS Journal 2005, $272,573-581$.

60. Kedracka-Krok, S.; Gorecki, A.; Bonarek, P.; Wasylewski, Z. Biochemistry 2005, 44, 1037-1046.

61. Pereira, M. T.; Silva-Alves, J. M.; Martins-Jose, A.; Lopes, J. C. D.; Santoro, M. M. Brazil. J. Med.Biol. Res. 2005, 38, 1593-1601.

62. Sharrow, S. D.; Edmonds, K. A.; Goodman, M. A.; Novotny, M. V.; Stone, M. J. Protein Sci. 2005, 14, $249-256$.

63. Bingham, R. J.; Findlay, J. B. C.; Hsieh, S. Y.; Kalverda, A. P.; Kjeliberg, A.; Perazzolo, C.; Phillips, S. E. V.; Seshadri, K.; Trinh, C. H.; Turnbull, W. B.; Bodenhausen, G.; Homans, S. W. J. Am. Chem. Soc. 2004, 126, 1675-1681.

64. Crump, M. P.; Ceska, T. A.; Spyracopoulos, L.; Henry, A.; Archibald, S. C.; Alexander, R.; Taylor, R. J.; Findlow, S. C.; O'Connell, J.; Robinson, M. K.; Shock, A. Biochemistry 2004, 43, 2394-2404.

65. Gloster, T. M.; Macdonald, J. M.; Tarling, C. A.; Stick, R. V.; Withers, S. G.; Davies, G. J. J. Biol. Chem. 2004, $279,49236-49242$. 
66. Gotmar, G.; Ozen, C.; Serpersu, E.; Guiochon, G. J. Chromatogr. A 2004, 1046, 49-53.

67. King, N. M.; Prabu-Jeyabalan, M.; Nalivaika, E. A.; Wigerinck, P.; de Bethune, M. P.; Schiffer, C. A. J. Virol. 2004, 78, 12012-12021.

68. Kolobe, D.; Sayed, Y.; Dirr, H. W. Biochem. J. 2004, 382, 703-709.

69. Liu, R. Y.; Meng, Q. C.; Xi, J.; Yang, J. S.; Ha, C. E.; Bhagavan, N. V.; Eckenhoff, R. G. Biochem. J. 2004, $380,147-152$.

70. Ozen, C.; Serpersu, E. H. Biochemistry 2004, 43, 14667-14675.

71. Pey, A. L.; Thorolfsson, M.; Teigen, K.; Ugarte, M.; Martinez, A. J. Am. Chem. Soc. 2004, 126, 13670-13678.

72. Protasevich, II; Brouillette, C. G.; Snow, M. E.; Dunham, S.; Rubin, J. R.; Gogliotti, R.; Siegel, K. Biochemistry 2004, 43, $13380-13389$.

73. Sawas, A. H.; Pentyala, S. N.; Rebecchi, M. J. Biochemistry 2004, 43, 12675-12685.

74. Stolt, P. C.; Vardar, D.; Blacklow, S. C. Biochemistry 2004, 43, 10979-10987.

75. Taboada, P.; Fernandez, Y.; Mosquera, V. Biomacromolecules 2004, 5, 2201-2211.

76. Yassin, Z.; Ortiz-Salmeron, E.; Garcia-Maroto, F.; Baron, C.; Garcia-Fuentes, L. Biochim. Biophys. Acta-Proteins \& Proteomics 2004, 1698, 227-237.

77. Deniau, C.; Gilli, R.; Izadi-Pruneyre, N.; Letoffe, S.; Delepierre, M.; Wandersman, C.; Briand, C.; Lecroisey, A. Biochemistry 2003, 42, 10627-10633.

78. Dignam, J. D.; Nada, S.; Chaires, J. B. Biochemistry 2003, 42, 5333-5340.

79. Laurine, E.; Lafitte, D.; Gregoire, C.; Seree, E.; Loret, E.; Douillard, S.; Michel, B.; Briand, C.; Verdier, J. M. J. Biol. Chem. 2003, 278, $29979-29986$.

80. Schon, A.; Ingaramo, M. D.; Freire, E. Biophys. Chem. 2003, 105, 221-230.

81. Talhout, R.; Villa, A.; Mark, A. E.; Engberts, J. J. Am. Chem. Soc. 2003, 125, 10570-10579.

82. Torigoe, H.; Nakayama, T.; Imazato, M.; Shimada, I.; Arata, Y.; Sarai, A. J. Biol. Chem. 1995, $270,22218-22222$.

83. Bazarsuren, A.; Grauschopf, U.; Wozny, M.; Reusch, D.; Hoffmann, E.; Schaefer, W.; Panzner, S.; Rudolph, R. Biophys. Chem. 2002, 96, 305-318.

84. Akhter, S.; Vignini, A.; Wen, Z.; English, A.; Wang, P. G.; Mutus, B. Proc. Natl. Acad. Sci. U. S. A. 2002, 99, $9172-9177$.

85. Buddai, S. K.; Toulokhonova, L.; Bergum, P. W.; Vlasuk, G. P.; Krishnaswamy, S. J. Biol. Chem. 2002, 277, 26689-26698.

86. Censarek, P.; Beyermann, M.; Koch, K.-W. Biochemistry 2002, 41, 8598-8604.

87. Davidson, J. P.; Lubman, O.; Rose, T.; Waksman, G.; Martin, S. F. J. Am. Chem. Soc. 2002, 124, $205-215$.

88. Gribenko, A. V.; Guzman-Casado, M.; Lopez, M. M.; Makhatadze, G. I. Protein Sci. 2002, 11, 1367-1375.

89. Jung, H.-I.; Bowden, S. J.; Cooper, A.; Perham, R. N. Protein Sci. 2002, 11, 1091-1100.

90. Yan, K. S.; Kuti, M.; Yan, S.; Mujtaba, S.; Farooq, A.; Goldfarb, M. P.; Zhou, M.-M. J. Biol. Chem. 2002, 277, 17088-17094

91. Babon, J. J.; Yao, S. G.; DeSouza, D. P.; Harrison, C. F.; Fabri, L. J.; Liepinsh, E.; Scrofani, S. D.; Baca, M.; Norton, R. S. FEBS J. 2005, 272, 6120-6130.

92. Banerjee, Y.; Mizuguchi, J.; Iwanaga, S.; Kini, R. M. J. Biol. Chem. 2005, 280, 42601-42611.

93. Cliff, M. J.; Williams, M. A.; Brooke-Smith, J.; Barford, D.; Ladbury, J. E. J. Mol. Biol. 2005, 346, 717-732.

94. Andujar-Sanchez, M.; Smith, A. W.; Clemente-Jimenez, J. M.; Rodriguez-Vico, F.; Heras-Vazquez, F. J. L.; Jara-Perez, V.; Camara-Artigas, A. Biochemistry 2005, 44, 1174-1183.

95. Iram, S. H.; Cronan, J. E. J. Biol. Chem. 2005, 280, 32148-32156.

96. Ivancic, M.; Spuches, A. M.; Guth, E. C.; Daugherty, M. A.; Wilcox, D. E.; Lyons, B. A. Protein Sci. 2005, 14, 1556-1569.

97. Piszczek, G.; Rozycki, J.; Singh, S. K.; Ginsburg, A.; Maurizi, M. R. J. Biol. Chem. 2005, 280, 12221-12230.

98. Tsvetkov, P. O.; Ezraty, B.; Mitchell, J. K.; Devred, F.; Peyrot, V.; Derrick, P. J.; Barras, F.; Makarov, A. A.; Lafitte, D. Biochimie 2005, 87, 473-480.

99. Udugamasooriya, G.; Saro, D.; Spaller, M. R. Org. Lett. 2005, 7, 1203-1206.

100. Wylie, G. P.; Rangachari, V.; Bienkiewicz, E. A.; Marin, V.; Bhattacharya, N.; Love, J. F.; Murphy, J. R.; Logan, T. M. Biochemistry 2005, 44, 40-51.

101. Censarek, P.; Beyermann, M.; Koch, K. W. FEBS Lett. 2004, 577, 465-468.

102. Cobos, E. S.; Pisabarro, M. T.; Vega, M. C.; Lacroix, E.; Serrano, L.; Ruiz-Sanz, J.; Martinez, J. C. J. Mol. Biol. 2004, $342,355-365$.

103. Fernando, H.; Chin, C.; Rosgen, J.; Rajarathnam, K. J. Biol. Chem. 2004, 279, 36175-36178. 
104. Ferreon, J. C.; Hilser, V. J. Biochemistry 2004, 43, 7787-7797.

105. Gao, G. H.; Prutzman, K. C.; King, M. L.; Scheswohl, D. M.; DeRose, E. F.; London, R. E.; Schaller, M. D.; Campbell, S. L. J. Biol. Chem. 2004, 279, 8441-8451.

106. Katragadda, M.; Morikis, D.; Lambris, J. D. J. Biol. Chem. 2004, 279, 54987-54995.

107. Li, T.; Saro, D.; Spaller, M. R. Bioorg. Med. Chem. Lett. 2004, 14, 1385-1388.

108. Palencia, A.; Cobos, E. S.; Mateo, P. L.; Martinez, J. C.; Luque, I. J. Mol. Biol. 2004, 336, 527-537.

109. Saro, D.; Klosi, E.; Paredes, A.; Spaller, M. R. Org. Lett. 2004, 6, 3429-3432.

110. Zhao, K. H.; Chai, X. M.; Marmorstein, R. J. Mol. Biol. 2004, 337, 731-741.

111. Andujar-Sanchez, M.; Clemente-Jimenez, J. M.; Las Heras-Vazquez, F. J.; Rodriguez-Vico, F.; Camara-Artigas, A.; Jara-Perez, V. Int. J. Biol. Macromol. 2003, 32, 77-82.

112. Ortiz-Salmeron, E.; Nuccetelli, M.; Oakley, A. J.; Parker, M. W.; Lo Bello, M.; Garcia-Fuentes, L. J. Biol. Chem. 2003, 278, 46938-46948.

113. Bitto, E.; McKay, D. B. J. Biol. Chem. 2003, 278, 49316-49322.

114. Welfle, K.; Misselwitz, R.; Hohne, W.; Welfle, H. J. Mol. Recognit. 2003, 16, 54-62.

115. Murphy, K. P.; Xie, D.; Garcia, K. C.; Amzel, L. M.; Freire, E. Proteins 1993, 15, 113-120.

116. Gomez, J.; Freire, E. J. Mol. Biol. 1995, 252, 337-350.

117. Page, J. D.; You, J.-L.; Harris, R. B.; Colman, R. W. Arch. Biochem. Biophys. 1994, 314, 159-164.

118. Lemmon, M. A.; Ladbury, J. E.; Mandiyan, V.; Zhou, M.; Schlessinger, J. J. Biol. Chem. 1994, 269, 31653-31658.

119. Renzoni, D. A.; Pugh, D. J. R.; Siligardi, G.; Das, P.; Morton, C. J.; Rossi, C.; Waterfield, M. D.; Campbell, I. D.; Ladbury, J. E. Biochemistry 1996, 35, 15646-15653.

120. Ladbury, J. E.; Lemmon, M. A.; Zhou, M.; Green, J.; Botfield, M. C.; Schlessinger, J. Proc. Nat. Acad. Sci. U.S.A. 1995, 92, 3199-3203.

121. Ladbury, J. E.; Hensmann, M.; Panayotou, F.; Campbell, I. D. Biochemistry 1996, 35, 11062-11069.

122. Mandiyan, V.; O’Brien, R.; Zhou, M.; Margolis, B.; Lemmon, M. A.; Sturtevant, J. M.; Schlessinger, J. J. Biol. Chem. 1996, 271 , 4770-4775.

123. Leder, L.; Berger, C.; Bornhauser, S.; Wendt, H.; Ackerman, F.; Jelesarov, I.; Bosshard, H. R. Biochemistry 1995, 34, 16509-16518.

124. Milos, M.; Schaer, J.-J.; Comte, M.; Cox, J. A. J. Biol. Chem. 1987, 262, 2746-2749.

125. Varadarajan, R.; Connelly, P. R.; Sturtevant, J. M.; Richards, F. M. Biochemistry 1992, 31, 1421-1426.

126. Weber, P. C.; Pantoliano, M. W.; Thompson, L. D. Biochemistry 1992, 31, 9350-9354.

127. Schmidt, T. G. M.; Koepke, J.; Frank, R.; Skerra, A. J. Mol. Biol. 1996, 255, 753-766.

128. Wu, J.; Li, J.; Li, G.; Long, D. G.; Weis, R. M. Biochemistry 1996, 35, 4984-4993.

129. Petrella, E. C.; Machesky, L. M.; Kaiser, D. A.; Pollard, T. D. Biochemistry 1996, 35, 16535-16543.

130. Jelesarov, I.; Bosshard, H. R. J. Mol. Biol. 1996, 263, 344-358.

131. Lin, Z.; Schwarz, F. P.; Eisenstein, E. J. Biol. Chem. 1995, 270, 1011-1014.

132. Smallshaw, J. E.; Georges, F.; Lee, J. S.; Waygood, E. B. Protein Eng. 1999, 12, 623-630. 